\title{
Groundwater Annual Status Report \\ for Fiscal Year 1998
}

\section{RECEIVED AUG 121999 OSTI}

\section{Los Alamos




\section{DISCLAIMER}

This report was prepared as an account of work sponsored by an agency of the United States Government. Neither the United States Government nor any agency thereof, nor any of their employees, make any warranty, express or implied, or assumes any legal liability or responsibility for the accuracy, completeness, or usefulness of any information, apparatus, product, or process disclosed, or represents that its use would not infringe privately owned rights. Reference herein to any specific commercial product, process, or service by trade name, trademark, manufacturer, or otherwise does not necessarily constitute or imply its endorsement, recommendation, or favoring by the United States Government or any agency thereof. The views and opinions of authors expressed herein do not necessarily state or reflect those of the United States Government or any agency thereof. 


\title{
DISCLAIMER
}

\author{
Portions of this document may be illegible \\ in electronic image products. Images are \\ produced from the best available original \\ document.
}


An Affirmative Action/Equal Opportunity Employer

This report was prepared as an account of work sponsored by an agency of the United States Government. Neither The Regents of the University of California, the United States Government nor any agency thereof, nor any of their employees, makes any warranty, express or implied, or assumes any legal liability or responsibility for the accuracy, completeness, or usefulness of any information, apparatus, product, or process disclosed, or represents that its use would not infringe privately owned rights. Reference herein to any specific commercial product, process, or service by trade name, trademark, manufacturer, or otherwise, does not necessarily constitute or imply its endorsement, recommendation, or favoring by The Regents of the University of California, the United States Government, or any agency thereof. The views and opinions of authors expressed herein do not necessarily state or reflect those of The Regents of the University of California, the United States Government, or any agency thereof. Los Alamos National Laboratory strongly supports academic freedom and a

researcher's right to publish; as an institution, however, the Laboratory does not endorse the viewpoint of a publication or guarantee its technical correctness. 
LA-13598-SR

Status Report

Issued: April 1999

Groundwater Annual Status Report

for Fiscal Year 1998

C. L. Nylander

K. A. Bitner*

D. E. Broxton

G. L. Cole

B. M. Gallaher

A. S. Johnson**

D. Katzman

E. H. Keating

$P$. Longmire

S. G. McLin

K. I. Mullen

B. D. Newman

D. B. Rogers

A. K. Stoker ***

W. J. Stone

* Consultant at Los Alamos. Neptune \& Co., 4600-A Montgomery, Suite 100, Albuquerque, NM 87110

** Consultant at Los Alamos. Los Alamos Technical Associates, 1200 Trinity Drive, Los Alamos, NM 87544

** Consultant at Los Alamos. Science Applications, 122 Longview Drive, Los Alamos, NM 87544

\section{Los Alamos \\ NATIONAL LABORATORY \\ Los Alamos, New Mexico 87545}





\section{TABLE OF CONTENTS}

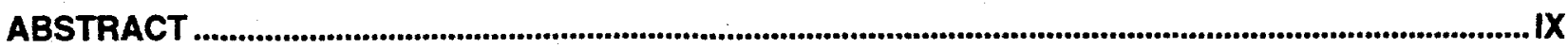

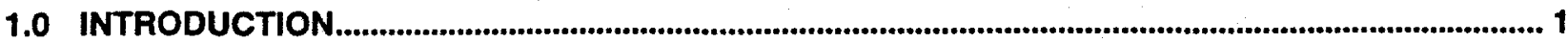

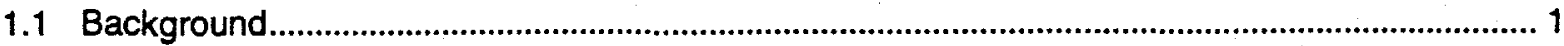

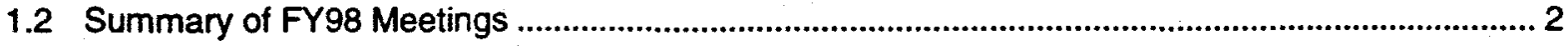

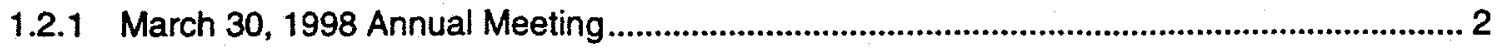

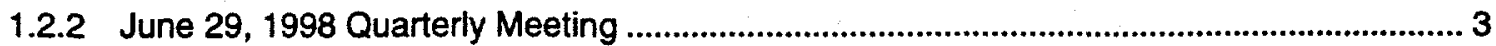

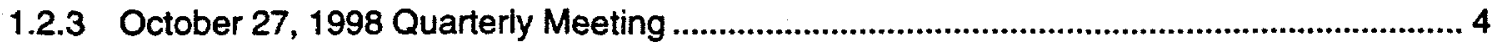

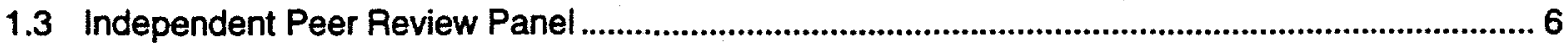

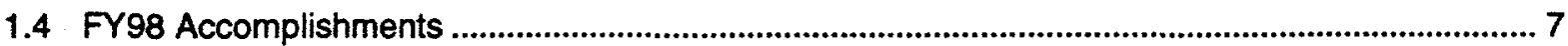

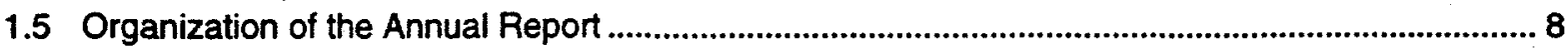

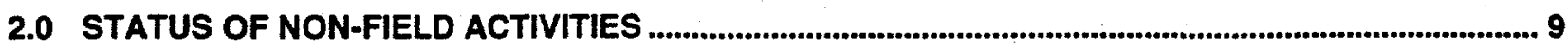

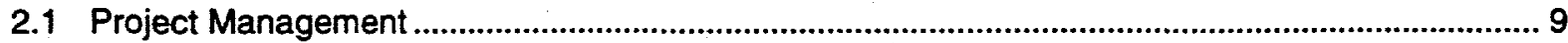

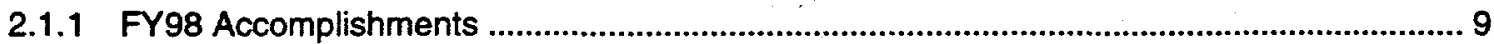

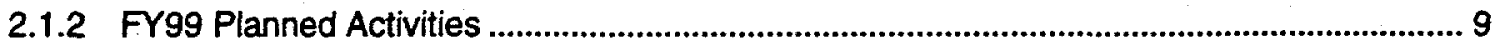

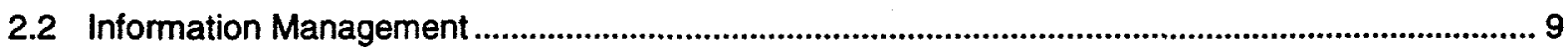

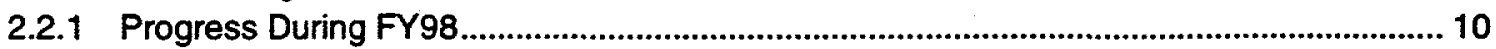

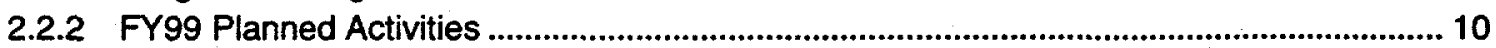

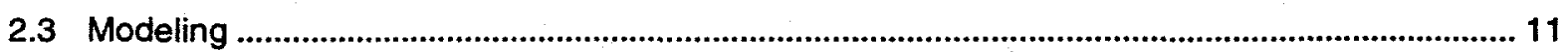

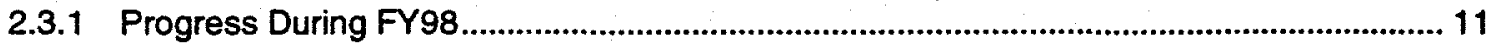

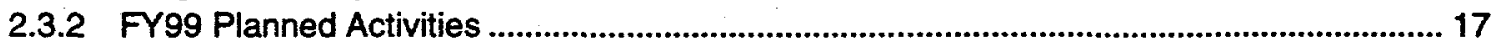

3.0 FY98 HYDROGEOLOGIC CONCEPTUAL MODEL (AGGREGATE 9) ........................................... 19

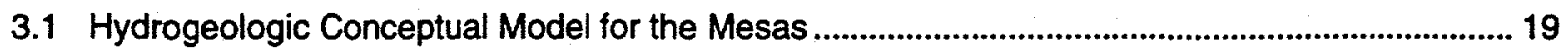

3.2 Hydrogeologic Conceptual Model for Alluvial Groundwater ....................................................... 20

3.3 Hydrogeologic Conceptual Model for Intermediate Perched Groundwater .................................... 23

3.4 Hydrogeologic Conceptual Model for the Regional Aquifer ...................................................... 25

3.5 FY98 Revisions to the Hydrogeologic Conceptual Model (Aggregate 9 Conceptual Model

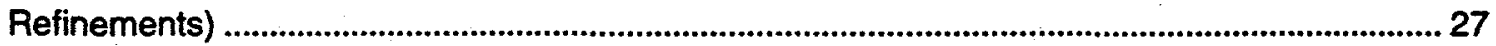

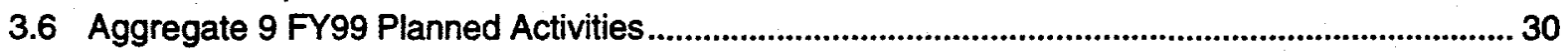

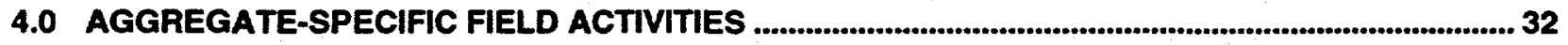

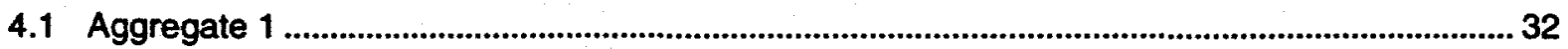

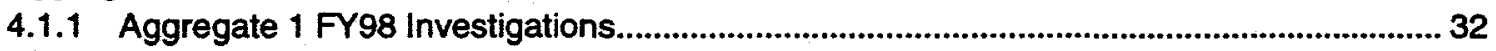

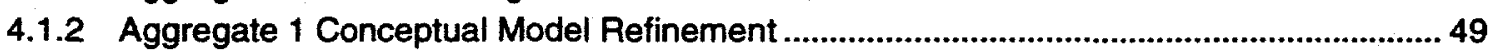

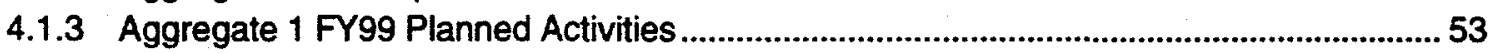

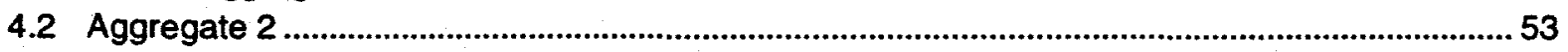

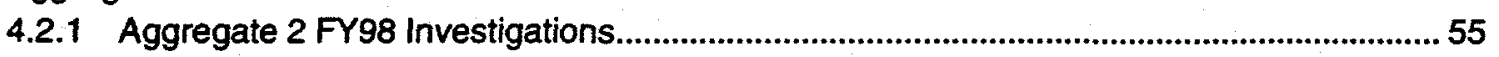

4.2.2 Aggregate 2 Conceptual Model Refinement ..................................................................56

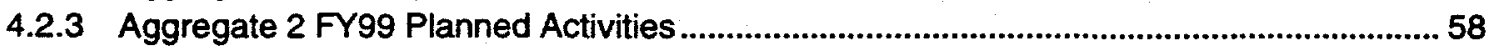

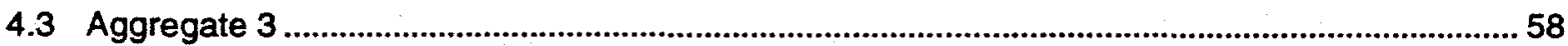

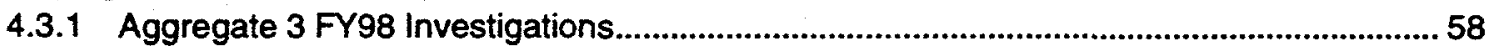

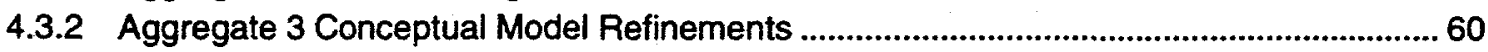

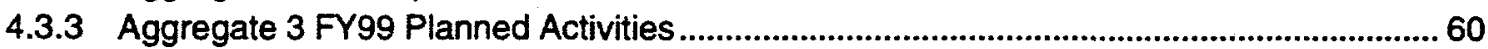

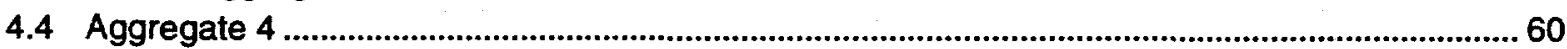

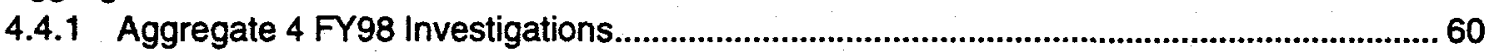

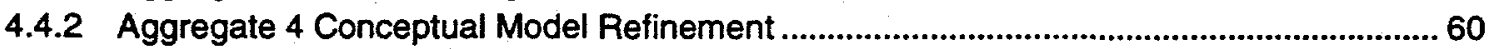

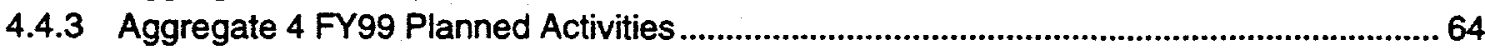




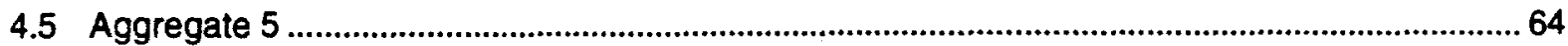

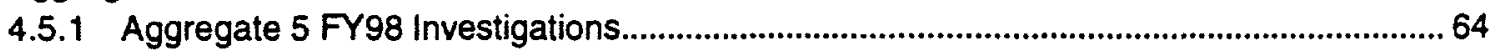

4.5.2 Aggregate 5 Conceptual Model Refinements ......................................................................6. 66

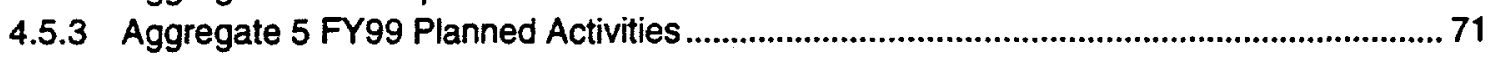

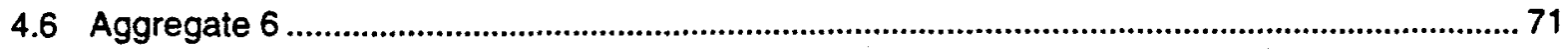

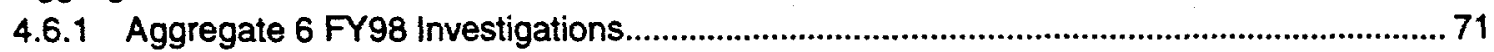

4.6.2 Aggregate 6 Conceptual Model Refinement ...................................................................... 71

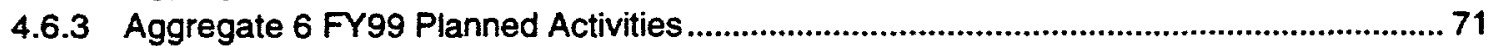

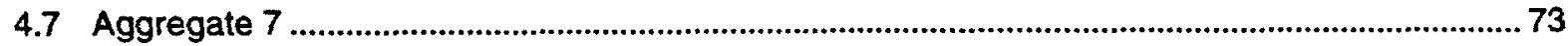

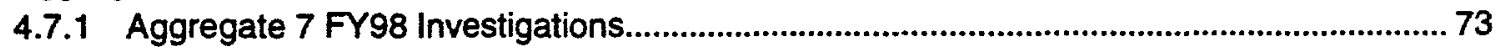

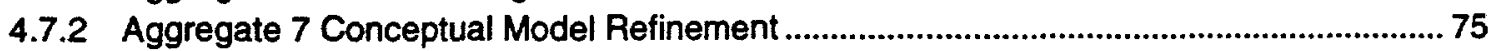

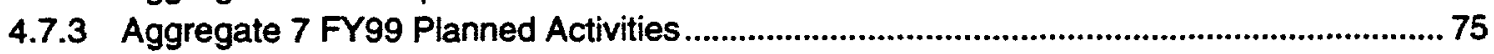

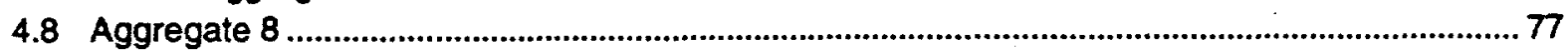

4.8.1 Aggregate 8 FY97 and FY98 Investigations ................................................................ 77

4.8.2 Aggregate 8 Conceptual Model Refinement................................................................ 77

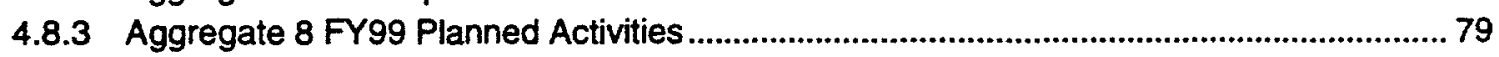

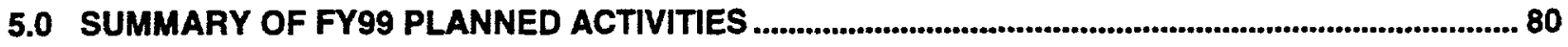

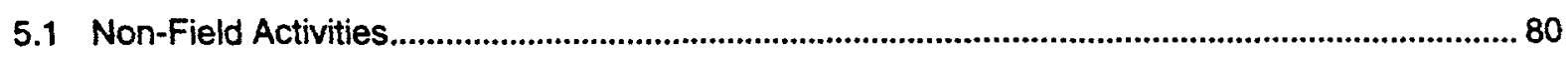

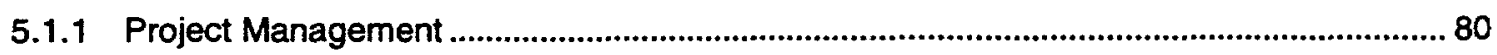

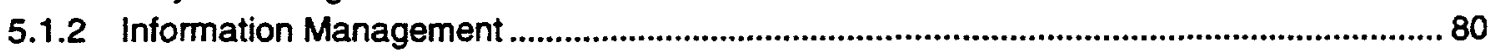

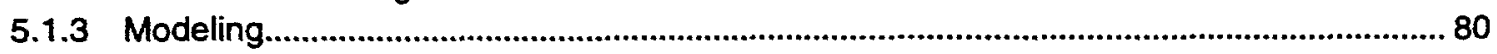

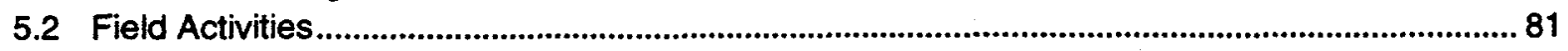

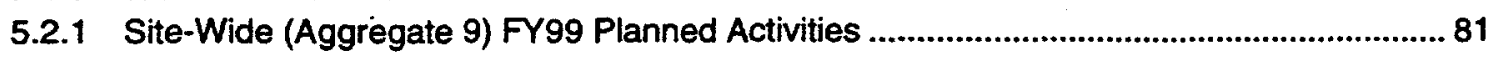

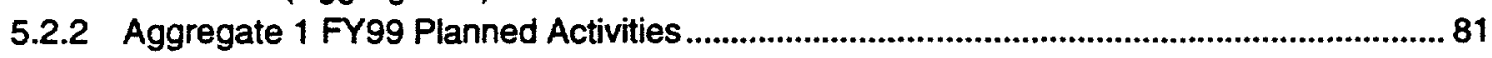

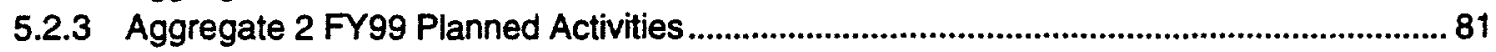

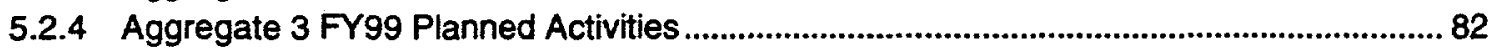

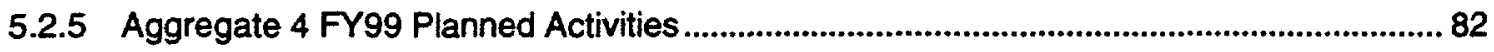

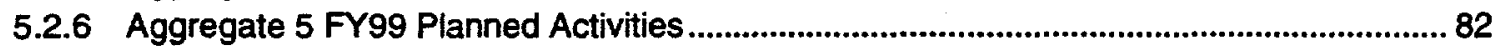

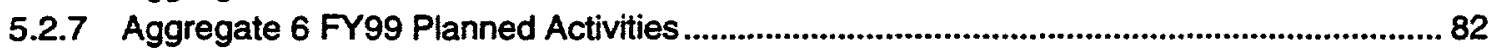

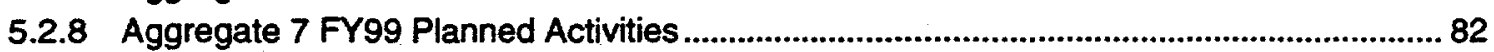

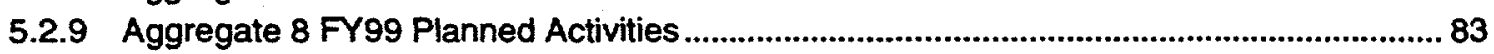

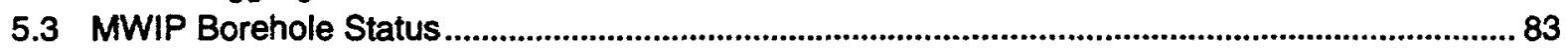

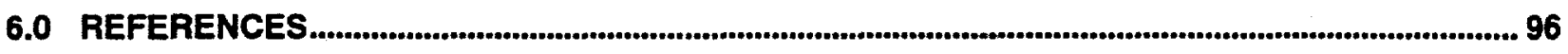

7.0 ANNUAL MEETING MINUTES AND ACTION ITEMS $\ldots \ldots \ldots \ldots$

\section{FIGURES}

Figure 3.2-1. Volume of shallow groundwater vs. annual streamflow loss and effluent discharge............ 21

Figure 4-1. Locations of aggregates and MWIP regional aquifer wells and proposed boreholes. ......... 33

Figure 4-2. Locations of aggregates and proposed MWIP alluvial wells. ................................................ 34

Figure 4-3. Locations of geologic cross sections. .................................................................................. 35

Figure 4.1-1. Potential release sites (PRSs) and proposed wells in Aggregate 1....................................36

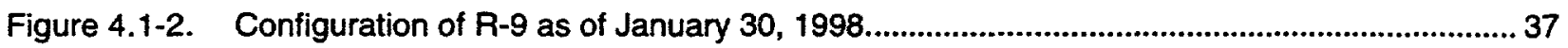

Figure 4.1-3. Water level and barometric pressure readings from boreholes $R-9$ and R-12 ................... 38

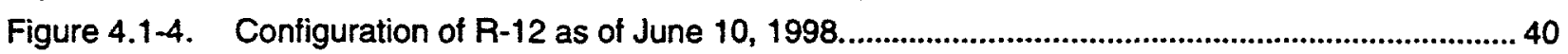


Figure 4.1-5. Wells installed in 1998 and other proposed well locations: western Los Alamos and Pueblo Canyons.

Figure 4.1-6. Wells installed in 1998 and other proposed well locations: central Los Alamos and Pueblo

Canyons.

Figure 4.1-7. Schematic cross section depicting conceptual model elements, R-9 results, and proposed regional aquifer wells for upper Los Alamos Canyon.

Figure 4.1-8. Schematic cross section depicting conceptual model elements and proposed regional aquifer wells for Pueblo Canyon.

Figure 4.2-1. PRSs and proposed wells in Aggregate 2.

Figure 4.2-2. Schematic cross section depicting conceptual model elements and proposed regional aquifer wells for Pajarito and Twomile canyons. .............................................................................5 57

Figure 4.3-1. PRSs and proposed wells in Aggregate 3. .59

Figure 4.3-2. Schematic cross section depicting conceptual model elements and proposed regional aquifer wells for Cañon de Valle and Water Canyon.

Figure 4.4-1. PRSs and proposed wells in Aggregate 4. 62

Figure 4.4-2. Schematic cross section depicting conceptual model elements and proposed regional aquifer wells for Ancho Canyon.

Figure 4.5-1. PRSs and proposed wells in Aggregate 5.

Figure 4.5-2. Plot showing geologic units, groundwater zones, proposed monitoring zones and distribution of key HE constituents in borehole R-25.

Figure 4.5-3. Deep boreholes showing constituents above background in water at TA-16. 68

Figure 4.5-4. Conceptual model elements at TA-16.

Figure 4.5-5. PRSs and proposed wells in Aggregate 6.

Figure 4.7-1. PRSs and proposed wells in Aggregate 7 .

Figure 4.7-2. Schematic cross section depicting conceptual model elements and proposed regional aquifer wells for Mortandad Canyon.

Figure 4.8-1. PRSs and proposed wells in Aggregate 8.

Figure 5.3-1. MWIP well completion schedule.

\section{TABLES}

Table 2.3-1. Status of FY98 Non-Field Activities 12

Table 4.1-1. Summary of Nitrogen Chemistry and Nitrogen Isotopes for Several Waters in Sandia Pueblo, Los Alamos Canyon, and TA-50 48

Table 4.7-1. Geologic Units Penetrated in Phase 1 at Borehole R-15.

\section{ACRONYMS}

$\begin{array}{ll}\text { bgs } & \text { below ground surface } \\ \text { BMP } & \text { best management practice } \\ \text { 2-D } & \text { two-dimensional } \\ \text { 3-D } & \text { three-dimensional } \\ \text { DLM } & \text { diffuse layer model } \\ \text { DNT } & \text { dinitrotoluene }\end{array}$




\begin{tabular}{|c|c|}
\hline DOE & Department of Energy \\
\hline DP & Defense Programs (DOE) \\
\hline DQO & data quality objective \\
\hline EEG & External Evaluation Group \\
\hline EES & Earth and Environmental Sciences (Division) \\
\hline EPA & Environmental Protection Agency \\
\hline ER & Environmental Restoration \\
\hline ESH & Environment, Safety, and Health (Division) \\
\hline ET & evapotranspiration \\
\hline FEHM & Finite Element Heat and Mass Transfer (code) \\
\hline FIMAD & Facility for Information Management, Analysis, and Display \\
\hline GIT & Groundwater Integration Team \\
\hline GWPMPP & Groundwater Protection Management Program Plan \\
\hline HE & high explosive \\
\hline HFO & hydrous ferric oxide \\
\hline$H M X$ & octahydro-1,3,5,7-tetranitro-1,3,5,7-tetrazine \\
\hline HRMB & Hazardous and Radioactive Materials Bureau (NMED) \\
\hline HSWA & Hazardous and Solid Waste Amendments (of 1984) \\
\hline HWPDB & Hydrogeologic Workplan database \\
\hline$K_{d}$ & distribution coefficient \\
\hline LANL & Los Alamos National Laboratory \\
\hline MCL & maximum contaminant level \\
\hline MDA & material disposal area \\
\hline MWIP & Monitoring Well Installation Project \\
\hline NMED & New Mexico Environment Department \\
\hline PA & performance assessment \\
\hline ppb & parts per billion \\
\hline ppm & parts per million \\
\hline PRS & potential release site \\
\hline QA & quality assurance \\
\hline RCRA & Resource Conservation and Recovery Act \\
\hline RDX & hexahydro-1,3,5-trinitro-1,3,5-triazine \\
\hline RFI & RCRA facility investigation \\
\hline SVOC & semivolatile organic compound \\
\hline SWSC & Sanitary Wastewater Systems Consolidation \\
\hline TA & technical area \\
\hline TAL & target analyte list \\
\hline TCA & trichloroethane \\
\hline TCE & trichloroethylene \\
\hline TNT & trinitrotoluene \\
\hline USGS & United States Geological Survey \\
\hline VCA & voluntary corrective action \\
\hline VOC & volatile organic compound \\
\hline
\end{tabular}




\title{
GROUNDWATER ANNUAL STATUS REPORT \\ for \\ FISCAL YEAR 1998
}

\author{
by \\ C. L. Nylander, K. A. Bitner, D. E. Broxton, G. L. Cole, B. M. Gallaher, A. S. Johnson, D. Katzman, \\ E. H. Keating, P. Longmire, S. G. McLin, B. D. Newman, K. I. Mullen, D. B. Rogers, A. K. Stoker, and \\ W. J. Stone
}

\begin{abstract}
Groundwater protection activities and hydrogeologic characterization studies are conducted at LANL annually. A summary of fiscal year 1998 results and findings shows increased understanding of the hydrogeologic environment beneath the Pajarito Plateau and significant refinement to elements of the LANL Hydrogeologic Conceptual Model pertaining to areas and sources of recharge to the regional aquifer. Modeling, drilling, monitoring, and data collection activities are proposed for fiscal year 1999.
\end{abstract}




\subsection{INTRODUCTION}

This second Groundwater Annual Status Report is intended to provide the Department of Energy (DOE), the New Mexico Environment Department (NMED), and other interested stakeholders with a status of the groundwater protection and management activities performed during fiscal year 1998. This report summarizes changes made to the Los Alamos National Laboratory's (LANL's or Laboratory's) conceptual model of the hydrogeologic setting as a result of integrating data collected over the past year. It also provides a projection of activities to be performed in fiscal year 1999.

This document provides the status of the implementation of the Laboratory's Hydrogeologic Workplan and serves as a focal document for the annual stakeholder meeting held in March of each year. It is specifically written as a summary-level report and relies on information incorporated by reference and works-in-progress.

\subsection{Background}

The need to prepare this Annual Report comes from commitments made in the Groundwater Protection Management Program Plan (GWPMPP) (LANL, 1996) and the Hydrogeologic Workplan (LANL, 1998). The Laboratory has had groundwater programs in place since 1945. The early programs were focused on the need to develop reliable water supplies. Groundwater quality has been monitored through the environmental surveiliance program using existing test wells, water supply wells, and springs. Since the early 1990s, there has been an increased emphasis on understanding the hydrogeologic environment in order to more effectively protect and manage the groundwater resource.

The GWPMPP (approved by DOE in 1996) provides for submittal of an annual groundwater status report to DOE summarizing the status of groundwater protection activities listed in the GWPMPP. The GWPMPP was prepared in response to the DOE requirement to conduct operations in an environmentally safe manner. DOE Order 5400.1: "General Environmental Protection Program" establishes environmental protection requirements, authorities, and responsibilities for all DOE facilities (DOE 1990). The goal of this order is to ensure that operations at DOE facilities comply with all applicable environmental laws and regulations, executive orders, and departmental policies.

The Hydrogeologic Workplan (approved by NMED in 1998) commits the Laboratory to prepare an annual report to summarize the activities of the previous fiscal year and to make recommendations for the current fiscal year activities. The Hydrogeologic Workplan was prepared in response to the NMED request to prepare a hydrogeologic work plan to address the requirements of the Resource Conservation and Recovery Act (RCRA) and the Hazardous and Solid Waste Amendments of 1984 (HSWA) as detailed in the regulations and in the Laboratory's RCRA/HSWA permit. The Hydrogeologic Workplan is the implementing document for the GWPMPP and the Laboratory's institutional commitment to complete a hydrogeologic characterization program. It includes the installation of 32 regional aquifer wells, i.e., the Monitoring Well Installation Project (MWIP), and describes the data collection and analysis activities needed to characterize the hydrogeologic setting of the Laboratory as part of the Pajarito Plateau within the regional context of the Española basin. The need for characterization of the hydrogeologic setting beyond that already established by studies over the past 50 years has been recognized as a critical step in developing an effective monitoring program and in managing the groundwater resource.

This document serves as the annual status report for both the GWPMPP and the Hydrogeologic Workplan. Further, this document serves as the update mechanism for the scope and schedule in the Hydrogeologic Workplan. Specifically, the Hydrogeologic Workplan will not be revised; however, changes to the scope and schedule outlined in the workplan will be discussed with NMED in quarterly meetings 
and at an annual meeting. Those changes for which there is concurrence by all parties will be documented in this Annual Report and in the subsequent annual meeting minutes.

\subsection{Summary of FY98 Meetings}

Three meetings were held to discuss the groundwater characterization activities that occurred in FY98. The participants of the meetings were Laboratory staff involved in the activities, DOE representatives, and NMED representatives from the bureaus of Hazardous and Radioactive Materials (HRMB), Groundwater Quality, and DOE Oversight. A summary of each meeting and the points of agreement are provided in the following sections.

\subsubsection{March 30, 1998 Annual Meeting}

The notes from the March 30 Annual Meeting were issued with the final approved Hydrogeologic Workplan (LANL, 1998) on May 22, 1998. The topics covered included the Laboratory's approach to groundwater protection, and presentation of the material in the "Groundwater Annual Status Summany Report FY97." The non-field activities included geologic model development and a discussion of historical water quality data.

The significant field accomplishments included:

- $\quad$ Drilling and sampling of borehole R-9 in Aggregate 1;

- Confirmation of the conceptual model's prediction of recharge through the mesas by Area G performance assessment in Aggregate 2;

- Confirmation of the conceptual model's prediction of recharge through the mesas by chloride and oxygen isotopes at Technical Area (TA) -49 in Aggregate 3;

- Confirmation that perched zones in TA-16 are intermittent and localized, but tracer test showed breakthrough to a spring in 3 months indicating rapid travel times in Aggregate 5.

Proposed FY98 non-field activities included data management improvements, hydrologic modeling of the region (Española basin). Proposed FY98 field activities included drilling boreholes R-12 and R-25 and starting R-7.

The agreements and action items resulting from the discussions during the Annual Meeting were:

\section{Agreements}

- Schedule

$\begin{array}{ll}\text { R-12 } & \text { March 1998 } \\ \text { R-25 } & \text { July 1998 } \\ \text { R-7 } & \text { Oct 1998 } \\ 2 \text { intermediate wells } & \\ \text { in Mortandad Canyon } & \text { Fall 1998/FY99 } \\ \text { R-14 } & \text { Spring 1999 }\end{array}$


- Final locations of wells will be reviewed for possible use for compliance wells on well-by-well basis

- Involve state in evaluations for well completion and other changes in scope.

- Intermediate well (or multi-completion in perched zones) decisions will be made as well completion decisions are made and installed usually within one year of regional well completion.

- $\quad$ Analyze for volatile organic compounds (VOCs)/semivolatile organic compounds (SVOCs) when sources are present, not in every sample. Use analysis from four quarters of sampling to define contaminants of concern.

- The data quality objectives (DQOs) will go through iteration when new data is available.

- $\quad$ Provide more detail in the Annual Report.

\section{Action Items}

- Schedule South Valley Westbay tour.

- $\quad$ Provide letter to NMED with request and justification to convert intermediate wells in LA Canyon to regional wells

\subsubsection{June 29, 1998 Quarterly Meeting}

The June 29 Quarterly Meeting is documented in notes issued in a memorandum from Charles Nylander of the Laboratory's Water Quality and Hydrology Group (Environment, Safety, and Health [ESH]-18) on July 31,1998 . The agenda included discussion of boreholes R-12, R-9, R-25, well installation priorities, TA-16 status, well drilling techniques, and the Annual Report. The geology and hydrology encountered in R-12 was discussed and the sampling was described. The major conclusions drawn from borehole R-12 are: (1) that the perched zone water is geochemically different from perched zones in borehole R-9, therefore the perched zones are laterally limited and probably do not extend beneath the mesas in this part of the Laboratory; and (2) the hydrologic setting of the regional aquifer in the northeast part of the Laboratory is different from that expected. The static water level for the regional aquifer is the same in both R-9 and R-12, and it is a different elevation than in the nearby water supply well. The integrated pressures in the water supply well raises the water level elevation by upward gradient.

Considerations for completing borehole R-9 at a deeper total depth were commented on. These include the location close to contaminant sources in Los Alamos Canyon and R-9 is not near existing deep wells as is borehole R-12, so the deeper information would be new data. Neither boreholes will be completed for another year due to budget constraints. Planned data collection versus actual data collection in the R9 and $R-12$ boreholes will be presented in the completion reports. The Hydrogeologic Workplan will be used as the basis of comparison.

Plans for borehole R-25 and expected costs were presented. Borehole R-25 will be much deeper than either $R-9$ or $R-12$ because the regional aquifer is expected to be at $1300 \mathrm{ft}$. The Barber drill rig will be used to drill R-25. The estimated cost of the well is $\$ 1.4$ million if it is single completion or $\$ 2.3$ million with stainless steel multiple completion. 
Switching the drilling order of borehole R-15 (in Mortandad Canyon) in place of borehole R-7 was discussed. This re-prioritization would be in response to data needed for the TA-50 Discharge Plan and to public concerns about Mortandad Canyon. There was consensus to move up the scheduled start date for R-15 at the expense of R-7, even though that will delay the completion of work in Los Alamos/Pueblo Canyon.

Updates of the results of tracer studies in TA-16 were described. Tracer studies suggest that fracture flow controls the contaminant distribution and saturation.

Well drilling techniques were discussed with a focus on reducing the cost of drilling the regional aquifer wells. Examples of well drilling techniques used at the Nevada Test Site'were provided based on interviews with Nevada Test Site personnel.

Suggestions were made regarding the Annual Report format. The Annual Report should provide the data that conclusions are based on. Referencing data is acceptable as long as the referenced data is readily accessible.

The major agreements and action items reached in the meeting were:

- Completion of boreholes R-9 and R-12 as wells will be approximately a year from now; a completion proposal with technical rationale will be presented at a future meeting.

- LANL will produce a comparison of the R-9 planned data collection versus actual data collection.

- R-15 will be drilled starting in October, 1998 and R-7 will be drilled in the spring of FY99.

- $\quad$ NMED HRMB will send comments on the "Groundwater Annual Status Summary Report FY97."

\subsubsection{October 27, 1998 Quarterly Meeting}

The second Quarterly Meeting was originally scheduled for the end of September but was postponed until the end of October to accommodate the participants' schedules. The notes from the October 27 Quarterly Meeting were distributed as a memo from Charles Nylander, ESH-18, dated December 15, 1998. The agenda for the meeting included discussion of R-25 progress, R-15 status, R-9 and R-12 completion, FY99 drilling plans, modeling task progress, use of existing test wells, results of peer review, status of database, and Annual Report.

Borehole R-25 encountered saturated conditions with a static water level at an elevation of $711 \mathrm{ft}$. This is considerably higher than the regional aquifer was expected, and it is unclear whether this saturation represents the regional aquifer or a perched zone. Core, cuttings, and a water sample from R-25 were field screened for high explosives ( $\mathrm{HE}$ ). The core and cuttings were negative, but the water sample did contain detectable HE. Analytical results from a fixed laboratory are pending.

Borehole R-15 is located in Mortandad Canyon. It was started in September with a hollow-stem auger drill rig. The borehole was down to $420 \mathrm{ft}$ where the hollow stem auger drill rig was no longer capable of drilling further. Continued drilling of R-15 will wait until the Barber rig is done at R-25.

The Laboratory's Groundwater Integration Team (GIT) Construction Subcommittee recommended that borehole $\mathrm{R}-\mathrm{9}$ be completed as a single screened interval in the regional aquifer. It will be completed in 
late winter/early spring. No recommendations have been made for $R-12$, but multiple completion is being contemplated.

Drilling plans for FY99 were described as follows:

Defense Programs (DP)

- $\quad$ Complete borehole R-25

- Drill and complete borehole R-5 in Pueblo Canyon

- Drill and complete borehole R-31 in Ancho Canyon

\section{Environmental Restoration (ER)}

- $\quad$ Complete borehole R-15

- Complete borehole R-9

- Install 2 alluvial wells in Pueblo Canyon and 2 alluvial wells in Mortandad Canyon

A draft report on regional (Española basin) flow modeling (see Keating et al., 1998) has been completed. Plans for FY99 include development of a high-resolution Pajarito Plateau model.

Existing test wells scheduled for plugging and abandonment will each be surveyed with the borehole camera. If a well is structurally sound and could be useful in the characterization or monitoring programs, it may be reworked and kept in service. It will be a well-by-well decision.

A peer review panel, independent of the Laboratory, has been formed to provide a review of the Hydrogeologic Workplan and the MWIP. The first meeting of the review panel was in August and the panel has submitted a report. (The peer review committee is described in Section 1.3 of this report).

A comprehensive database to support the groundwater and watershed programs is being developed. A steering committee is in place and a project leader has been hired. This data will be linked to ER data and will be accessible through a web site.

Annual Report is in preparation. It will be submitted to the state on or about January 15 . The peer review panel will review the Annual Report before it is submitted to the state.

Major points of agreement from the October 27 Quarterly Meeting were:

- $\quad$ NMED is concerned that intermediate perched groundwater zones are not receiving adequate attention in this groundwater characterization program. LANL has committed to addressing the intermediate perched groundwater zones.

- The completion of borehole R-9 with a single screen in the regional aquifer in the late winter/early spring.

- LANL committed to providing a list of "critical data needs" for modeling at the Annual Meeting in March.

- $\quad$ LANL committed to providing a more detailed presentation of the modeling to NMED in the near future, the date and time to be coordinated with John Young. 
- LANL will provide a copy of the External Peer Review Panel Report to NMED and the panel would like to have interactions with NMED.

- LANL committed to have a small group meeting with NMED to discuss the prioritization of the wells in December.

\subsection{Independent Peer Review Panel}

The GIT formed an External Evaluation Group (EEG) to provide an independent review of the GIT's implementation of the Laboratory's Hydrogeologic Workplan. The EEG consists of six members with diverse technical and professional backgrounds to provide a broad technical and managerial review of the Laboratory's Hydrogeologic Workplan activities and methods. The GIT plans to add two additional EEG members in FY99 to further strengthen this multi-disciplinary peer review group.

The EEG met August 17 and 18, 1998 at LANL for the first semi-annual review of activities proposed under the Hydrogeologic Workplan. The EEG studied the written document, the "Groundwater Annual Status Summary Report FY97", and the response to a request for information from the NMED. The EEG also listened to a number of introductory and technical presentations, participated in a field trip to view aspects of the geologic setting, and visited a well site where drilling operations were in progress.

The EEG has committed to provide technical review of groundwater characterization activities for the planned 7-year duration of the project. The EEG will meet twice annually, generally in March (associated with the annual meeting) and August. The EEG will review documents and provide requested advice through the year. The EEG has appointed a chairperson (Dr. Robert Charles) that coordinates EEG meetings and serves as the focal point for communication with the EEG.

The EEG consists of the following members:

- Robert Charles, Ph.D.-Dr. Charles has a doctorate in Geology with a specialty in geochemistry. $\mathrm{He}$ also has a Master of Arts degree in Organizational Management, and has more than 25 years of experience in his disciplinary areas. Dr. Charles serves as Chair of the EEG.

- Jack Powers, P.E.-Mr. Powers is a drilling consultant with more than 45 years of world-wide professional drilling experience.

- John Butler, M.S.-Mr. Butler has a Master of Science degree in Chemistry and 25 years of experience working for federal agencies, international agencies, and private companies. He has specialized in environmental economics since 1980.

- Robert Powell, M.S.-Mr. Powell has a Master of Science degree in Environmental Science and 25 years of experience and 33 groundwater-related publications. Mr. Powell has expertise in the area of low-flow groundwater sampling.

- $\quad$ Elizabeth Anderson, Ph.D.-Dr. Anderson has a doctorate degree in inorganic chemistry and more than 20 years of experience in health and environmental science. Dr. Anderson is a nationally renowned expert on risk assessment and established the major national risk assessment programs at the Environmental Protection Agency. 
- David Schafer, M.S.-Mr. Schafer is employed by Geraghty \& Miller and has 25 years of experience focused on computer modeling using numerical models, analytic element models, and proprietary analytical models that he has developed.

The major conclusions of the EEG's report, titled "Semi-Annual Report, Groundwater Integration Team External Evaluation Group Los Alamos National Laboratory" (EEG, 1998) are:

- The Hydrogeologic Workplan is thorough and well integrated with other on-going Laboratory programs and Laboratory staff have formed a productive team to accomplish the work.

- Relationships among LANL, DOE, and NMED appear to be improving, but continued frequent, detailed, and consistent communication efforts must be maintained to foster further improvement. Representatives of NMED were requested to attend the next semi-annual meeting.

- Reach a timely agreement with NMED on maximum contaminant levels (MCLs) and alternate contaminant levels.

- Knowledge of contaminant transport through the intermediate perched zones will be necessary. Although the focus is on the regional aquifer now, further examination of the intermediate perched zones in the future is recommended.

- The drilling methods and equipment are paramount to obtaining the information necessary to meet the DQOs in the Hydrogeologic Workplan. Although the drilling costs for the first two wells were high, the selected drilling technologies are correct and appropriate. However, the costs should be benchmarked against similar activities.

- Development of a comprehensive database should be a high priority.

- A second drilling crew should be trained and used to relieve the existing 3-person crew.

- Recommend metal fittings for well completion rather than PVC.

- Modeling should be concurrent with the well drilling/data collection and should be used to inform the decisions of how many more wells and where they are located.

\subsection{FY98 Accomplishments}

This section is intended to provide a concise list of FY98 groundwater activity accomplishments. Section 5.0 describes the ER Project-funded wells that are planned for FY99 based on the expected funding profile. More detailed descriptions of these activities are contained in the referenced sections.

- Drilled borehole R-12 in Sandia Canyon to the regional aquifer; collected cuttings, core, and water samples, and completed analyses of collected samples (Aggregate 1, Section 4.1)

- $\quad$ Drilled borehole R-25 near Cañon de Valle, collected cuttings, core, and water samples (Aggregate 5, Section 4.5)

- $\quad$ Started drilling borehole R-15 in Mortandad Canyon (Aggregate 7, Section 4.7)

- Installed alluvial wells PAO-2.5, PAO-3, PAO-5N, and PAO-5S (Aggregate 1, Section 4.1) 
- Completed a regional-scale hydrologic model using the Finite Element Heat and Mass Transfer (FEHM) code. This modeling effort is documented in a draft report by Keating et al. (1998) (Section 2.3)

- $\quad$ Formed an independent peer review panel to provide broad-based, multi-disciplinary assessments of the Hydrogeologic Workplan activities. The results of the first semi-annual peer review are documented in "Semi-Annual Report, Groundwater Integration Team External Evaluation Group, Los Alamos National Laboratory" (EEG, 1998) (Section 1.3).

- $\quad$ Completed a user needs assessment for the comprehensive groundwater database (Section 2.2).

\subsection{Organization of the Annual Report}

Both the GWPMPP and the Hydrogeologic Workplan describe data collection and analysis activities. These activities consist of both non-field and field activities. Non-field activities include tasks such as project management, data management, and computer modeling. Field activities include some that are regional in scale (e.g., sample all springs) and some that are specific to particular geographic areas, referred to as aggregates in the Hydrogeologic Workplan.

The status of the non-field activities is described in Section 2.0 of this report. Section 3.0 provides the current updates to the conceptual model based on the year's studies and completed activities. The results of the field activities are presented in Section 4.0 and Section 5.0. Section 4.0 provides discussion of the aggregate-specific studies and findings. Section 5.0 contains a summary of activities proposed for FY99. Section 6.0 provides the bibliographic information and Section 7.0 is a placeholder for the annual meeting minutes and action items that will be distributed during the week following the annual meeting. 


\subsection{STATUS OF NON-FIELD ACTIVITIES}

Non-field activities fall into one of three categories: project management, information management, and modeling.

\subsection{Project Management}

\subsubsection{FY98 Accomplishments}

Significant project management activities conducted during FY98 have been discussed in Section 1.0. This section summarizes the activities in bullet form.

- Stakeholder input and regulatory direction was sought in four quarterly meetings with DOE and NMED representatives.

- $\quad$ An EEG was formed to provide extemal opinion on the implementation of the activities described in the Hydrogeologic Workplan and the GWPMPP and to serve as a peer review committee for on-going implementation strategies.

- An External Evaluation Group Action Plan (Nylander, 1999) was written to address implementation of the EEG's recommendations.

\subsubsection{FY99 Planned Activities}

- Hold GIT meetings on a biweekly basis, or as often as necessary to respond to program activities.

- Collect stakeholder input and regulatory direction in four quarterly meetings with DOE and NMED representatives.

- Ensure external program review by the EEG in two meetings and review of documents as necessary.

- Implement EEG recommendations as described in the EEG Action Plan (Nylander, 1999).

- Based on EEG recommendations, make efforts to reach consensus with NMED on two issues in FY99: (1) approach for continued investigations when contamination is detected in a regional aquifer well and (2) establishing the basis for groundwater quality limits. Initial discussions of proposed approaches for both of these issues will be discussed at the Quarterly Meeting (February 3,1999 ) and preliminary drafts of the approaches will be discussed at the Annual Meeting in March, 1999.

\subsection{Information Management}

This section summarizes progress towards developing a Hydrogeologic Workplan database (HWPDB) in support of the well drilling and sampling activities and data needs described in the Hydrogeologic Workplan. The objective is to develop a database that contains both the analytical and physical groundwater data. These data will include historic data and data collected through the MWIP. While the database will be primarily designed to support modeling efforts conducted as part of the Hydrogeologic Workplan, it will be accessible to all groups involved in the Hydrogeologic Workplan and to State regulators and oversight personnel. 


\subsubsection{Progress During FY98}

Activities identified in the FY97 Groundwater Annual Status Summary Report were accomplished to the degree possible. Most activities described are ongoing efforts to develop and maintain the database, and improve database usability.

\section{Budget}

A budget describing the tasks and associated costs for developing the HWPDB was developed. The budget development was a cooperative effort between ESH-18, Earth and Environmental Sciences Division (EES), and the ER Field Support Facility. This budget reflects the "end state vision" for the HWPDB. The total dollars required to develop the database were estimated to be $\$ 1.7$ million. This budget request was submitted to the DOE Los Alamos Area Office in November. No response has been received to date. At present there is very little funding for developing the HWPDB.

\section{User Needs Assessment}

Harding Lawson Associates performed a User Needs Assessment for the HWPDB. Their findings included the following recommendations:

- Form a steering committee to coordinate ESH/ER efforts. (We have formed the steering committee from ESH and ER representatives.)

- Manage the HWPDB as a separate database from the ER Database

- Use the existing Facility for Information Management, Analysis, and Display (FIMAD) Geographic Information System as a foundation for the spatial portion of the HWPDB

- Develop a Data and Records Management Plan

- Identify existing records that should be included in the HWPDB

- Include a plan for sharing information with the public and State personnel

All of the recommendations were adopted. Those requiring action have either been completed and are discussed here or are planned to begin in FY99 assuming appropriate funding has been approved.

\section{HWPDB Project Leader}

Effective November 30, 1998, ESH-18 has hired a Project Leader for the HWPDB. The Project Leader's time will be split equally between ESH-18 database support and development of the HWPDB. It will be the Project Leader's responsibility to coordinate with all the participants in the Hydrogeologic Workplan to develop the HWPDB.

\subsubsection{FY99 Planned Activities}

- Development and formalization of the "end state vision" by the HWPDB Project Leader is planned for FY99.

- Development of a Data and Records Management Plan for the HWPDB by the HWPDB Project Leader is planned for FY99. 
- $\quad$ Consensus will be sought by the HWPDB Project Leader on the priorities for loading the various data sets.

- A data repository will be created and loading or linking of existing data and data currently being collected will begin in FY99.

It should be noted that, at the current levels of funding, the HWPDB will not be a comprehensive database.

\subsection{Modeling}

Groundwater flow and transport modeling has been proposed in the Hydrogeologic Workplan (LANL 1998) as a significant component of Laboratory efforts to better understand the geology, hydrology, and geochemistry of the regional aquifer. Long-term goals of both flow and transport modeling include:

1. Support for the MWIP including siting well locations.

2. Integration of stratigraphic, hydrologic, and geochemical data available for the Pajarito Plateau.

3. Testing of hypotheses concerning predominant flow directions, recharge zones, and potential contaminant migration in the regional aquifer.

\subsubsection{Progress During FY98}

Activities identified in the FY97 Groundwater Annual Status Summary Report were accomplished to the degree possible. Most modeling activities described are ongoing efforts to develop and refine the overall hydrogeologic conceptual model. Table 2.3-1 includes a description of modeling tasks, subtasks, a short synopsis of FY98 status, and future activities. A discussion of FY98 hydrologic, geologic, and geochemical modeling activities and FY99 planned activities follows.

\section{Hydrologic Modeling Activities}

\section{Regional Aquifer Modeling Activities}

A groundwater flow model for the Los Alamos regional aquifer is being developed to complement the MWIP. The broad goals for this modeling work include (1) integration of geologic and hydrologic data, (2) refinement of our conceptual model for flow in the regional aquifer, and (3) simulation of potential contaminant transport. To date, a hydrostratigraphic framework model and a steady-state flow model of the regional aquifer have been developed. The model has been calibrated to water levels measured in 770 domestic, test, and supply wells under non-pumping conditions.

To accomplish modeling goals, a fluid flow and transport code was developed at LANL called FEHM (Zyvoloski et al., 1996). FEHM has a number of capabilities that will be critical to the success of this project, including simulation of multi-phase flow and reactive-transport. Grid-generating software, also developed at LANL (Trease et al., 1996), facilitates development of complex computational grids that can be used to represent subsurface hydrostratigraphy. The authors of the FEHM code have developed the current version of the code under the software QA program for the Yucca Mountain Site Characterization Program. Therefore, a QA pedigree has been established, and the code version is tracked using configuration management software (Dash et al., 1997). 
Table 2.3-1. Status of FY98 Non-Field Activitles

\begin{tabular}{|c|c|c|c|}
\hline Task & Subtasks & 1998 Status & Future Activities \\
\hline \multirow[t]{4}{*}{$\begin{array}{l}\text { Develop } \\
\text { Geologic Model }\end{array}$} & $\begin{array}{l}\text { Complle and publish drilling and completion data from all } \\
\text { significant boreholes. }\end{array}$ & $\begin{array}{l}\text { Completed interim completlon reports for R-9 } \\
\text { and R-12. }\end{array}$ & $\begin{array}{l}\text { Develop complellon reports for alluvlal, perched } \\
\text { intermediale, and regional aquifer wells as they } \\
\text { are installed. }\end{array}$ \\
\hline & $\begin{array}{l}\text { Pertorm comprehensive revlew of three-dimensional (3-D) } \\
\text { stratigraphy including analytical chemlstry and mineralogy } \\
\text { necessary to make stratigraphic correlations between } \\
\text { boreholes, integrale newly-collecled geologic data into } \\
\text { structure-contour maps, isopach maps and cross section }\end{array}$ & $\begin{array}{l}\text { Activities in FY98 were directed at migrating the } \\
\text { site-wide 3-D Geologic Model to Stratamodel. }\end{array}$ & $\begin{array}{l}\text { Data from R-9, R-12, R-25, R-15 and other } \\
\text { boreholes are being incorporated into cross } \\
\text { sectlons and structure contour maps. } \\
\text { Incorporate basalts and Tshicoma lava flow } \\
\text { units into model } \\
\text { Develop a data model for the Chaquehul Fm. }\end{array}$ \\
\hline & $\begin{array}{l}\text { Develop 3-D geological database to include surface } \\
\text { geology, structural geology, and borehole stratlgraphy. }\end{array}$ & $\begin{array}{l}\text { Quality assurance (QA) performance on } \\
\text { migrated model and contact surfaces and } \\
\text { isopachs evaluated to provide an intemally } \\
\text { consistent model of the 3-D stratigraphy }\end{array}$ & $\begin{array}{l}\text { QA of migrated model and incorporation of new } \\
\text { drill hole and surface data into model. } \\
\text { Produce Frijoles Quadrangle from 3-D } \\
\text { database. } \\
\text { Develop geohydrologic atlas and web page. }\end{array}$ \\
\hline & $\begin{array}{l}\text { Salvage of data from stratigraphic and geochemical } \\
\text { analysis of avallable canyon bottom core samples }\end{array}$ & $\begin{array}{l}\text { Because of budgetary constralnts, this activity } \\
\text { was deferred to a later date }\end{array}$ & $\begin{array}{l}\text { ER's Canyons Focus Area will hire a GRA in } \\
\text { FY98 to log these sediments }\end{array}$ \\
\hline $\begin{array}{l}\text { Develop } \\
\text { Hydrologic Model }\end{array}$ & $\begin{array}{l}\text { Compile and publish hydraulic characteristic data: } \\
\text { Bandelier Tuff - Assemble hydrologic laboratory test } \\
\text { results of Bandelier Tuff core from across the Plateau. } \\
\text { Evaluate test results for valldity. Calculate unsaturated } \\
\text { hydraulic propertles from moisture retention } \\
\text { characteristics. Summarize data by stratigraphic unit and } \\
\text { locations. } \\
\text { Determination of vadose zone fluxes in Los Alamos mesas } \\
\text { using chloride and stable isotope proflles. Analyze soll } \\
\text { moisture for chloride mass and isotope ratios. Calculate } \\
\text { fluxes from tracer profiles. } \\
\text { Hydrologic parameler estimalion for the Pajarito Plateau, } \\
\text { Including in-situ hydraulic testing of wells. Load avallable } \\
\text { hydrologic measurements in 3-D database. Statistically } \\
\text { describe zones and regions. }\end{array}$ & $\begin{array}{l}\text { Data on Bandeller Tuff hydraullc characteristlcs } \\
\text { from TA-21 and TA-49 are included in ER RCRA } \\
\text { facility Investigation (RFI) reports for those sites. } \\
\text { A report was written comparing the chlorlde } \\
\text { profile results from DP mesa and TA-16. } \\
\text { Known hydraulic properties of the regional } \\
\text { aquifer were incorporated into the regional-scale } \\
\text { hydrologic model. }\end{array}$ & $\begin{array}{l}\text { Hydraullc properties of Bandelier Tufi will be } \\
\text { evaluated for testing in each characterization } \\
\text { borehole. } \\
\text { Continue to analyze soll molsture for chloride } \\
\text { mass and isotope ratlos at regular intervals in } \\
\text { each characterization borehole. } \\
\text { Use existing and newly collected hydrologic } \\
\text { properties of the regional aquifer in plateau- } \\
\text { scale model. }\end{array}$ \\
\hline
\end{tabular}


Table 2.3-1. Status of FY98 Non-Field Activitles (continued)

\begin{tabular}{|c|c|c|c|}
\hline Task & Subtasks & 1998 Status & Future Actlvilies \\
\hline \multirow[t]{4}{*}{$\begin{array}{l}\text { Develop } \\
\text { Hydrologic Model } \\
\text { (continued) }\end{array}$} & $\begin{array}{l}\text { Evaluate Water Quality Data: } \\
\text { Consolidate historical water quality data in database and } \\
\text { perform trend analysis. } \\
\text { Evaluate water quality varlations and vertical stratification } \\
\text { within the regional aquifer using water samples from } \\
\text { supply wells. Pull permanent pump and isolate discrete } \\
\text { sample zones (46-fl lengths) in each well using hydraulic } \\
\text { packers. Sample with lemporary pump. }\end{array}$ & $\begin{array}{l}\text { Completed report on the trend analysis San } \\
\text { Ildefonso Pueblo. Made water quality data } \\
\text { available vla the internet. } \\
\text { Zonally sampled new supply wells GR-1, GR-2, } \\
\text { GR-3, and GR-4 in Guaje Canyon during } 1998 \\
\text { before these wells entered routine servlce. }\end{array}$ & $\begin{array}{l}\text { Continue trend analysis on the historic data and } \\
\text { focus on evaluating trends by drainage basins. } \\
\text { Zonally sample water supply wells as the } \\
\text { opportunity arises during maintenance. }\end{array}$ \\
\hline & $\begin{array}{l}\text { Inventory springs on-slte and near Laboratory boundarles } \\
\text { by reviewing existing Laboratory and the United States } \\
\text { Geological Survey (USGS) reports for initial Inventory. } \\
\text { Perform addlitional fleld reconnaissance. Supplement with } \\
\text { aerial photography where possible. Select springs with } \\
\text { discrete discharge points. Install fiow and monitoring } \\
\text { probes }\end{array}$ & $\begin{array}{l}\text { Tracer tests were completed tor selected } \\
\text { springs In TA-16. In one test, the tracer traveled } \\
\text { from the pond to Sanitary Wastewater Systems } \\
\text { Consolidation (SWSC) spring in } 3 \text { months and } \\
\text { fracture flow seemed to be controlling tracer. }\end{array}$ & $\begin{array}{l}\text { Continue to obtain fleld observations from } \\
\text { Laboratory and NMED personnel. Continue ER } \\
\text { investigations at critical discharge points } \\
\text { (particularly TA-16 and TA-18) where there is } \\
\text { uncertainty if flow is natural spring-fed or } \\
\text { perennial. Continue monitoring of flow and for } \\
\text { bromide tracer and other chemical constituents. } \\
\text { Analyses of the flow and chemistry time series } \\
\text { will be conducted }\end{array}$ \\
\hline & $\begin{array}{l}\text { Long-term water balance estimates for the Pajarito } \\
\text { Plateau. Install stream gages at upstream and } \\
\text { downstream boundaries of the Laboratory. Continuously } \\
\text { measure evapotranspiration (ET), precipitation, and } \\
\text { groundwater levels. }\end{array}$ & $\begin{array}{l}\text { Data collected in most regional aquifer test } \\
\text { wells, and some intermediate and shallow } \\
\text { alluvial wells. Stream flow measurements } \\
\text { collected from } 19 \text { stations. Precipitation data } \\
\text { collected from } 7 \text { stations and ET data collected } \\
\text { from } 2 \text { stations. }\end{array}$ & $\begin{array}{l}\text { Water level data will be collected annually. } \\
\text { Stream flow gaging stations will be installed at } \\
\text { canyon confluences and Laboratory boundaries }\end{array}$ \\
\hline & Groundwater flow modeling using the FEHM code & $\begin{array}{l}\text { Developed a regional-scale model that } \\
\text { incorporated the geologic framework model, had } \\
\text { a computational grid, used initlal permeablity } \\
\text { estimates that were informed by dala, had } \\
\text { steady-state model callbratlon which resulted in } \\
\text { refined permeability estimates, and evaluated } \\
\text { conceptual model alternalives, including flow } \\
\text { directlons and sources of recharge. }\end{array}$ & $\begin{array}{l}\text { Improve calibration of the regional-scale model, } \\
\text { incorporate geochemical data and publish } \\
\text { conceptual and numerical models. Create a } \\
\text { high-resolution Pajarito Plateau-scale model, } \\
\text { conduct sensitivity analyses to ldentify areas of } \\
\text { critical data needs, use geostatistics to simulate } \\
\text { heterogeneity within hydrostraligraphic units, } \\
\text { and incorporate pumpling effects/transients }\end{array}$ \\
\hline $\begin{array}{l}\text { Develop } \\
\text { Geochemical } \\
\text { Model }\end{array}$ & $\begin{array}{l}\text { Hydrogeochemical and statistical evaluation of solute } \\
\text { distributions on the natural surface and groundwaters }\end{array}$ & $\begin{array}{l}\text { Expanded statistical evaluation of solute } \\
\text { distributtons for LANL background distributions. } \\
\text { Incorporated geochemical data from R-9, R-12, } \\
\text { and } \mathrm{A}-25 \text {. }\end{array}$ & $\begin{array}{l}\text { Continue hydrochemical analyses of } \\
\text { groundwater and surface water to develop } \\
\text { representative distributions that can be used in } \\
\text { hydrologic modeling. }\end{array}$ \\
\hline
\end{tabular}


Table 2.3-1. Status of FY98 Non-Fleld Activities (continued)

\begin{tabular}{|c|c|c|c|}
\hline Task & Subteake & t898 Status & Future Actlvities \\
\hline \multirow[t]{2}{*}{$\begin{array}{l}\text { Develop } \\
\text { Geochemical } \\
\text { Model (continued) }\end{array}$} & $\begin{array}{l}\text { Geochemical characteristics of key subsurface } \\
\text { geohydrologlc units }\end{array}$ & $\begin{array}{l}\text { Characterized hydrochemistries of alluvium, } \\
\text { perched intermediate zones, and regional } \\
\text { equifer and associated aquifer materlal in R-9, } \\
R-12 \text {, and R-25. }\end{array}$ & $\begin{array}{l}\text { Continue to characterize hydrochemistry of } \\
\text { alluvium, perched intermediate zones, and } \\
\text { regional aquiler and associated aquifer material } \\
\text { from boreholes as they are drilled and } \\
\text { completed. }\end{array}$ \\
\hline & Geochemical modeling & $\begin{array}{l}\text { Pertormed speciation, mixing, and mineral } \\
\text { saturation calculations using MINTEQA2 and } \\
\text { PHREEQC for water collected from R-9, R-12, } \\
\text { and R-25. }\end{array}$ & $\begin{array}{l}\text { Continue geochemical modeling to understand } \\
\text { important processes occurring along } \\
\text { groundwater flow paths. }\end{array}$ \\
\hline
\end{tabular}


The extent of the Los Alamos regional aquifer model approximately corresponds to the structural boundaries of the Española basin. By extending the flow model well beyond the boundaries of the Pajarito Plateau, the influence of boundary conditions on model results has been minimized. In building the model, a wide range of geologic and hydrogeologic data for the basin was integrated, with the highest priority on detail and accuracy in the vicinity of the Pajarito Plateau. The objective is to build and improve upon previous flow models for the region (e.g., Heame, 1980; Frenzel, 1995) by increasing the amount of geologic detail incorporated, by using a more finely resolved grid (especially in the vertical direction), and by extending the model boundaries to a more physically-meaningful distance.

At present, the Los Alamos regional aquifer model represents a preliminary steady-state groundwater flow model with physically meaningtul boundary conditions and elevation-dependent recharge rates. The lateral boundaries are located as follows: the western edge is defined by topographic divides in the southeast and northern Jemez mountains and the western margin of the Valles caldera; northem edges are defined by the northemmost extent of the Santa Fe Group; the eastern edge is defined along the drainage divide between the Rio Grande and Rio Pecos; and southern edges are defined along the transition zone between the Española basin and the Santo Domingo basin to the south. Most of the lateral boundaries are specified as "no-flow", since they are located either at presumed groundwater divides or in locations where the Santa Fe Group is very thin or absent. Boundaries where water enters or exits the model are along the upper Rio Chama and Rio Grande valleys, along the western margin of the Valles caldera, and along the Española basin/Santo Domingo basin transition zone. The upper boundary represents the water table, which receives recharge at rates constrained by observed rainfall data and elevation dependent ratios of precipitation-to-recharge.

Calibration results demonstrate the ability of the model to reproduce observed heads in the vicinity of LANL and to predict reasonable fluxes across model boundaries. The relative magnitude of fluxes into the model along northern river valleys, out of the model to the south, and towards the Rio Grande in the center compare favorably to values presented in previously published reports. The sensitivity of the model to assumptions about recharge, hydraulic conductivity, and the significance of the Pajarito fault zone has been investigated. Our preliminary conclusions include the following: (1) a steady-state calibration is insensitive to assumptions about the permeability of both the Pajarito fault zone and the "Chaquehui" Formation, and (2) the model is very sensitive to recharge rates and therefore further calibrations may be useful in constraining the range of plausible recharge rates in this area. For a more detailed description of the Los Alamos regional aquifer model and preliminary results, see Keating et al. (1998).

\section{Other Hydrologic Modeling Activities}

Smaller-scale modeling efforts were performed or began during FY98 and are intended to ultimately feed into the regional model or subsets of it. These efforts focus more on the unsaturated zone than does the regional model.

One modeling activity using data from TA-54 Area $G$ addressed deep drying within the mesas. Previous studies using natural chloride and stable isotope tracers have indicated that deep evaporation can dry out the mesa subsurface which results in small downward flux rates of liquids (Newman, 1996; Newman et al., 1997). Stautfer and Birdsell (work in progress) modeled topographically driven airflow in mesas and found that air flow through a fracture system can explain the existence of low moisture contenthigh chloride zones deep within mesas. These dry zones reduce the downward flux rates of liquids in mesas, but the airflow may increase the movement of volatile species.

Development of a hydrologic model for the lower Los Alamos Canyon was started. Activities thus far have focused on developing a representative hydrostratigraphic model for the canyon. The recent stratigraphic 
and hydrologic results from borehole R-9 have been critical for developing the Los Alamos Canyon hydrostratigraphic framework. The observations of the perched zones and the refined stratigraphy from the R-9 drilling have allowed the development of a more representative conceptual model of the lower part of the canyon, which should translate to better numerical flow models.

Unsaturated flow beneath Mortandad Canyon was modeled by Dander (1998) as part of his master's thesis. This study was conducted to develop an understanding of the unsaturated hydrologic behavior below the canyon floor. The main goal of this study was to evaluate the hypothetical performance of the vadose zone above the water table. Numerical simulations of unsaturated groundwater flow at the site were conducted using the FEHM code. A two-dimensional (2-D) cross section along the canyon's axis was used to model flow between an alluvial groundwater system and the regional aquifer approximately $300 \mathrm{~m}$ below. Using recharge estimated from a water budget developed in 1967, the simulations showed waters from the perched water table reaching the regional aquifer in 13.8 years, much faster than previously thought. Additionally, simulations indicate that saturation is occurring in the Guaje Pumice bed and that the Tshirege Unit $1 B$ is near saturation. Lithologic boundaries between the eight lithologic units represented in the model play an important role in flow and solute transport within the system (though the values of permeability are uncertain for some units). A component of horizontal flow is shown to occur in three thin zones above capillary barriers; however, vertical flow dominates the system. Other simulations were conducted to examine the effects of changing system parameters such as varying recharge inputs, varying the distribution of recharge, and bypassing fast-path fractured basalt of uncertain extent and properties. In general, the travel time to the regional aquifer varies inversely with recharge rate. Thus doubling the recharge rate will halve the travel time. System sensitivity was also explored by changing model parameters with respect to size and types of grids and domains, and the presence of dipping stratigraphy.

\section{Geologic Modeling Activities}

A revised digital geologic model (FY98 model) has been developed for LANL. This model resolves all inconsistencies that previously resulted in the intersection of stratigraphic surfaces. A major effort was also made to identify the extent of additional pre-Bandelier lava flow units that could have major impacts on groundwater flow. Top and bottom surfaces were created for four basalt units as well as two quartz latite flows of the Tshicoma Formation. These new units have not yet been incorporated into the model due to surface intersection problems and pending development of appropriate methods to import these discontinuous surfaces into the Stratamodel software package. As these units have a major impact on models of ground water flow, efforts are continuing on resolving outstanding issues and incorporating these data into the model. An interim FY99 model incorporating these units should be available by early January. The new FY98 model is available at FIMAD.

The geologic model was used to provide quantitative predictions of the depths of stratigraphic contacts for boreholes R-9, R-12, and R-25. Drilling results from borehole R-9 confirmed the importance of the deeper basalts (pre-Bandelier) in any hydrogeologic model. New data to help define these deeper units were collected and include: geologic age and rock chemistry data, the geologic map of the White Rock Quadrangle (Dethier, 1997), and drilling results from the MWIP R-series wells, and the GR-series water supply replacement wells in the Guaje well field.

\section{Geochemical Modeling Activities}

Geochemical modeling was conducted for borehole R-9 using the computer code, MINTEQA2 (Allison et al., 1991) to quantify adsorption of uranium (uranyl) onto hydrous ferric oxide (HFO). The results are 
briefly discussed here while a more detailed description is provided in the summary for Aggregate 1 FY98 Investigations (Section 4.1.1).

Results of the adsorption modeling suggest that, in the lower perched zone, over half of the uranyl present is bound as a surface complex, $\mathrm{SO}_{2} \mathrm{UO}_{2}{ }^{+}$. The remaining dissolved (non-sorbed) uranium occurs mainly as $\mathrm{UO}_{2}\left(\mathrm{CO}_{3}\right)_{3}{ }^{4}$ with some $\mathrm{UO}_{2}\left(\mathrm{CO}_{3}\right)_{2}{ }^{2 .}$. The model predictions for dissolved uranium are in excellent agreement with the measured values. Uranyl complexation with mobile bicarbonate and carbonate ions in the lower perched zone decreases the amount of adsorption by $41.7 \%$, which results in uranium concentrations exceeding the proposed Environmental Protection Agency (EPA) MCL of $20 \mu \mathrm{g} /$.

In addition to borehole R-9 geochemical modeling, the PHREEQC code was used to examine barium solubility and speciation in TA-16 springs and the Cañon de Valle alluvial system. The results are briefly described in the summary for Aggregate 5 (Section 4.5).

\subsubsection{FY99 Planned Activities}

\section{Hydrologic Modeling FY99 Planned Activities}

Continued calibration of the Los Alamos regional aquifer model will be accomplished by simulating transients in the aquifer. Effects of pumping in Los Alamos, Española, and Santa Fe well fields and simulations of historical trends in water levels will be incorporated into the model. A high resolution submodel of the regional model for the Pajarito Plateau will also be developed. This will allow more detailed predictions at the LANL site. Finally, transport capabilities will be added to the model, both reactive and non-reactive, in order to test its ability to predict the observed concentrations of major ions (e.g., $\mathrm{Na}, \mathrm{Ca}$, $\mathrm{Mg}$ ) and stable isotopes (e.g., $\delta^{18} \mathrm{O}, \delta \mathrm{D},{ }^{14} \mathrm{C}$ ) in wells and springs. This analysis is intended to help refine both the conceptual model and the numerical flow model.

Continued development of the lower Los Alamos Canyon hydrologic model is planned. The focus will be to develop flow models to examine the links between the various aquifers in the lower part of the canyon.

\section{Geologic Modeling FY99 Planned Activities}

The 3-D Site-wide Stratigraphic model maintenance and enhancement activities planned for FY99 include:

1. Migrate the current 3-D Geologic model to the Stratamodel software

2. Extend, refine, or create new grids in Stratamodel for specific applications such as detailed studies at material disposal areas (MDAs) or stream channels.

3. Review and compile existing geologic information, or collect new information as required, to insure that regional extent and/or refinement of the model fulfills modeling requirements.

4. Complete incorporation of older basalt and Tshicoma flow units into the model

5. Develop a basic geologic information/data model for the Chaquehui Formation based on characterization of cuttings from new water supply wells and a possible study of equivalent units having surface exposure. 
6. Assist in developing a geohydrologic atlas to include, at a minimum, spatial distribution of units in 2-D and 3-D, geology at the water table, chemical and physical property information or units, sources of data for the model, and a web page describing and illustrating the geology at LANL.

7. Work with the New Mexico Bureau of Mines to produce the Frijoles Geologic Quadrangle from the existing 3-D database.

8. Creation of FY99 3-D stratigraphic model and updating model on a timely basis when required by customers.

\section{Geochemical Modeling FY99 Planned Activities}

Continued geochemical modeling of the Los Alamos, Sandia, and Mortandad Canyons will be accomplished by (1) incorporating speciation, mineral saturation index, and adsorption computations using alluvial, perched intermediate, and regional aquifer groundwaters as data input, (2) performing adsorption experiments as needed for key contaminants, e.g., uranium and strontium, (3) validating geochemical modeling using water chemistry data, results of mineralogical analyses, and hydrologic properties of different aquifer materials, and (4) performing risk analyses using geochemical data.

Geochemical modeling of Cañon de Valle perched zones and regional aquifer groundwater will be initiated by (1) incorporating speciation, mineral saturation index, biodegradation and adsorption computations; (2) performing biodegradation experiments for key HE contaminants as needed, e.g., hexahydro-1,3,5-trinitro-1,3,5-triazine (RDX) and 2,4,6-trinitrotoluene (TNT); (3) validating geochemical modeling using water chemistry data, results of mineralogical analyses, and hydrologic properties of different aquifer materials; and (4) performing risk analyses using geochemical data.

Additional geochemical modeling of barium speciation and solubility will be performed as more water chemistry time-series data is collected at TA-16. A summary of FY98 barium modeling results are included in the discussion of Aggregate 5 (Section 4.5). 


\subsection{FY98 HYDROGEOLOGIC CONCEPTUAL MODEL (AGGREGATE 9)}

Aggregate 9 (site-wide aggregate) addresses the entire Laboratory. It must integrate all available information from field and modeling studies to update the overall hydrogeologic conceptual model for the Laboratory and the Pajarito Plateau. The hydrogeologic conceptual model was described in the Hydrogeologic Workplan. The elements of the hydrogeologic conceptual model are reproduced in this section along with a description of the how the information from site-wide and aggregate-specific activities support refinements to that model. The following sections present the hydrogeologic conceptual model and refinements thereto as they relate to mesas, alluvial groundwater, intermediate perched groundwater, and the regional aquifer.

\subsection{Hydrogeologic Conceptual Model for the Mesas}

There are five elements (A-E) of the hydrogeologic conceptual model that pertain to the mesas. The majority of FY98 efforts further strengthen the hydrogeologic conceptual model mesa elements. There has been some reduction in uncertainty regarding surface recharge on the western margin of the Laboratory.

Element A: Relatively small volumes of water move beneath the mesa tops under natural conditions, due to low rainfall, high evaporation, and efficient water use by vegetation. Atmospheric evaporation may extend within mesas, further inhibiting downward flow.

Analyses of isotope and chloride content in FY97 of core from TA-49 and TA-54 suggest that the portion of the mesa above the neighboring canyon bottom experiences a higher rate of pore water evaporation than does the part of the mesa lying below the canyon bottom. This enhanced evaporation apparently occurs by air movement along fractures and stratigraphic features such as interflow boundaries and surge beds. The agreement of results from two sites that are widely separated suggests that this phenomenon may occur at mesa settings in the lower rainfall portion of the Laboratory. This drying process results in very low infiltration rates within the mesa.

Element B: The amount of mesa top recharge along the western portion of the Laboratory is uncertain. Higher rainfall, increased vegetative cover, and increased welding and jointing of the tuff might lead to different recharge rates than those observed in better studied portions of the Laboratory.

Insights into the subsurface hydrogeologic conceptual model for the near-surface western portion of the Laboratory come from examination of detailed hydrographs for the springs at TA-16 (Aggregate 5, Section 4.5) and the drilling of borehole R-25. In addition, tracer studies at TA-16 indicate relatively direct connections of effluent sources with pathways to these springs. The data suggest that groundwater flow in this area is structurally controlled by surge beds and/or fractured intervals (LANL 1998a; LANL 1998b). Spring discharge and groundwater flow at shallower depths (less than $200 \mathrm{ft}$ ) evidently occurs as a result of highly channelized flow along discrete zones rather than as discharge from a larger porous media volume. Contaminant transport through these systems thus may be rapid and seasonally variable.

Fracture flow probably plays a significant role in water movement through the shallower depths at TA-16. Based on borehole camera photography at $R-25$, it is possible that fracture flow contributes recharge to the deeper groundwater system. 
Uncertainty in this element remains high. The investigations to date confirm that the recharge rates are probably quite different than have been observed in other portions of the Laboratory, but quantification of those rates will require additional work. Planned FY99 activities in Aggregate 5 will emphasize reducing the uncertainties in the flow paths from the surface to springs and deeper groundwater.

Element C: Mesa top recharge can be locally significant under disturbed surface conditions. Such change occurs when the soil is compacted, when the vegetation is disturbed or when more water is added to the hydrologic system by features such as blacktop, lagoons, or effluent disposal.

Work at TA-16 shows that adding water to a mesa top and a canyon bottom (such as from the 260 outtall) does contribute to recharge to the regional aquifer system (as discovered in borehole R-25). However, the existence and amount of such recharge in the absence of Laboratory discharges is unknown.

There is little uncertainty that disturbed surface conditions alter the recharge on the mesa tops. The magnitude of recharge rate alteration associated with various types of disturbance and the extent of the alteration remain to be further quantified.

\section{Element D: Fractures within mesas do not enhance the movement of dissolved contaminants unless} saturation develops.

Aside from analysis of flow regimes at the TA-16 springs discussed in Element $B$, none of the work in FY98 addressed fracture flow in mesas.

Element E: Contaminants in vapor form readily migrate through mesas. Vapors denser than air will sink.

There are no refinements to this element this year. Work continues on contaminant monitoring and collection of air pressure data within the vapor plumes at MDAs L and G (Aggregate 2, Section 4.2).

\subsection{Hydrogeologic Conceptual Model for Alluvial Groundwater}

There are five elements $(F-J)$ related to alluvial groundwater in the hydrogeologic conceptual model. Work completed in FY98 tends to confirm these elements.

Element F: In drier canyon bottoms, groundwater may occur seasonally in alluvium, depending on the volume of surface flow from snowmelt. storm runoff, and Laboratory NPDES-permitted effluents. As groundwater in the alluvium moves down the canyon, it is depleted by evapotranspiration and infiltration into the underlying rocks.

This element continues to be confirmed by water level measurements in existing alluvial wells and in newly installed wells. Investigations in alluvium in Aggregates 1 and 4 illustrate the transient nature of alluvial groundwater in ephemeral canyons. In Aggregate 1 (Section 4.1), four wells were installed in middle Pueblo Canyon at locations where alluvial groundwater was possibly present. Two of the wells went dry during development. Water levels in all of these wells will be monitored to learn more about seasonal fluctuations, but these initial indications are that sustained alluvial groundwater is not present in that portion of Pueblo Canyon. A similar observation can be made in Aggregate 4 (Section 4.4), where 
two rounds of water level measurements in five Ancho Canyon wells found predominantly dry conditions. This demonstrates the general absence of alluvial groundwater in the north branch of Ancho Canyon but for a few days or weeks a year. The Surveillance Program also confirmed dry conditions in Water Canyon and in the lower segments of Fence and Sandia Canyons through quarterly water level measurements.

\section{Element G: In wetter canyon bottoms, infiltration of NPDES-permitted effluents and natural runoff reaching the stream channel may maintain shallow groundwater in the alluvium. Groundwater levels are typically highest in the late spring due to snowmelt runoff and in mid-to-late summer due to seasonal thunderstorms. Groundwater levels decline during the winter and early summer when runoff is at a minimum.}

This element continues to be confirmed by ongoing field measurements of near-surface hydrologic cycle components and of groundwater. Scoping calculations estimate that the volume of stored alluvial groundwater in the largest canyon systems at the Laboratory is approximately equivalent to the annual volume of streamflow loss (Figure 3.2-1). This suggests that there may be approximately a complete replacement of stored alluvial groundwater by effluents and/or natural runoff every few years. This may vary between canyon systems.

The canyons with the largest natural or anthropogenic surface water flows are those that consistently have alluvial groundwater. Those canyons with the most significant known shallow perched alluvial water bodies are: lower Pueblo, Los Alamos, Mortandad, Pajarito, and Cañon de Valle. Portions of other canyons, such as in Sandia Canyon below the sewage effluent discharge, may also contain more localized sections with alluvial groundwater, but well coverage is incomplete to confirm this. Planned additional shallow wells will assist in completing the mapping of shallow saturation.

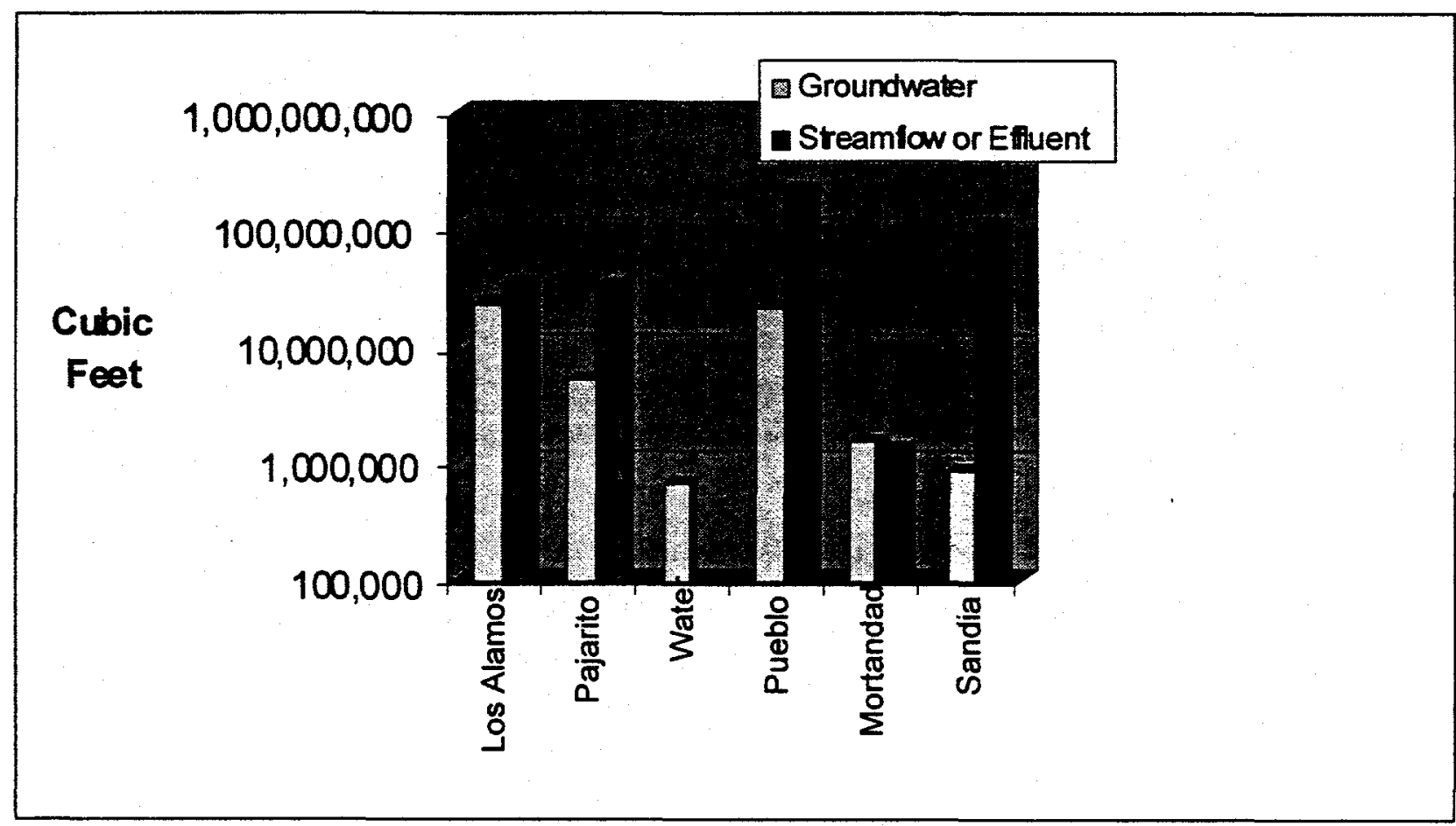

Figure 3.2-1. Volume of shallow groundwater vs. annual streamflow loss and effluent discharge. 
Figure 3.2-1 displays scoping estimates of the approximate volumes of shallow groundwater found in the major "wet" canyons within the Laboratory boundaries. The groundwater in Los Alamos, Pajarito, and Water Canyons was assumed to be principally supported by natural streamflow, and that in Pueblo, Mortandad, and Sandia Canyons was assumed to be supported by effluent discharges. Natural streamflow losses across the Laboratory were calculated from ESH-18 stream gaging data by comparing upstream and downstream flows. Effluent discharges were taken from ESH-18 records. All effluent was assumed to be lost to seepage onsite. The lengths of the "suspected" saturated zones were taken from NMED's "Hydrogeologic Evaluation of Los Alamos National Laboratory" (1996). The following widths and depths of saturation ( $f$ ) were assumed: Los Alamos $(100,15)$, Pajarito/Three Mile $(50,10)$, Water $(20,10)$, Pueblo $(200,35)$, Mortandad $(40,10)$, Sandia $(40,10)$. A porosity of 0.35 was assumed for all canyons.

\section{Element $\mathrm{H}$ : Alluvial groundwater is a source of recharge to underlying intermediate perched zones. usually by unsaturated flow. In wetter canyon bottoms. alluvial groundwater mav also contribute recharge to the regional aquifer.}

Tritium, nitrogen isotope, and anion data from perched zones at boreholes R-9 and R-12 provide confirmation of the viewpoint that there is percolation of Laboratory effluents to significant depths (more than a few hundred feet) in the vadose zone beneath alluvial groundwater in effluent-supplied or "wetter" canyons (Aggregate 1, Section 4.1). Elevated concentrations of uranium, possibly anthropogenic oxalate, and nitrate in some of the perched zones raise questions about the source areas (Aggregate 1). Nitrogen isotope studies (Aggregate 1) suggest that the source of nitrate in perched water from borehole R-12 is most likely sewage effluents. The closest known sewage effluent streams are located approximately three quarters of a mile away in Pueblo Canyon and two miles away in Sandia Canyon.

Alluvial groundwater does contribute a relatively small amount of recharge to the regional aquifer. Tritium activities in regional aquifer samples from boreholes R-9 and R-12 indicate some recharge of water from the land surface to the regional aquifer in a period of 40 years or less (Aggregate 1), but the activities are very low in relation to drinking water standards. These findings support earlier test results obtained in old monitoring wells scattered across the Laboratory. Modeling work completed in Mortandad Canyon (Section 2.3.1) suggests that alluvial groundwater could reach the regional aquifer in approximately ten to one hundred years, depending upon the assumed recharge rate used in the simulations.

Continued work will focus on identitying major flow paths.

\section{Element 1: Dry canyon bottoms contribute little recharge under natural conditions. Long-term addition of effluent to naturally dry canyon bottoms may result in recharge to intermediate perched zones.}

No investigations concerning recharge were conducted in dry canyons in FY98, with the exception of alluvial wells in Ancho Canyon (Aggregate 4, Section 4.4). However, Sandia and Mortandad Canyons are excellent examples of naturally dry canyons that have had the long-term addition of effluent. Previous work in Mortandad Canyon has demonstrated the presence of a subsurface tritium plume and a numerical modeling study in FY98 suggests that flow is primarily downward and may reach the regional aquifer in 10 to 100 years (depending on recharge rates used) (Section 2.3.1). 
There is relative certainty in this aspect of the model, which drove the Hydrogeologic Workplan to prioritize wells in "wet" canyons. The installation of borehole R-31 in Ancho Canyon will be a test of this model element.

Element J: In a few cases where saturated flow might occur, faults, fractures, joints, surge beds, and permeable geologic units (e.g. Guaje Pumice. Cerro Toledo, and Puye Formation) that underlie alluvial saturated sediments or intermediate perched zones could provide pathways for downward water movement.

At TA-16 near the western boundary of the Laboratory (Aggregate 5, Section 4.5), the flow of water from the surface to units within the upper 200 feet of the vadose zone seems to be influenced by structural features (fractures, faults, and joints) and surge beds. However, with respect to deeper geologic units, the FY98 work does not provide a significantly enhanced understanding of their role in subsurface flow. The presence of Laboratory contaminants in borehole R-25 at relatively short lateral displacement from the likely sources indicate plateau recharge over relatively short lengths of stream channel, or possibly even more direct pathways such as via fractures. Dual porosity (fracture flow and matrix flow) probably accounts for movement of groundwater through the more welded sections of this zone. Matrix flow probably dominates through the many less welded sequences at TA-16.

\subsection{Hydrogeologic Conceptual Model for Intermediate Perched Groundwater}

Five elements $(K-O)$ comprise the hydrogeologic conceptual model for intermediate perched groundwater. The work completed in FY98 tends to support all of the elements, although understanding of the intermediate zones is still very limited.

\section{Element K: Intermediate perched zones occur beneath major canyon systems, particularly those that head in the Jemez Mountains. Intermediate perched zones may receive recharge from watersheds west of the Laboratory.}

This element is supported by work done in FY98 and previously. Intermediate perched zones have been identified in Pueblo Canyon, Los Alamos Canyon (R-9 and other wells) and Sandia Canyon (R-12) (Aggregate 1, Section 4.1).

The greatest uncertainty associated with this element is whether other canyons have intermediate perched groundwater zones and how the zones are distributed. One of the objectives of the deep boreholes drilled for this project is to locate possible perched zones.

Element L: In addition to the availability of recharge from overlying alluvial groundwater, the location of intermediate perched zones is controlled by hydrogeologic characteristics of subsurface units, mainly lithology and permeability. In some cases, such as with interlayered basalts and conglomerates, intermediate perched zones could occur at several depths beneath a canvon.

The intermediate depth perched groundwater zones present beneath Los Alamos Canyon are more numerous than previously recognized. Borehole $R-9$ encountered five perched systems within the vadose zone. The saturated thicknesses of these zones were variable: some of the zones were thin (a few feet thick) while others showed saturated thicknesses greater than anticipated (more than 70 feet). 
Additionally, the field observations indicate some of the perched horizons are confined. The data suggest that delineating the direction or velocity of groundwater flow for all but the largest saturated zones may prove difficult.

The uncertainty associated with this element is very large. This uncertainty led to the Hydrogeologic Workplan approach of drilling to the regional aquifer to discover all of the perched zones and perching layers.

Element M: The intermediate perched zones have not been observed to extend laterally beneath mesas. However. some lateral spreading of perched groundwater may occur down gradient, if the canven course and the dip of the perched zone de not coincide.

This element of the model must be changed based on work completed in FY98 and earty FY99, because it appears that this is not the case everywhere on the plateau: The chemistry of intermediate perched zones encountered in boreholes R-9 and R-12 (Aggregate 1, Section 4.1) suggest that the zones are not connected beneath the mesa. However, a vertically extensive perched intermediate groundwater zone was encountered in borehole R-25 beneath the mesa at TA-16 (Aggregate 5, Section 4.5). The perched zone at R-25 is probably the same as that encountered in SHB-3, making the lateral extent of this zone beneath a mesa setting greater than $2 \mathrm{~km}$. This result is consistent with hydrogeologic model element $B$, regarding the likelihood that recharge is different along the western side of the Laboratory.

Large uncertainty is associated with this model element. It is apparent that intermediate perched zones can occur under mesas in certain areas. Continued work must address identifying the characteristics that lead to intermediate perched water beneath certain mesas.

Element $\mathrm{N}$ : Some hydrologic evidence suggests the existence of an intermediate perched zone within the Bandelier Tuff along the westem portion of the Laboratory, but this can not be confirmed without further study.

Work completed in FY98 at TA-16 supports previous conclusions that there are shallow, thin perennial ribbons of saturated flow within the upper part of the Tshirege Member of the Bandelier Tuff, but there is not a singly lateral extensive perched zone (Aggregate 5, Section 4.5). These ribbons feed three springs that issue from the mesa (Martin, SWSC, and Buming Ground). In addition, transient saturated zones may also supply water to the springs and transport contaminants. These saturated zones may not be as large or persistent as that supplying the Water Canyon Gallery to the west.

Drilling of R-25 has confirmed the occurrence of a large intermediate perched zone at a depth of about $750 \mathrm{ft}$ below the mesa surface. The upper part of this zone lies in the lower part of the Otowi Member of the Bandelier Tuff; the lower part in the Puye Formation. The upper portion of this zone was previously encountered in well SHB-3, to the southwest.

There is moderate uncertainty associated with this element. Much of the ER project work at TA-16 is focused on quantitying flow and transport through the shallow saturated ribbons and in transient saturated zones. 
Element 0: Contaminant concentrations in water entering these intermediate perched zones are diluted. Lateral down-canyon flow within intermediate perched zones could contribute to significant transport of contaminants away from their surface source.

Observations at boreholes R-9 and R-12 support this element of the hydrogeologic conceptual model. Nitrogen isotope studies (Aggregate 1, Section 4.1) suggest water in the intermediate perched groundwater has been transported laterally a significant distance, both through surface water and possibly the intermediate perched zone. The isotopes indicate that the nitrate in perched water from borehole R-12 is from sewage effluents. The closest known sewage effluent streams are located approximately three quarters of a mile away in Pueblo Canyon and two miles away in Sandia Canyon. Tritium and uranium present in the perched zones in boreholes R-9 and R-12, and oxalate present in R-9, provide confirmation of transport of contaminants in intermediate perched zones.

Uncertainty is associated with this element regarding flowpaths. One objective of future work is to further refine the understanding of these flow paths.

\subsection{Hydrogeologic Conceptual Model for the Regional Aquifer}

Five elements comprise the hydrogeologic conceptual model for the regional aquifer. The FY98 work provides further knowledge of the regional aquifer from 3 wells and the regional scale modeling. The five regional aquifer elements are discussed below.

Element P: The slope of the top of the regional aquifer suggests that the flow of groundwater is generally toward the east or southeast, toward the Rio Grande.

Uncertainty associated with this element lies in the scale at which perturbations in the regional aquifer gradient become important. It is clear that on a regional scale, the gradient is east to southeast. It is anticipated that on a finer scale the direction of flow may vary due to factors such as paleogeographic features or pumping.

This element will be modified to include the statement "Water supply pumping affects flow directions in the aquifer near the supply wells. The variation of these effects with depth and distance is not known at present. This influence on flow directions could have an important impact on contaminant movement in the regional aquifer".

Element Q: Intermediate perched zone and alluvial groundwater may be minor sources of recharge to the regional aquifer relative to the amount of public water supply pumping from the regional aquifer. The hydraulic connection between the regional aquifer and the land surface is not strong at most locations.

This element of the hydrogeologic conceptual model will be refined. Preliminary analysis of ESH-18 stream gaging data collected since 1994 indicates the volume of natural streamflow losses across the Laboratory may be locally significant, but relatively small overall. The annual volume of regional aquifer recharge from stream bottom infiltration of natural streamflow is calculated to be less than 10 percent of that typically pumped from the Pajarito Well Field for municipal public water supply. However, when the potential for infiltration of effluent discharges is also considered, the potential total volume of annual streamflow losses across the Laboratory may approach one-half of that pumped from the Pajarito Well Field. 
Chemistry data show some component of recent recharge in the regional aquifer, but the magnitude of the hydraulic connection remains to be quantified. The tritium activities in boreholes R-9 and R-12 suggest that surface water has reached the regional aquifer in less than 50 years (Aggregate 1, Section 4.1), corroborating earlier findings from older test wells. Despite the existence of some recharge pathway, however, overall contaminant levels at the eastern boundary of the Laboratory are generally small. The discovery of high explosives in borehole R-25, however, has demonstrated recharge from surface sources to the regional aquifer in relatively short time periods.

Element R: Regional aquifer groundwater within the eastem oortion of the Pajarite Plateau (oenerally along the Rio Grande) is of different recharge origin that under the central part of the Plateau.

This element of the hydrogeologic conceptual model can not be refined based on the work completed in FY98. No data were collected from the eastern portion of the Pajarito Plateau. The drilling and sampling of borehole R-31 in FY99 may provide insight into the question of recharge sources.

Element S: Sources of recharge to the regional aquifer are uncertain. Geochemical data show that the Valles caldera is not the source of major recharge, contrary to statements in earlier Laboratory reports. Major recharge may occur by southerly flow along the late Miocene trough of Purtymun (1984), infiltration along the flanks of the Jemez Mountains, or possibly via percolation beneath canyon bottoms.

The work completed in FY98 may change this element of the model. Recharge sources to the regional aquifer remain uncertain. However, new work supports a possible change in relative importance of some of the sources of recharge. The strong downward vertical gradient encountered in borehole R-25 indicates that the area along the flank of the Jemez Mountains is an area of recharge, with the recharge originating from the Jemez Mountains. Further, as discussed in Element $Q$, the alluvial and intermediate perched groundwater zones are also sources of recharge. For both of these sources, the relative amount of recharge is unknown.

In addition, preliminary modeling of the regional aquifer indicates that a relatively large amount of recharge from the Jemez Mountains might be required to account for regional aquifer elevations in the western portion of the Laboratory. These preliminary modeling results, however, do not support the hypotheses of southerly flow along the Late Miocene trough. These conclusions have important ramifications. Once more conclusive modeling results are obtained, Element $S$ will be modified to reflect them.

Significant uncertainties remain with regard to sources of recharge. Continued characterization of the entire area in conjunction with modeling are necessary to identify and quantify the sources of recharge to the regional aquifer.

Element T: If present, Laboratory-derived contaminants in the regional aquifer are likely to vary in concentration. The contaminant concentrations are probably below maximum contaminant levels (MCLs) for drinking water because (1) regional aquifer underflow dilutes contaminant concentrations in recharge: and (2) contaminant concentrations in alluvial and intermediate perched zone groundwater are expected to decrease with depth due to dilution and geochemical attenuation along vertical migration pathways. 
This element of the hydrogeologic conceptual model is largely supported by the work completed in FY98, but language will be added to reflect the possible role vertical hydraulic gradients may have on contaminant concentrations in the regional aquifer. Although contaminants were detected in boreholes R-9, R-12, (Aggregate 1, Section 3.2.1) and R-25 (Aggregate 5, Section 3.2.5), their concentrations are below MCLs. Vertical gradients in the upper portion of the regional aquifer may also play a role in determining concentrations of contaminants reaching the aquifer. Upward vertical gradients in the regional aquifer are suggested at borehole R-12, based on initial comparison of static water levels in R-12 with the deeper adjacent municipal well PM-1. If upward vertical gradients are present, the potential for Laboratory contaminants reaching the top of the regional aquifer to migrate deeper is reduced. Upward hydraulic gradients are known to exist in wells east of R-12, near the Rio Grande (the old Los Alamos well field). On the other hand, downward vertical gradients are indicated by water levels observed while drilling borehole R-25. In recharge zones it is likely that any contaminants would be carried further down into the regional aquifer, although the dilution would expected to be important in areas of recharge.

A new element shall be added to the hydrogeologic conceptual model pertaining to the regional aquifer. This element addresses the vertical and lateral heterogeneity of the aquifer. The new element, Element $U$, is given as follows:

The hydraulic properties of the regional aquifer are heterogeneous both vertically and laterally. Vertically, hydraulic properties vary greatly between geologic units thereby contributing to varving water yield. Laterally, the regional aquifer commonly exhibits confined characteristics near the Rio Grande but appears to be unconfined in other parts of the Pajarito Plateau. Water level declines due to pumping vary across the Plateau, usually ranging from 0.5 to 3 feet per year. Water levels have declined the least in wells that penetrate a thick zone of permeable sediments that transects the central part of the Plateau.

\subsection{FY98 Revisions to the Hydrogeologic Conceptual Model (Aggregate 9 Conceptual Model Refinements)}

The following text provides a summary of the current understanding of the hydrogeologic environment at LANL as modified from the original conceptual model elements provided in the Hydrogeologic Workplan dated May 22, 1998 (LANL, 1998). Modified elements are in bold font. Added text is underlined while deleted text is lined through.

Element A: Relatively small volumes of water move beneath the mesa tops under natural conditions, due to low rainfall, high evaporation, and efficient water use by vegetation. Atmospheric evaporation may extend within mesas, further inhibiting downward flow.

Element B: The amount of mesa top recharge along the western portion of the Laboratory is uncertain. Higher rainfall, increased vegetative cover, and increased welding and jointing of the tuff might lead to different recharge rates than those observed in better studied portions of the Laboratory.

Element C: Mesa top recharge can be locally significant under disturbed surface conditions. Such change occurs when the soil is compacted, when the vegetation is disturbed, or when more water is added to the hydrologic system by features such as blacktop, lagoons, or effluent disposal. 
Element D: Fractures within mesas do not enhance the movement of dissolved contaminants uniess saturation develops.

Element $E$ : Contaminants in vapor form readily migrate through mesas. Vapors denser than air will sink.

Element $F$ : In drier canyon bottoms, groundwater may occur seasonally in alluvium, depending on the volume of surface flow from snowmelt, storm runoff, and Laboratory NPDES-permitted effluents. As groundwater in the alluvium moves down the canyon, it is depleted by evapotranspiration and infiltration into the underlying rocks.

Element G: In wetter canyon bottoms, infiltration of NPDES-permitted effluents and natural runoff reaching the stream channel may maintain shallow groundwater in the alluvium. Groundwater levels are typically highest in the late spring due to snowmelt runoff and in mid-to-late summer due to seasonal thunderstorms. Groundwater levels decline during the winter and early summer when runoff is at a minimum.

Element H: Alluvial groundwater is a source of recharge to underlying intermediate perched zones, usually by unsaturated flow. In specific wetter canyon bottoms, alluvial groundwater may be a significant source of recharge to the intermediate perched zones and has contributed groundwater to the regional aquifer.

Element I: Dry canyon bottoms contribute little recharge under natural conditions. Long-term addition of effluent to naturally dry canyon bottoms may result in recharge to intermediate perched zones.

Element J: In a few cases where saturated flow might occur, faults, fractures, joints, surge beds, and permeable geologic units (e.g. Guaje Pumice, Cerro Toledo, and Puye Formation) that underlie alluvial saturated sediments or intermediate perched zones could provide pathways for downward water movement.

Element K: Intermediate perched zones occur beneath major canyon systems, particularly those that head in the Jemez Mountains. Intermediate perched zones may receive recharge from watersheds west of the Laboratory.

Element L: In addition to the availability of recharge from overlying alluvial groundwater, the location of intermediate perched zones is controlled by hydrogeologic characteristics of subsurface units, mainly lithology and permeability. In some cases, such as with interlayered basalts and conglomerates, intermediate perched zones could occur at several depths beneath a canyon.

Element $M$ : The intermediate perched zones have not been observed to extend laterally beneath the mesas in the eastern portion of the Laboratory. However, some lateral spreading of perched groundwater may occur down gradient, if the canyon course and the dip of the perched zone do not coincide. Perched intermediate groundwater zones occur beneath the mesas on the western edge of the Laboratory.

Element N: Somo hydrologic ovidence-suggeste the oxistence-of an intemediateporchedzone within the Bandelier Tuff along tho western portion of tho Laboratory, but this can not beconfirmed without further-study. Along the western boundary of the Laboratory, perched groundwater occurs in at least two distinct modes: limited ribbons of shallow 
saturation that are sources of springs in the Tshirege Member of the Bandelier Tutf found to depths of approximately $200 \mathrm{ft}$ below the mesa top, and a separate large perched zone approximately $700 \mathrm{ft}$ below the mesa top occurring in the Otowi Member of the Bandelier Tuff and extending downward into the Puve Formation. The principal recharge source for these zones is probably the Jemez Mountains.

Element O: Contaminant concentrations in water entering these intermediate perched zones are diluted. Lateral down-canyon flow within intermediate perched zones could contribute to significant transport of contaminants away from their surface source.

Element P: The slope of the top of the regional aquifer suggests that the flow of groundwater is generally toward the east or southeast, toward the Rio Grande. Water supply pumping affects flow directions in the aquifer near supply wells. The variation of these effects with depth and distance is not known at present. This influence on flow directions could have an important impact on contaminant movement in the regional aquifer.

Element Q: Intermediate-perched zono-and-alluvial-groundwater may be minor sources-of recharge to the regional aquiler rolative to the amount of public water supply pumping from the regionat aquifer. The hydraulic-connection betweon the regional aquifer-and the land suffaco is not strong at most locations. Along the western edge of the Laboratory deep perched groundwater may be a major source of recharge to the regional aquifer. The volume of on-site regional aquifer recharge from stream bottom infiltration of natural streamflow into alluvial groundwater is small relative to the amount of public water supply pumping from the regional aquifer. When considered also with potential infiltration of effluent discharge steams, however, the annual volume of on-site regional recharge from stream bottom infiltration may be significant.

Element R: Regional aquifer groundwater within the eastern portion of the Pajarito Plateau (generally along the Rio Grande) is of different recharge origin that under the central part of the Plateau.

Element S: Sources of recharge to the regional aquifer are uncertain. Geochemical data show that the Valles caldera is not the source of major recharge, contrary to statements in earlier Laboratory reports. A strong downward vertical hydraulic gradient observed on the western edge of the Laboratory indicates that the area along the flank of the Jemez Mountains is a recharge area with the recharge originating in the Jemez Mountains. Additionally, major recharge may occur by southerly flow along the late Miocene trough of Purtymun (1984), inflitration along the flanks-of the domez-Mountains, or possibly via percolation beneath canyon bottoms.

Element $\mathrm{T}$ : If present, Laboratory-derived contaminants in the regional aquifer are likely to vary in concentration. The contaminant concentrations are probably below maximum contaminant levels (MCLs) for drinking water because (1) regional aquifer underflow dilutes contaminant concentrations in recharge; and (2) contaminant concentrations in alluvial and intermediate perched zone groundwater are expected to decrease with depth due to dilution and geochemical attenuation along vertical migration pathways. Vertical gradients in the upper portion of the regional aquifer affect dilution of contaminant concentrations in the recharge sources, i.e.e upward gradients influence mixing of the recharging water with resident aquifer water while downward gradients inhibit this mixing. 
(New) Element U: The hydraulic properties of the regional aquiler are heterogeneous both vertically and laterally. Vertically, hydraulic properties vary greatly between geologic units thereby contributing to varying water vield. Laterally, the regional aquifer commoniy exhibits confined characteristics near the Rio Grande but appears to be unconfined in other parts of the Pajarlto Plateau. Water level declines due to pumping vary across the Plateau, usually ranging from 0.5 to 3 feet per year. Water levels have declined the least in wells that penetrate a thick zone of permeable sediments that transects the central part of the Plateau.

\subsection{Aggregate 9 FY99 Planned Activities}

Monitoring and data collection activities for near-surface hydrologic cycle components and groundwater levels at various depths similar to those conducted in FY98 are planned. Wells located in normally dry canyon bottoms will be monitored and sampled if groundwater is present.

Twenty-two surface water-gaging stations are to be installed in FY99 to provide additional stream flow measurements at canyon confluences and the Laboratory's east and west boundaries. Decisions on the number of stations, design, locations, and sampling plans were made jointly between ER Project personnel and ESH-18 personnel to meet program needs and regulatory requirements. Data from these stations will provide needed information for a plateau-wide water balance study as well as information on contaminant migration in sediments and surface water. This planned activity will be funded through the Watershed Management Program.

A water balance study in Los Alamos Canyon is planned in FY99. Activities are designed to build upon work previously performed by Robert Gray for a master's thesis (Gray, 1997) The scope of the previously completed work included the computation of a water balance for the Los Alamos Canyon watershed using available meteorological and hydrologic data. The water balance results were then used to constrain the recharge and ET parameters for a 3-D finite-difference groundwater flow model of the alluvial aquifer in Los Alamos Canyon constructed with the USGS's MODFLOW code (MCDonald and Harbaugh, 1988). A steady-state simulation was calibrated to alluvial head data and transient simulations were conducted to test the model's performance. The results of the modeling were used to quantify infiltration seepage from the alluvial aquifer into the canyon's subsurface strata, a significant source of groundwater recharge to the deeper subsurface that is important because of the implications for the mobilization and migration of LANL-derived contaminants along the groundwater flow paths.

The previous work represents an initial effort restricted in scope because of the limited availability of pertinent hydrologic data (i.e., varying streamflow rates and alluvial hydraulic conductivities) and inherent simplifications imposed on the initial hydrologic conceptual model (i.e., aerial recharge was assumed as the dominant recharge mechanism; homogeneous and isotropic conditions were assumed within the aquifer). The subsequent efforts planned for FY99 are designed to (1) provide additional hydrologic data characterizing the hydraulic properties of the alluvium and the nature of stream-aquifer interaction, and (2) refine the groundwater flow model of the alluvial system. The specific activities planned to address these objectives are:

- $\quad$ perform slug tests on additional ER Project alluvial wells and analyze previously collected (FY98) slug test data to determine varying hydraulic conductivities of the alluvium

- $\quad$ collect measurements of the water levels in ER Project alluvial wells on a monthly basis providing data for model calibration 
- $\quad$ refine the groundwater flow model by applying updated hydraulic conductivity data and incorporating focused recharge from the streambed based on limited seepage run data previously collected (in 1995) by the USGS

- $\quad$ perform multiple detailed seepage run analyses by collecting closely spaced measurements of streamflow rates during peak runoff conditions (i.e., spring snowmelt) and additional discrete runoff events including storm events and during low-flow conditions

The results of these efforts will be to improve the current alluvial aquifer flow model and quantify the amount of groundwater recharge due to infiltration seepage from the alluvial system in Los Alamos Canyon with a higher degree of confidence than was previously determined. This information will then be available for application to additional groundwater modeling efforts planned by EES-5 to simulate flow conditions in the deeper subsurface. The planned FY99 efforts involve a limited scope of activities designed to permit specific modifications to the pre-existing flow model, thereby enhancing the veracity of its results. Previous streamflow data will be utilized to quantify focused recharge to the alluvium from the streambed, while the previous water budget results will continue to be used to constrain the aerial recharge and ET rates applied to the rest of the model. The detailed streamflow data, alluvial head data, and slug test data to be collected will be useful for future efforts projected to carry over into FYOO and directed towards updating and refining the water balance for the Los Alamos Canyon watershed and further refining the flow model of the alluvial system. 


\subsection{AGGREGATE-SPECIFIC FIELD ACTIVITIES}

The FY98 investigations that occurred within Aggregates $1-8$ are described in the following sections. Figures 4-1 and 4-2 show the locations of aggregates with respect to regional wells and alluvial wells (these locations are placeholders where alluvial wells might be installed, but actual locations will be determined as ER canyons investigations evaluate characterization requirements in each canyon system). Figure 4-3 shows the transect locations of the geologic cross sections. Based on the data collected in the investigations, refinements to the conceptual models are presented. A brief description of proposed FY99 activities is also included.

\subsection{Aggregate 1}

Aggregate 1 is bounded on the north by Pueblo Canyon, on the south by Sandia Canyon, on the east by state road NM 4, and to the west by the Jemez Mountains (Figure 4.1-1). Aggregate 1 includes the Los Alamos townsite, and currently active technical areas: TA-21, which is on DP Mesa; TA-43, which is the site of the Los Alamos Medical Center; TA-53, which is the site of the Los Alamos Neutron Science Center; and TA-73, which is the Los Alamos Airport. This aggregate also includes two inactive technical areas (TA-0 and TA-45) where early Laboratory operations took place.

\subsubsection{Aggregate 1 FY98 Investigations}

\section{Borehole R-9}

Borehole R-9 drilling results were mostly summarized in last year's annual report and a draft completion report has been prepared (Broxton et al., 1998). R-9 is currently completed as a temporary well at a depth of $710 \mathrm{ft}$ as shown in Figure 4.1-2. The decision to complete R-9 as a temporary well was made to allow time for further data collection of water levels in the regional aquifer, particularly with respect to pumping from nearby water supply wells. Also, the position of the top of the regional aquifer in R-9 was uncertain because of the occurrence of multiple saturated zones ranging in depth from $579 \mathrm{ft}$ to $688 \mathrm{ft}$. The delay in completing R-9 as a well allowed borehole R-12 to be drilled before the R-9 well design was finalized. Borehole R-12 drilling confirmed that the top of the regional aquifer occurs at a depth of $688 \mathrm{ft}$ at R-9. Completion plans for R-9 are described in Section 4.1.3.

A pressure transducer was installed at the top of the regional aquifer shortly after the temporary well was completed and the change in static water level was recorded for a one-year period. Water level and atmospheric pressure were recorded on a 15-minute interval. Figure 4.1-3 shows the relationship between atmospheric pressure and the static water level in the regional aquifer. A rise in atmospheric pressure results in a lowering of the static water level. Conversely, the static water level rises during periods when the atmospheric pressure decreases. As shown on Figure 4.1-3, the change in atmospheric pressure over a period of a few days in February, 1999 resulted in a $1 \mathrm{ft}$ change in the static water level. The one-year record collected in borehole R-9 indicates an annual change of less than $0.1 \mathrm{ft}$ for the static water level at the top of the regional aquifer. Water levels in the regional aquifer did not appear to respond to pumping cycles from nearby water supply wells. 


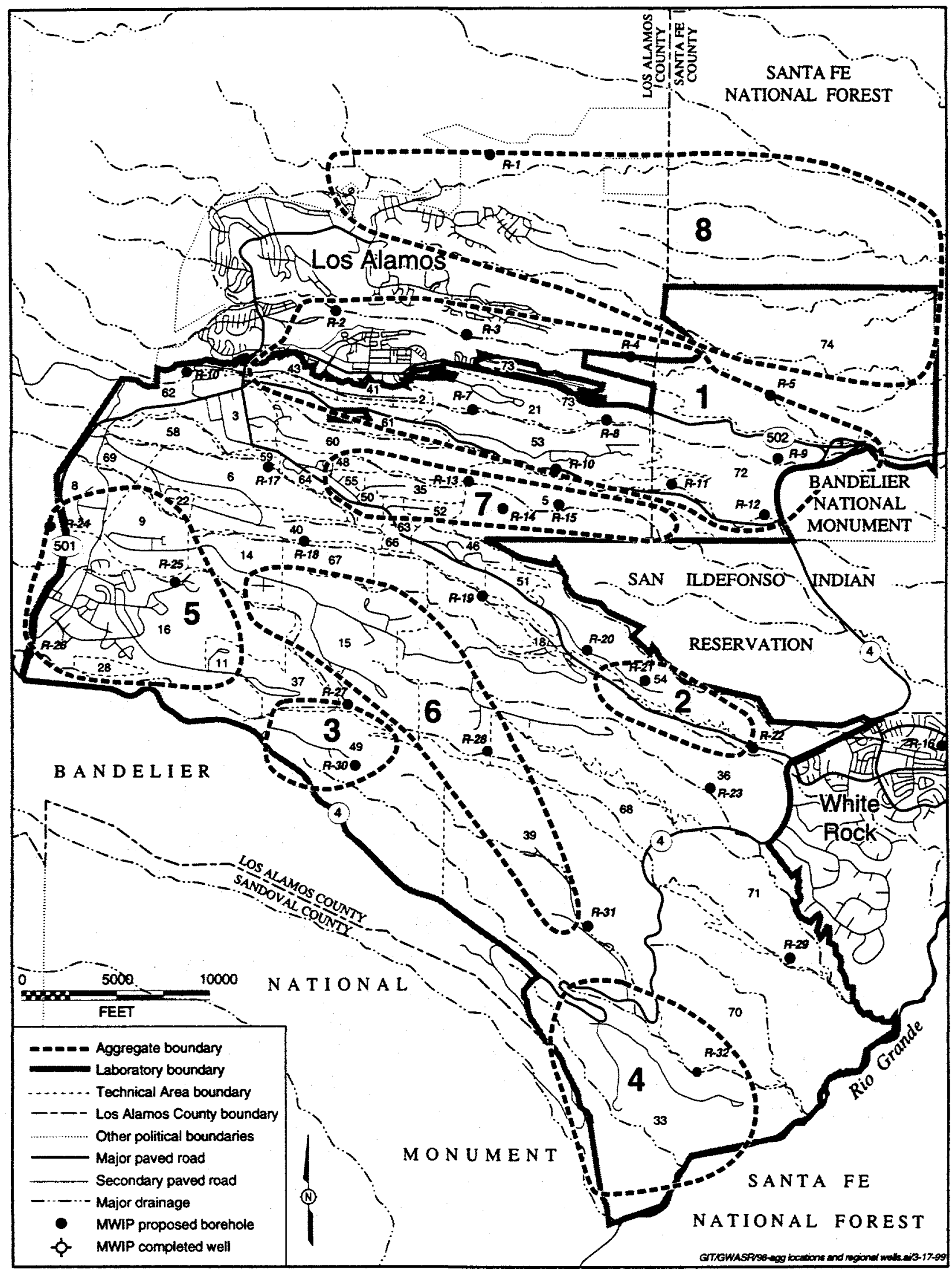

Figure 4-1. Locations of aggregates and MWIP regional aquifer wells and proposed boreholes. 


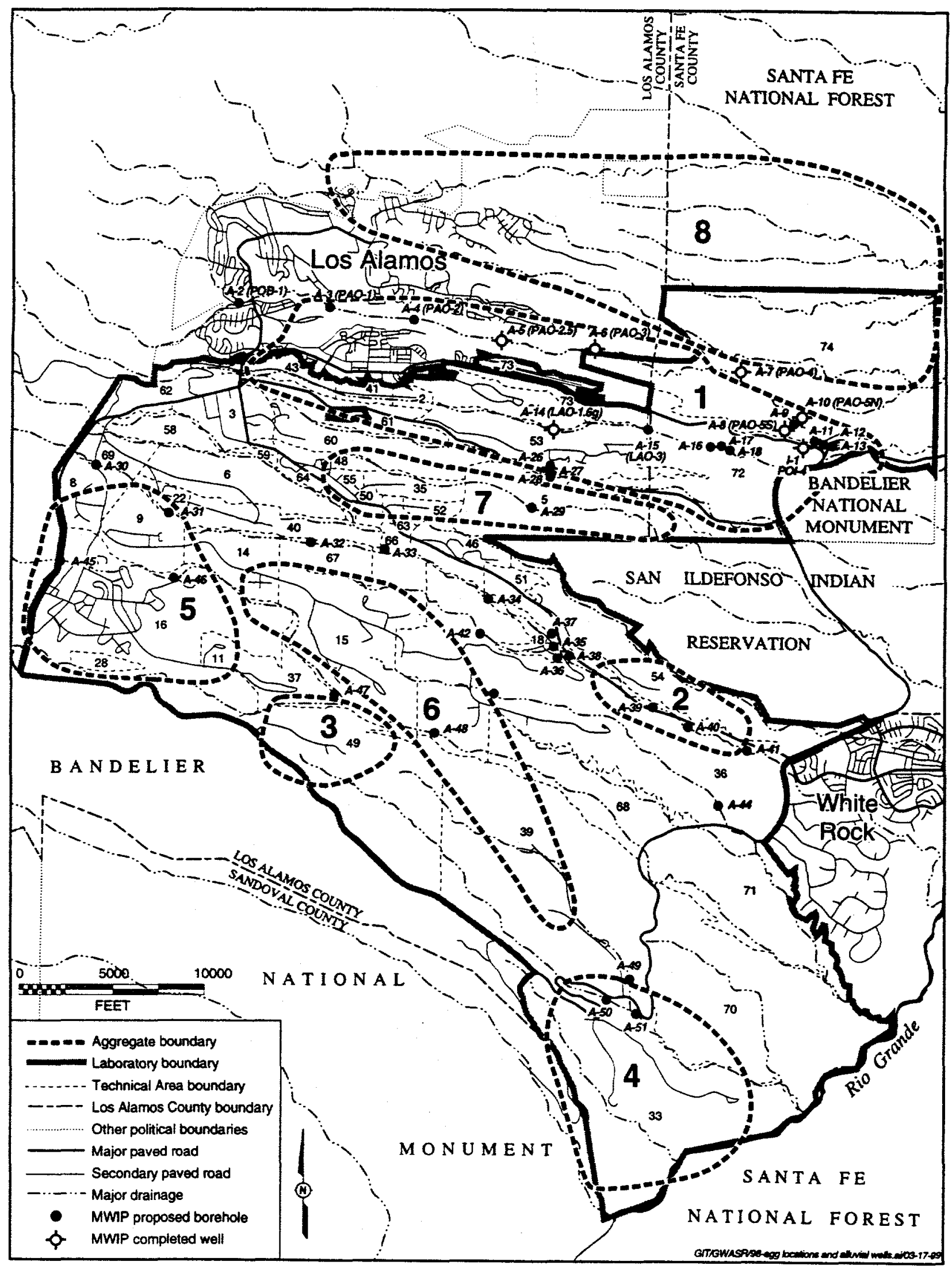

Figure 4-2. Locations of aggregates and proposed MWIP alluvial wells. 


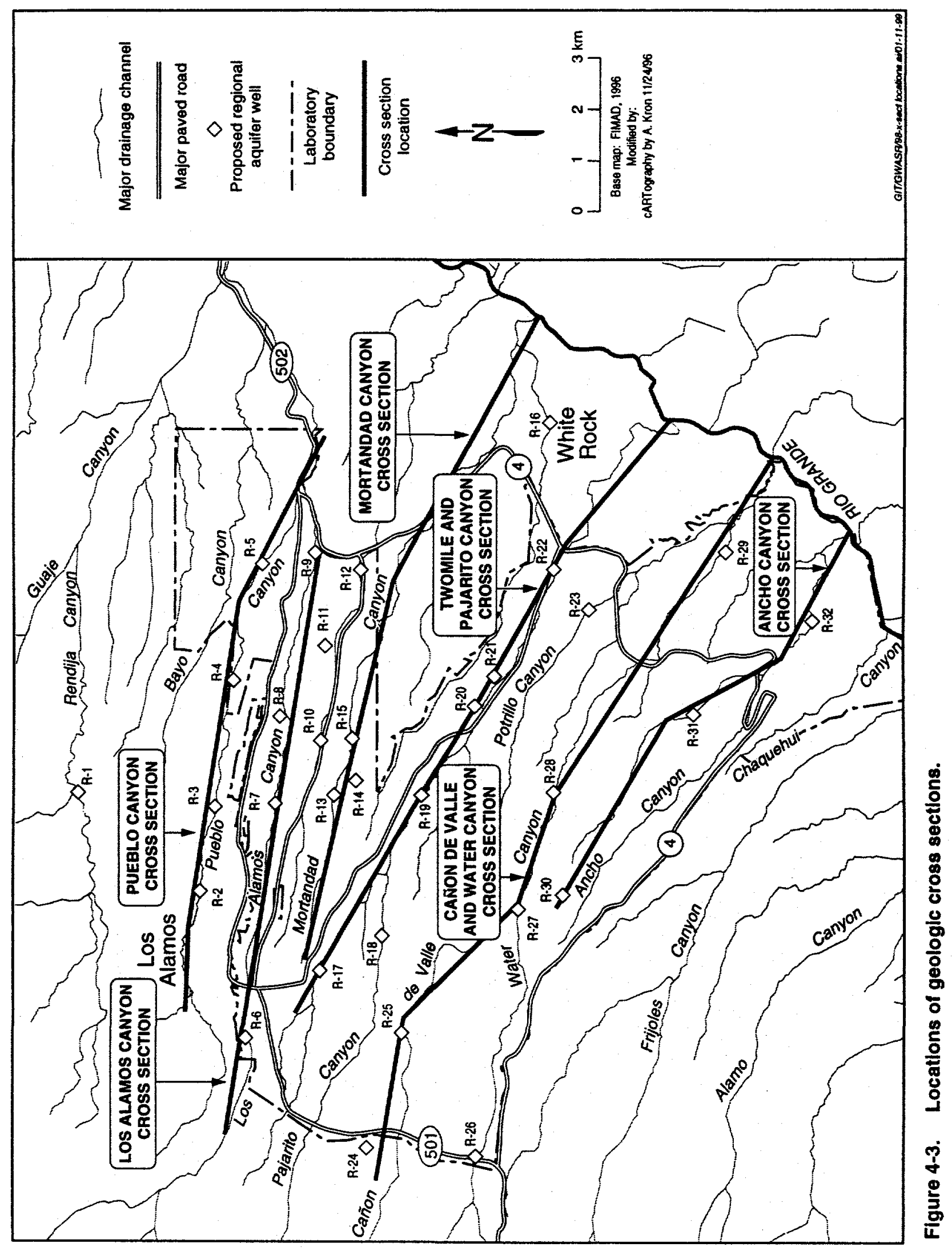




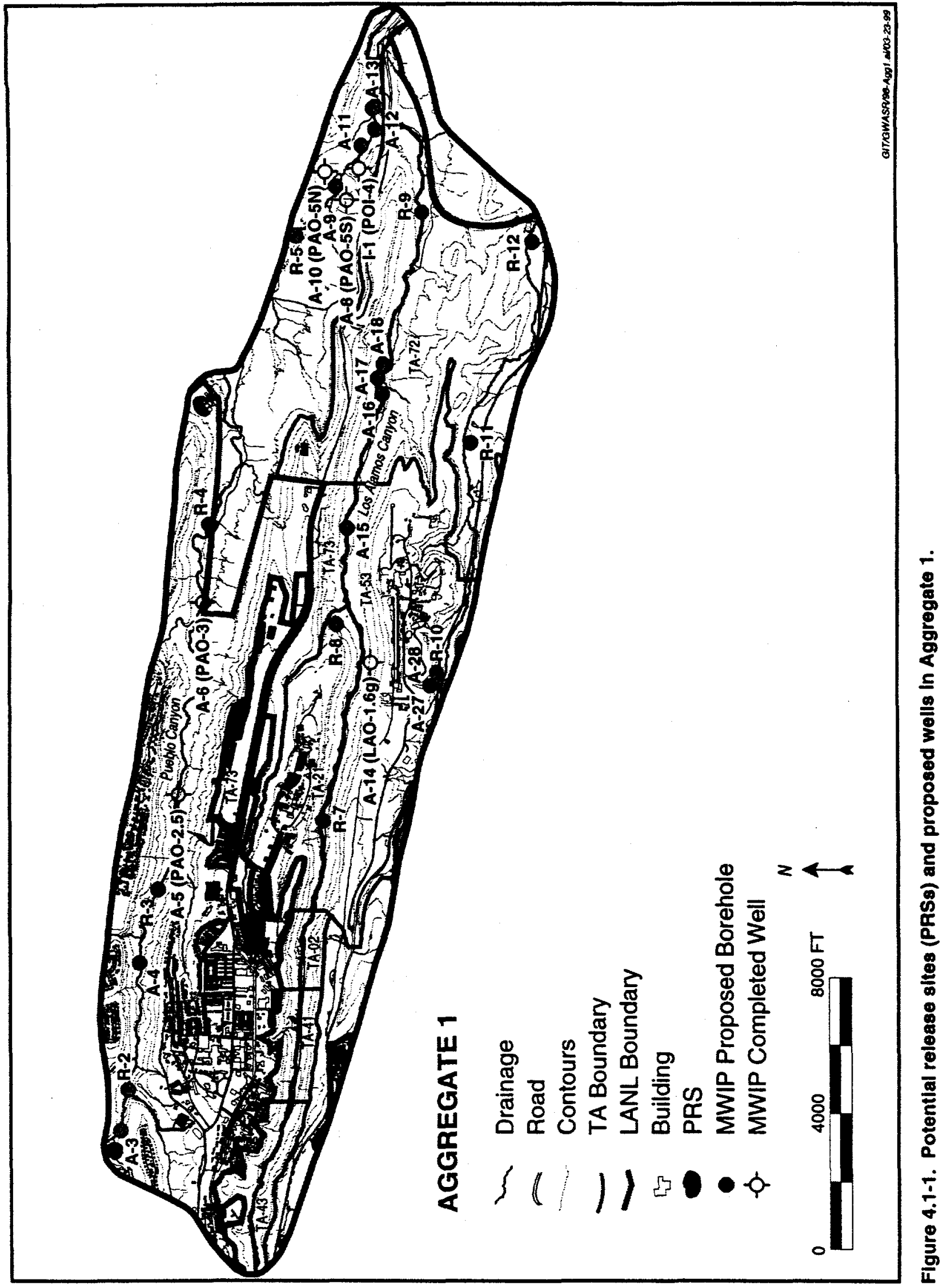




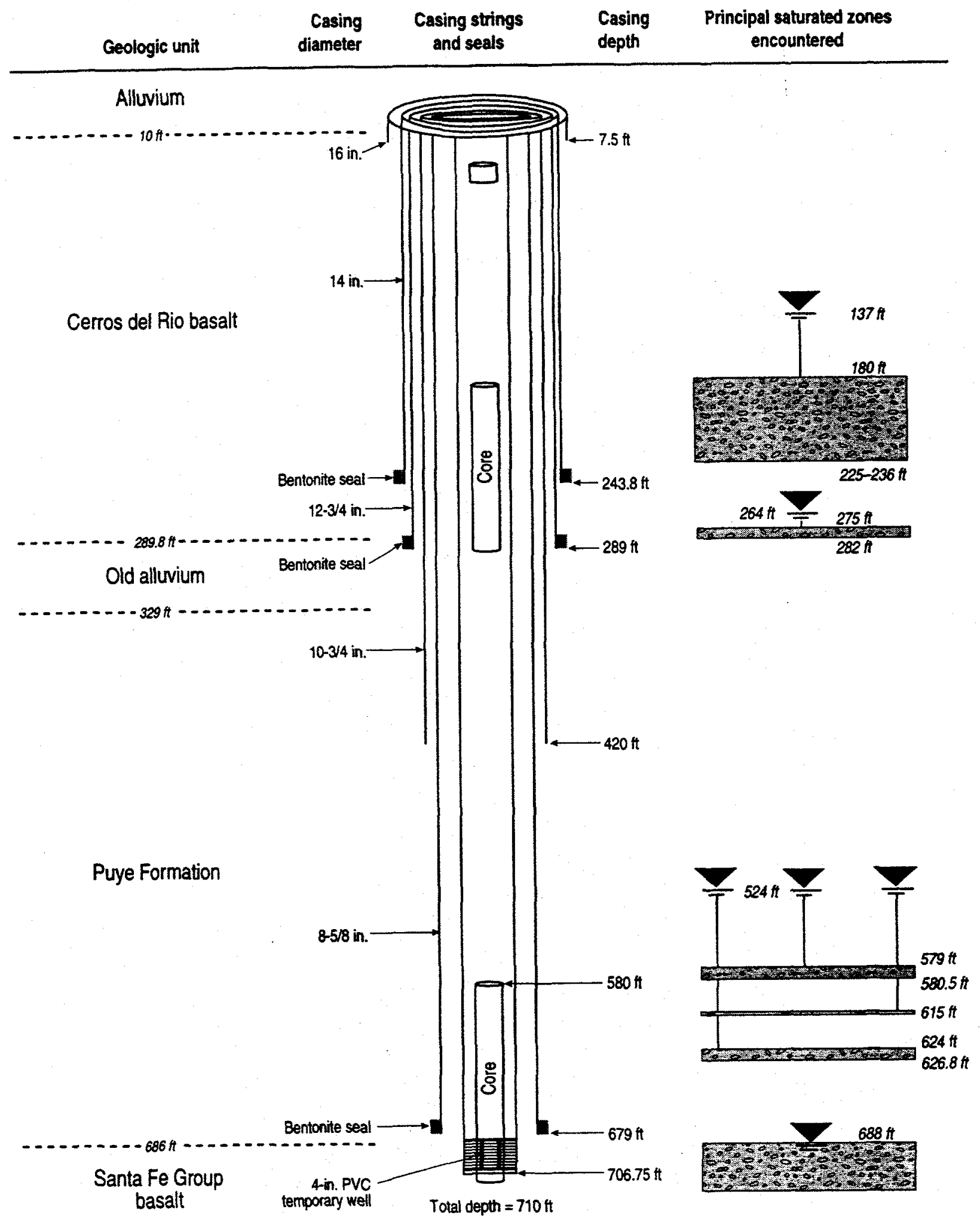

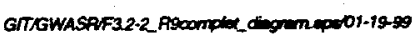

Figure 4.1-2. Configuration of R-9 as of January 30, 1998. 

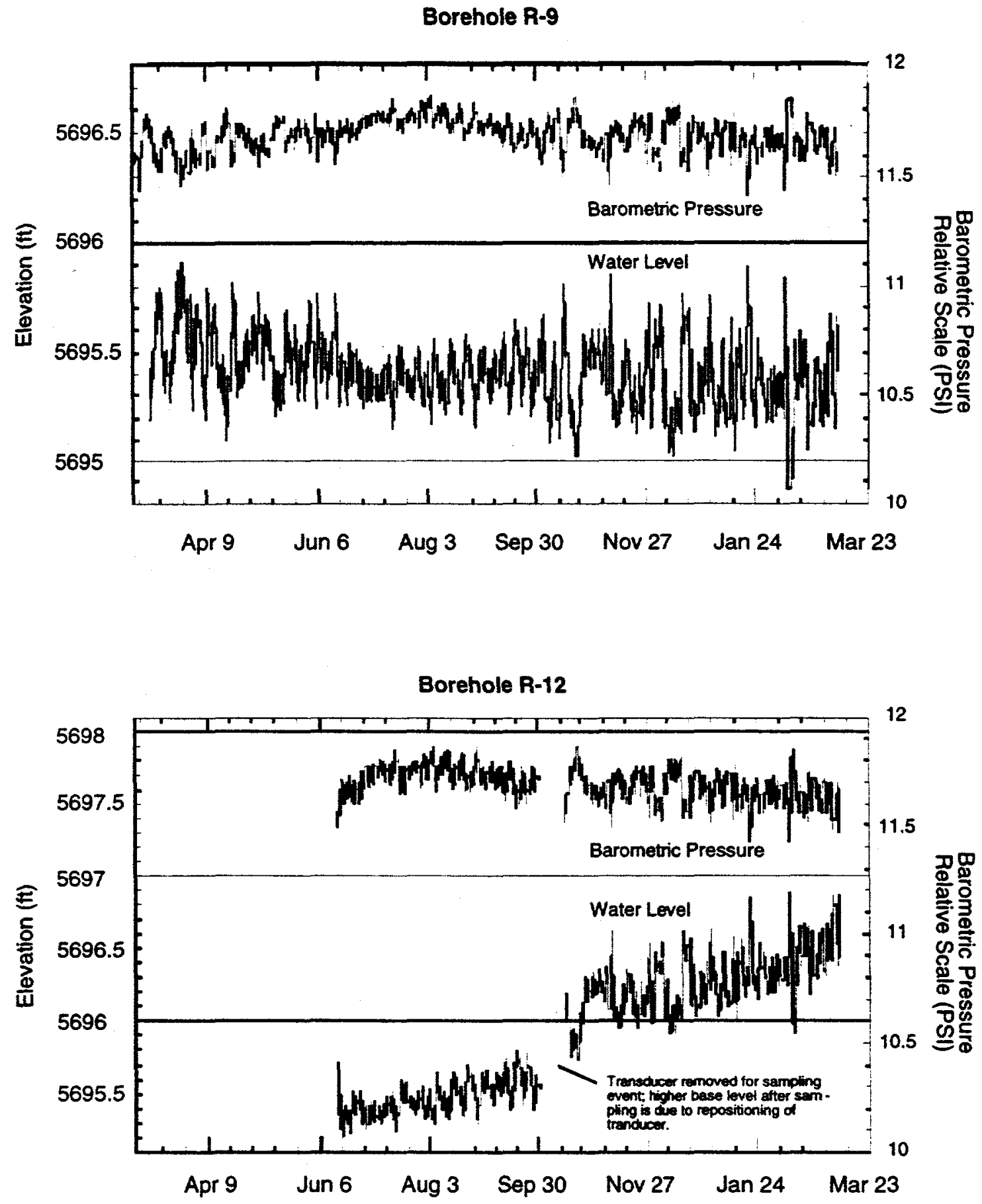

Figure 4.1-3. Water level and barometric pressure readings from boreholes R-9 and R-12. 


\section{Borehole R-12}

Characterization borehole R-12, located in Sandia Canyon near the eastern boundary of the Laboratory, is the second of approximately 32 wells being installed in the regional aquifer as part of the Laboratory's Hydrogeologic Workplan (LANL 1998). Borehole R-12 was funded by the Laboratory's ER Project and is primarily designed to provide water quality and water level data for potential intermediate-depth perched zones and for the regional aquifer. Borehole R-12 is downgradient of multiple contaminant source areas that potentially include release sites in the upper Sandia Canyon, Los Alamos Canyon, and Mortandad Canyon watersheds. Borehole R-12 is also sited to provide early warning for contaminants approaching water supply well PM-1 and to provide hydrologic and geologic data that contribute to the understanding of the vadose zone and regional aquifer in this part of the Laboratory. Although located in Sandia Canyon, R-12 is presented as part of the Aggregate 1 discussion because it was installed as part of the Work Plan for Los Alamos Canyon and Pueblo Canyon. A summary of R-12 drilling results is summarized below. A more in-depth description of R-12 drilling and testing activities is presented in Broxton et al. (1998A).

Figure 4.1-4 shows the current completion status of R-12.

- Borehole R-12 was drilled to a total depth of $847 \mathrm{ft}$ using air-rotary techniques. Drilling methods included downhole percussion hammers and dual-wall casing to drill open hole, a continuous coring system to core open hole, and Holte/Stratex casing advance systems that operated on dual-wall casing and downhole percussion hammers. In descending order, geologic units penetrated in R-12 included alluvium, tephras and volcaniclastic sediments of the Cerro Toledo interval, Otowi Member of the Bandelier Tuff, basaltic rocks of the Cerros del Rio volcanic field, old alluvium, Puye Formation, and basaltic rocks of the Santa Fe Group.

A perched groundwater system was encountered from depths of 443 to $519 \mathrm{ft}$ in the lower part of the Cerros del Rio basalt and in underlying old alluvium. Groundwater in this zone was confined and the water level stabilized at a depth of $424 \mathrm{ft}$ after the top of the zone was penetrated. The confining layer at the top of this zone apparently is massive basalt, and the lower perching layer is a clay-rich lacustrine deposit. The saturated thickness of this groundwater body is approximately $75 \mathrm{ft}$, making it one of the thickest intermediate-depth perched groundwater bodies identified yet on the eastem side of the Pajarito Plateau.

- The regional water table was encountered at a depth of $805 \mathrm{ft}$ in fractured basalt of the Santa Fe Group. The water is unconfined and occurs at the same elevation as at R-9, located approximately $1 \mathrm{~km}$ to the north. The elevation of the water table in R-12 is approximately $62 \mathrm{ft}$ lower than the static water level in nearby supply well PM-1 under nonpumping conditions.

- Groundwater samples were collected from the perched zone at depths of 443,464 , and $495 \mathrm{ft}$. These samples were chemically characterized with respect to major ions, trace elements, dissolved organic carbon, stable isotopes, tritium, and other radionuclides. Groundwater compositions are similar for the samples collected at depths of 443 and $495 \mathrm{ft}$, but the groundwater sampled at $464 \mathrm{ft}$ has a distinctive chemistry.

Groundwater from the perched zone is dominantly a calcium-sodium-bicarbonate-chloride type as represented by the samples collected at depths of 443 and $495 \mathrm{ft}$. There is also a sodiumcalcium-chloride-sulfate-bicarbonate groundwater at a depth of $464 \mathrm{ft}$. Groundwater from the depths of 443 and $495 \mathrm{ft}$ was found to contain 249.3 to $254.7 \mathrm{pCil}$ tritium (analysis by low-level electrolytic enrichment), 31.5 to 33.4 parts per million (ppm) chloride, $<0.02$ to $0.26 \mathrm{ppm}$ ammonium, 4.9 to $5.5 \mathrm{ppm}$ nitrate, and 2.46 to 2.51 parts per billion (ppb) uranium. Groundwater from the depth of $464 \mathrm{ft}$ was found to contain $208.1 \mathrm{pCi} / \mathrm{L}$ tritium, $200 \mathrm{ppm}$ chloride, $13.5 \mathrm{ppm}$ ammonium, $0.21 \mathrm{ppm}$ nitrate, and $2.04 \mathrm{ppb}$ uranium. 


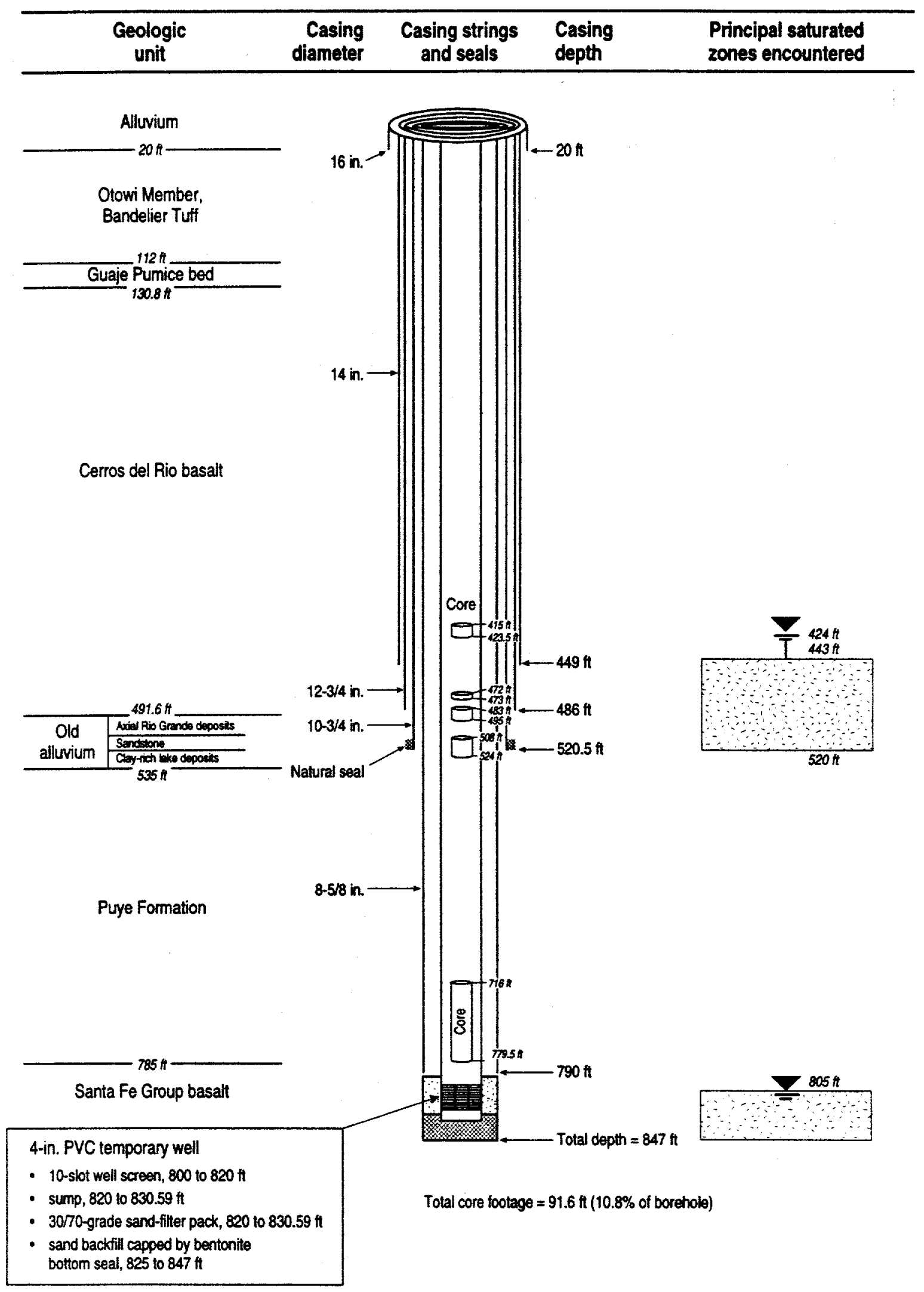

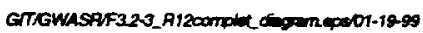

Figure 4.1-4. Configuration of R-12 as of June 10, 1998. 
Groundwater at the top of the regional saturated zone is a calcium-sodium-bicarbonate type with a total dissolved solids content of $386 \mathrm{ppm}$. The major cation and anion chemistry of this water is similar to groundwater in supply wells PM-1 and PM-3. The tritium activity in the regional saturated zone is $46.9 \mathrm{pCilL}$.

Borehole R-12 was completed as a temporary well so that additional data could be collected before a completion strategy is finalized. One concern was that the well design should include the ability to measure water level fluctuations, particularly given the proximity to supply well PM-1. Also, the decision to install a temporary well gave investigators time to collect more comprehensive information about potential contaminants and their concentrations at this location before deciding on a completion strategy. $R-12$ is a boundary well potentially downgradient from Mortandad Canyon and the well completion strategy could not be adequately addressed with out the additional data.

The change in static water level at the top of the regional aquifer in the R-12 borehole was recorded for a 9-month period from June 16, 1998 to March 8, 1999. The water level measurements were taken with a transducer that was placed inside the 4 inch PVC casing and screen which was temporarily installed in borehole R-12. Water level and atmospheric pressure were recorded on a 15-minute interval. No water level measurements were taken over the period from October 1, 1998 to October 15, 1998. During this time period the transducer was removed from the temporary well so that a bailer could be used to develop the well and collect groundwater samples. Figure 4.1-3 shows the relationship between atmospheric pressure and the static water level in the regional aquifer. A rise in atmospheric pressure results in a lowering of the static water level. Conversely, the static water level rises during periods when the atmospheric pressure decreases. As shown on Figure 4.1-3, the change in atmospheric pressure over a period of a few days in February, 1999 resulted in a 1 foot change in the static water level, similar to the result for water level change in R-9. A preliminary analysis of the water level record collected in borehole R-12 indicates the static water level at the top of the regional aquifer rose a distance of approximately 0.5 feet over the 9 month period of measurement. The effect of pumping at PM-1 on seasonal water levels in R-12 can not be evaluated until additional water level data are collected. However, the preliminary measurements suggest that the regional aquifer at R-12 does not respond in a discernable manner to withdrawal of water from PM-1.

\section{Alluvial Groundwater Investigations}

Four alluvial wells were installed in middle and lower Pueblo Canyon during FY98. These alluvial wells, which included PAO-2.5, PAO-3, PAO-5N, and PAO-5S, were installed by hollow stem auger. Figures 4.1-5 and 4.1-6 show the locations of these wells. The purpose of these wells is to determine groundwater chemistry and monitor groundwater quality upgradient and downgradient of discharges from the Los Alamos County Bayo Sewage Treatment Plant; determine continuity of alluvial groundwater in middle Pueblo Canyon; provide water level information for water balance analyses; and provide alluvial groundwater chemistry data to assess potential sources of recharge to intermediate-depth groundwater zones. Some information for each of these wells is given below. A more in-depth description of these wells is provided in Gray (1998).

- $\quad$ Alluvial well PAO-2.5 is located in middle Pueblo Canyon, approximately 12,350 ft west of the Los Alamos County Bayo Sewage Treatment Plant. The stratigraphy encountered included alluvial sediments (0-7.7 $\mathrm{ft}$ below ground surface [bgs]) and the Otowi Member of the Bandelier Tuff $(7.7-13.9 \mathrm{ft}$ bgs). The water level was $3.8 \mathrm{ft}$ bgs during drilling of initial borehole, but the well was dry after installation. 


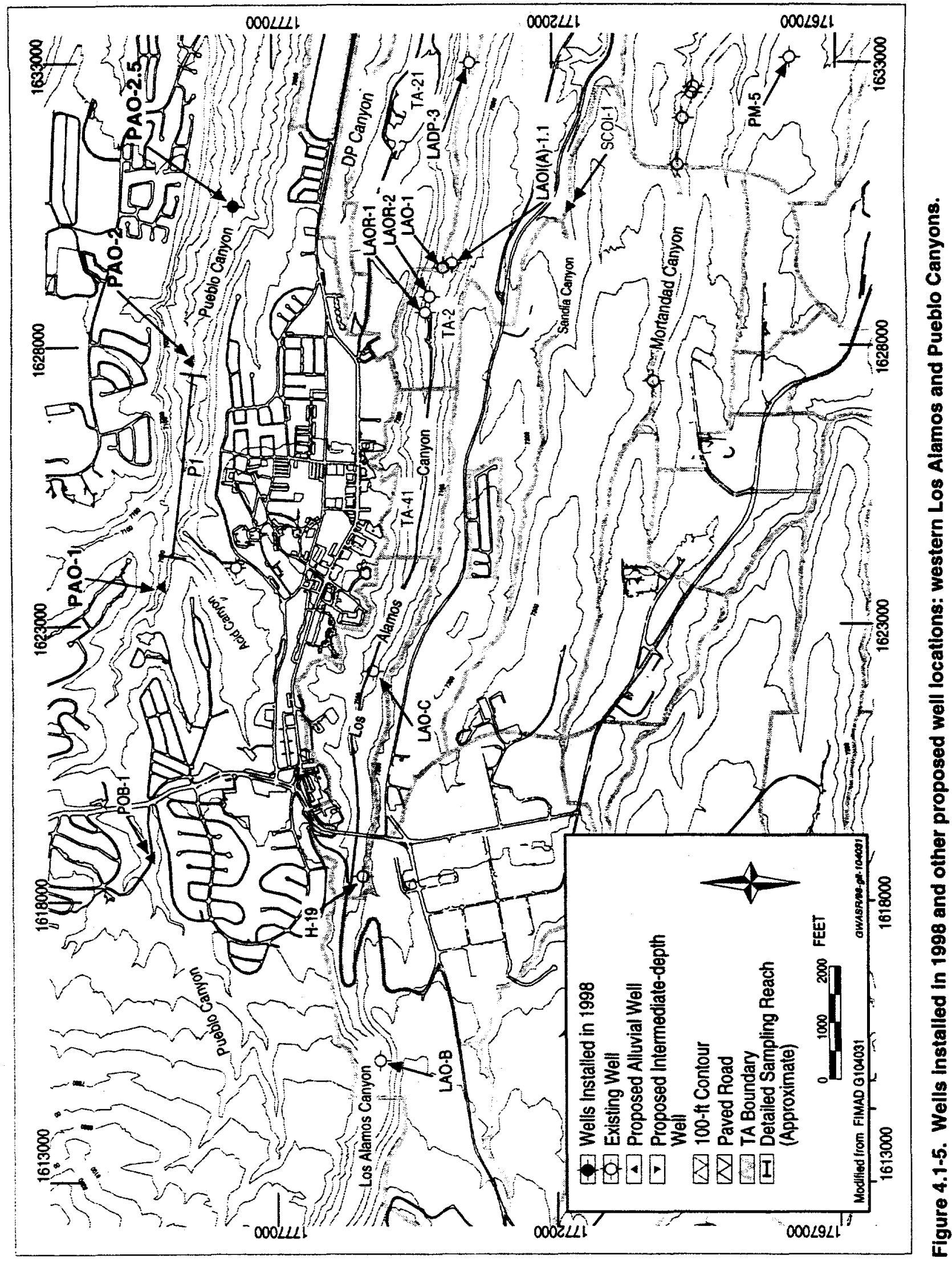




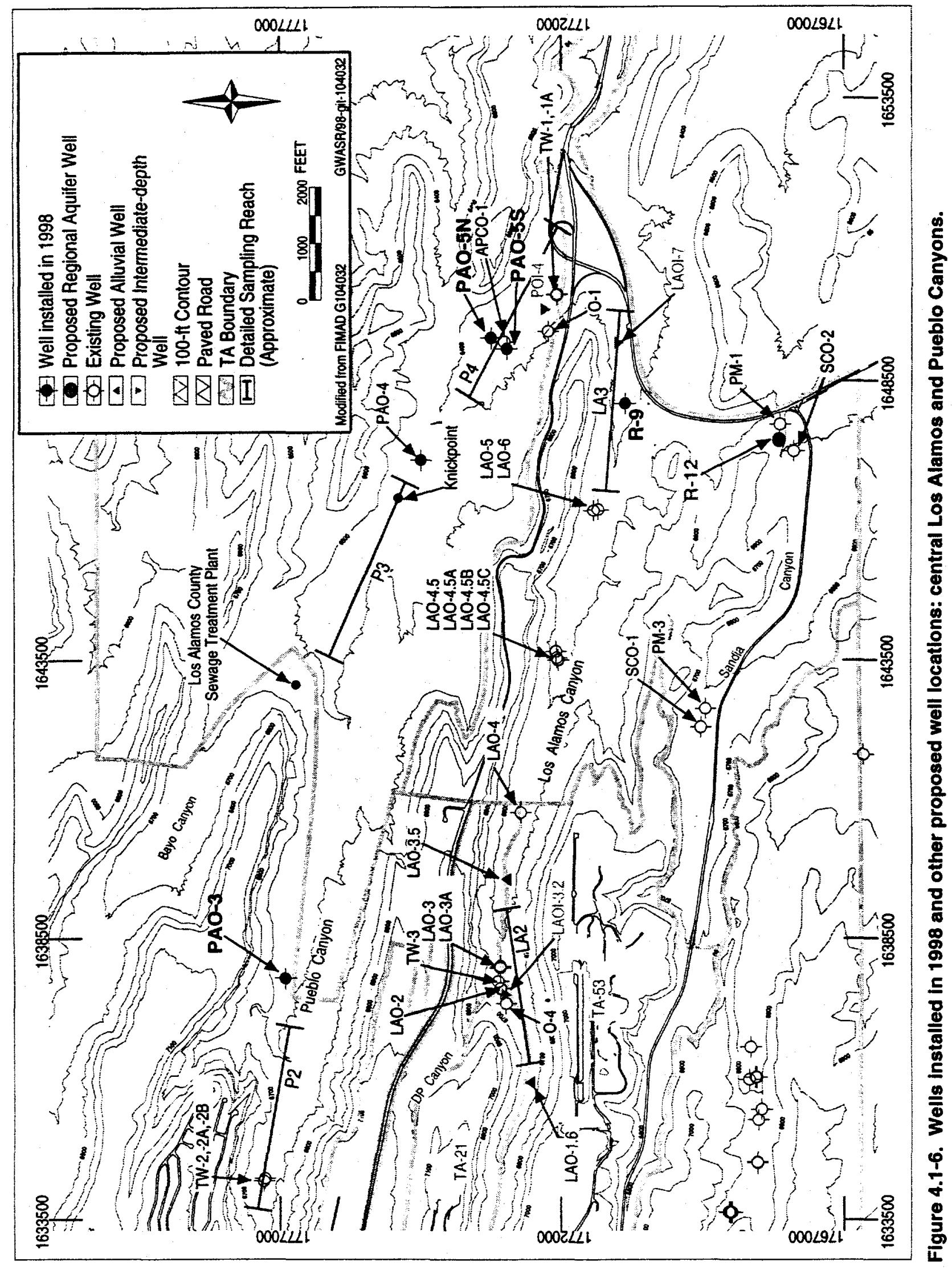


Alluvial well PAO-3 is located in middle Pueblo Canyon, approximately $5,200 \mathrm{ft}$ west of the Los Alamos County Bayo Sewage Treatment Plant. The stratigraphy encountered included alluvial sediments (0-10.8 $\mathrm{ft}$ bgs) and the Otowi Member of the Bandelier Tuff (10.8-17.5 $\mathrm{ft}$ bgs). The water level was $6 \mathrm{ft}$ bgs during drilling of initial borehole, but the well went dry after bailing during attempted development activities.

$\bullet$

Alluvial well PAO-5S is located in lower Pueblo Canyon, approximately $800 \mathrm{ft}$ north-northwest of the Otowi-1 supply well, and approximately $1800 \mathrm{ft}$ northwest of the White Rock " $\mathrm{Y}$ ". This well is part of a transect that includes wells PAO-5N and APCO-1 designed to determine lateral extent of alluvial sediments and groundwater in lower Pueblo Canyon. The stratigraphy encountered included alluvial sediments (0-5.3 ft bgs) and the Puye Formation (5.3-20 ft bgs). The water level was $7 \mathrm{ft}$ bgs during drilling but the well was dry after installation.

Alluvial well PAO-5N is located in lower Pueblo Canyon, approximately $170 \mathrm{ft}$ north-northeast of well PAO-5S, approximately $950 \mathrm{ft}$ north-northwest of the Otowi-1 supply well, and approximately $1700 \mathrm{ft}$ northwest of the White Rock " $Y$ ". The stratigraphy encountered included alluvial sediments $(0-18.0 \mathrm{ft} \mathrm{bgs})$ and the Puye Formation (18.0-22.5 ft bgs). The water level was $7 \mathrm{ft}$ bgs during drilling and well development.

\section{Airport Landfill (TA-73)}

The ER Project has been investigating a former municipal landfill near the Los Alamos airport since 1994. This investigation has spanned multiple media and potential contaminants, which resulted in a large database (approximately 64,000 records) of environmental chemical information for this landfill. The RFI report submitted to NMED in FY98 presented data for this project, which included statistical evaluations of chemical distributions of contaminants. The RFI report also provided a detailed discussion and information on the nature and extent of contamination and presented qualitative information on contaminant fate and transport. Other information included in the RFI report consisted of calculations of human health risk, developed a site-specific screening-level ecological risk assessment, and mostly importantly documented these findings in an appropriate and technically defensible report. There was no transport modeling of these data in the RFI report, but the conceptual model suggests that vapor phase transport of organic chemicals could be a potential pathway of contaminants to groundwater. The conceptual model also suggested that infiltration of precipitation through the waste into the vadose zone was not a likely groundwater transport pathway. Further action at the airport landfill was recommended to mitigate areas of surface contamination and potential human exposure to landfill gasses.

\section{DP Canyon (TA-21)}

Quarterly groundwater sampling was conducted in DP Canyon at alluvial monitoring wells LAUZ-1 and LAUZ-2 (Locations 21-01811 and 21-01812, respectively) and DP Spring (Location 21-01854). The 2nd, 3 rd, and 4th quarter samples were collected during FY98. The sampling was conducted in fulfillment of the sampling and analysis plan that is being implemented as an addendum to the Work Plan for Los Alamos Canyon and Pueblo Canyon. Filtered samples from these locations were analyzed, at a minimum, for isotopic plutonium, isotopic uranium, strontium-90, cesium-137, tritium, and target analyte list (TAL) metals. Untiltered samples were analyzed, at a minimum, for isotopic plutonium, isotopic uranium, strontium-90, cesium-137, tritium, TAL metals, pesticides and polychlorinated biphenyis, SVOCs, and VOCs.

Analytical results from these sampling events indicate that only strontium-90 was detected at activities exceeding the NMED MCL for drinking water ( 8 pCir). 


\section{Upper Sandia Canyon}

The first phase of a sediment investigation in upper Sandia Canyon was completed in FY98. The investigation is being managed by the Remedial Actions Focus Area with the technical lead provided by the Canyons Focus Area. The first phase of the investigation involved mapping of the upper canyon (Reaches S-1 and S-2) and analysis of 72 sediment samples collected from the key geomorphic units identified during the mapping process. Validated results of the first phase of sampling were received in early FY99 and will be used to guide the second phase sampling currently scheduled for FY00. Two quarters of baseflow surface water sampling have been conducted in upper Sandia Canyon. The remaining two quarters will be completed in FY99.

\section{Aggregate 1 Geochemistry Findings}

\section{Oxalate in Surface Waters, Groundwaters, and Soils}

Oxalate has been identified in groundwater in borehole R-9, upper Los Alamos Canyon (Broxton et al., 1998). The origin(s) and distribution of oxalate at R-9 and elsewhere around the Laboratory are uncertain and are currently being investigated. This section provides a summary of oxalate distributions in soils, surface water, vadose zone core samples, and groundwater at the Laboratory and surrounding areas, and it provides a preliminary interpretation of the oxalate's origin.

Approximately 195 groundwater samples, 23 surface water samples and nine background soil samples have been analyzed for anions including oxalate. Groundwater samples were collected from 1996 through 1998 and surface water and soil samples were collected in 1998. In addition, groundwater samples have been analyzed for major cations, trace elements, and trace metals as part of the LANL background water investigation. Surface water samples were collected from the Rio Grande, Mortandad Canyon, upper Sandia Canyon, Pajarito Canyon, DP Canyon, Acid Canyon, Pueblo Canyon, and upper Los Alamos Canyon. Groundwater samples were collected from the following locations: Los Alamos Canyon (alluvium, perched intermediate zones, and regional aquifer), Guaje Canyon (regional aquifer), Sandia Canyon (perched intermediate zone[s] and regional aquifer), Mortandad Canyon (alluvium and regional aquifer), White Rock Canyon springs (perched intermediate zones and regional aquifer), and LANL background springs (perched intermediate zones and regional aquifer) located west and north of the Laboratory. In addition, vadose zone core samples from TA-54, TA-21, TA-49, and borehole R-9 have been analyzed for oxalate and other anions (Newman, 1999; Broxton et al., 1998). Samples have been analyzed from the Bandelier Tuff, the Cerro Toledo interval, the Cerros del Rio basalts, the Puye Formation, and the Santa Fe Group.

Oxalate is an organic acid that occurs naturally under specific oxidation-reduction conditions. In natural systems, oxalate is formed from the oxidation of carbohydrates $\left(\mathrm{CH}_{2} \mathrm{O}\right)$ present in organic-rich soils and, in turn, it can eventually oxidize to $\mathrm{CO}_{2}$ gas. In addition, fungi produce substantial quantities of oxalate in soil (Cromack et al., 1997; Graustein et al., 1977). Oxalate is stable under reducing conditions typical of wetlands, bays (Thurman, 1985), oil-field brines, O-horizon soils, and organic-rich soils found in the southeastern USA (Fox and Comerford, 1990). Above a pH value of 4.2, oxalate is stable as $\mathrm{C}_{2} \mathrm{O}_{4}{ }^{2-}$ (Drever, 1988), which is mobile in groundwater and surface water under near-neutral pH conditions. Oxalate precipitates from solution forming minerals with divalent metals including calcium, magnesium, and the uranyl cation, $\mathrm{UO}_{2}{ }^{2+}$. Calcium-oxalate minerals (whewelite and weddellite) associated with fungi and plant roots almost certainly occur in fractures on the Pajarito Plateau (Newman et al., 1997; Reneau and Vaniman, 1998). The oxalate anion can be an excellent tracer under oxidizing conditions due to its mobility in aqueous systems. 
Oxalate is also produced industrially for metal extraction processing. Oxalate was used at former TA-1 (LA 1100 report, 1947) and TA-21 in the processing uranyl oxalate $\left(\mathrm{UO}_{2} \mathrm{C}_{2} \mathrm{O}_{4}\right)$ and plutonium oxalate $\left(\mathrm{Pu}\left[\mathrm{C}_{2} \mathrm{O}_{4}\right]_{2}\right.$ and $\mathrm{Pu}_{2}\left[\mathrm{C}_{2} \mathrm{O}_{4}\right]_{3}$ ). The solubility of $\mathrm{UO}_{2} \mathrm{C}_{2} \mathrm{O}_{4}$ is approximately $5,000 \mathrm{mg} / \mathrm{L}$. Waste solutions containing uranium and oxalate probably were discharged into upper Los Alamos Canyon and DP Canyon since the 1940s. Discharges containing oxalate, nitrate, chloride, and sulfate may have migrated to the top of the regional aquifer at borehole R-9.

Concentrations of oxalate within soil extracts, surface water samples, and groundwater samples were determined by ion chromatography at EES-1. The detection limit for oxalate using ion chromatography is $0.02 \mathrm{mg} / \mathrm{L}$ or ppm. Analytical precision of Dionex ion chromatograph is better than $5 \%$. Both non-acidified filtered and non-filtered water samples were collected for oxalate analysis. Soil samples were dried for 12 hours at $100^{\circ} \mathrm{C}$ prior to leaching. For the soil samples, $75 \mathrm{ml}$ of deionized water were added to $75 \mathrm{~g} \mathrm{dry}$ soil forming a 1:1 water-soil slurry. The slurry was shaken for 24 hours on a rotary mixer and filtered prior to chemical analysis. Vadose-zone core samples were prepared in a similar manner as the soil samples.

Only eight of the 195 groundwater samples contained measurable oxalate. All eight samples were collected from borehole R-9 in 1997 and 1998. These included four filtered and four non-filtered samples collected from perched intermediate zones $(275,615$, and $624 \mathrm{ft})$ and the regional aquifer (688 $\mathrm{ft})$. Concentrations of oxalate in R-9 groundwater range from 0.30 to 3.03 ppm (Broxton et al., 1998). The remaining 187 groundwater samples did not contain measurable oxalate. These samples are representative of both background and Laboratory-effluent waters.

Only one of the nine background soil samples contained oxalate. The sample was a topsoil sample collected from a grassland area near the ski hill road and state road NM 501 intersection and contained $0.5 \mathrm{ppm}$ oxalate. None of the 23 surface water samples contained oxalate.

Every borehole examined for vadose-zone oxalate contained some oxalate, however it is not uniformly distributed. Pore-water concentrations range from below detection to about $200 \mathrm{mg} / \mathrm{L}$. In R-9, the vadose zone above the first saturated zone (180 ft) in the Cerros del Rio basalts has the largest oxalate concentrations (Broxton et al., 1998). The Puye Formation also contains relatively large amounts of oxalate. In general, vadose zone oxalate concentrations in R-9 are similar to those in the other boreholes.

Even though oxalate is commonly found in the vadose zone at Los Alamos, the relatively high concentrations in the saturated zones at R-9, coupled with below detection-limit concentrations in all other groundwater samples, strongly suggests that the oxalate measured in groundwaters encountered at borehole R-9 is Laboratory derived. In addition, oxalate occurs with uranium in groundwater samples collected from borehole R-9 (Broxton et al., 1998). Co-location of uranium and oxalate is consistent with the fact that at former TA-1, in the earty 1940s, natural uranium ore was initially digested in nitric acid and precipitated as uranyl oxalate prior to forming $\mathrm{U}_{3} \mathrm{O}_{3}(\mathrm{LA}-1100,1947)$. Residual uranium and oxalate were discharged to upper Los Alamos Canyon, based on sampling results for perched intermediate groundwater and the regional aquifer (R-9). Concentrations of oxalate in the R-9 core samples and saturated zones vary with depth, suggesting that multiple flow paths may exist and changes in vertical recharge with time may have occurred in upper Los Alamos Canyon.

\section{Geochemical Modeling Predictions of Uranium Mobility in the Regional Aquifer}

Geochemical modeling was conducted for borehole R-9 using the computer code, MINTEQA2 (Allison et al., 1991) to quantify adsorption of uranium (uranyl) onto HFO. In the past, surface complexation modeling of uranium and other solutes has not been performed on groundwaters and aquifer materials 
found at LANL. These simulations should improve our understanding of how natural solutes and contaminants (actinides and fission products) adsorb onto solids. Adsorption is the dominant process influencing the fate and transport of both trace natural solutes and contaminants in groundwater. Desorption processes can also be evaluated through both experimental investigations and surface complexation modeling. Adsorption modeling can be applied to evaluating intrinsic remediation and risk analysis.

Groundwater was encountered in a lower perched zone ( $275 \mathrm{ft}$ depth) within the basalt at borehole R-9. This perched groundwater has a pH of 8.8 and is characterized by a sodium-bicarbonate ionic composition (Broxton et al. 1998). Suspended uranium concentrations are $112 \mu \mathrm{g} /(0.112 \mathrm{mg} / \mathrm{kg})$ in this perched zone. Dissolved uranium concentrations of $48.4 \mu \mathrm{g} /(0.0484 \mathrm{milligram} / \mathrm{liter})$ were also observed. The proposed EPA MCL for uranium in drinking water is $20 \mu \mathrm{g} /$. Background concentrations of dissolved uranium at Los Alamos are typically less than $1 \mu \mathrm{g} / \mathrm{l}$ within basalt. Uranyl forms strong (soluble) complexes with bicarbonate and carbonate under alkaline $\mathrm{pH}$ conditions (Langmuir, 1997). Uranium was analyzed by inductively coupled plasma mass spectrometry (ICPMS) at CST-7.

Adsorption processes for uranium can be represented by measuring or calculating a distribution coefficient $\left(\mathrm{K}_{d}\right)$. The $\mathrm{K}_{\mathrm{d}}$ is the amount of species (uranium) sorbed per mass of sorbent (typically silts, clays, or oxides within the aquifer) divided by concentration of solute (uranium) in solution (Langmuir, 1997). Higher $K_{d}$ values correspond to increasing sorption onto solid materials or lower mobility in aqueous solution. For the lower perched zone in R-9, a calculated $K_{d}$ for uranium is $0.112(\mathrm{mg} / \mathrm{kg}) / 0.0484$ $(\mathrm{mg} / \mathrm{l})$, which is equal to $2.3 \mathrm{l} / \mathrm{kg}$. This low $K_{0}$ value implies that uranium (uranyl) is mobile under alkaline and oxidizing conditions characteristic of the lower perched zone.

The diffuse layer model (DLM) was selected to quantify adsorption of the uranyl cation $\left(\mathrm{UO}_{2}{ }^{2+}\right)$ onto $\mathrm{HFO}$. HFO may occur as surface coatings present on basaltic glass and clay minerals identified in core samples collected from R-9. The DLM considers solution speciation and aqueous ion activities. The DLM is more rigorous than the $\mathrm{Kd}$ model because it includes sorbent (solid material) properties such as surface area and concentration, and groundwater composition such as $\mathrm{pH}$ and solute concentration. The model uses the electric double-layer theory that assumes that the positive or negative surface charge of a sorbent, in this case HFO, in contact with solution generates an electrostatic potential that declines rapidly away from the sorbent surface (Langmuir, 1997). The potential is the same at the zero (sorbent surface) and d (solution) planes.

Results of the adsorption modeling simulation using the DLM suggest that, in the lower perched zone, $57.5 \%$ of uranyl ( $64 \mu \mathrm{g} /$ sorbed uranium) is bound as a surface complex, $\mathrm{SO}_{2} \mathrm{UO}_{2}{ }^{+}$, where $\mathrm{SO}_{2}$ represents a weak sorption surface site on HFO. Dissolved (non sorbed) uranium is predicted to occur both as $\mathrm{UO}_{2}\left(\mathrm{CO}_{3}\right)_{2}{ }^{2 \cdot}$ at $5.1 \%(7 \mu \mathrm{g} / \mathrm{l})$ and as $\mathrm{UO}_{2}\left(\mathrm{CO}_{3}\right)_{3}{ }^{4}$ at $36.6 \%(41 \mu \mathrm{g} / \mathrm{l})$. The model simulation predicts $48 \mu \mathrm{g} / \mathrm{l}$ of dissolved uranium at a pH value of 9 . This is in excellent agreement with the measured dissolved uranium $(48.4 \mu \mathrm{g} / \mathrm{l})$ at $\mathrm{pH}$ 8.8. Uranyl complexation with bicarbonate and cabonate in the lower perched zone decreases the amount of adsorption by $41.7 \%$, which results in uranium concentrations exceeding the proposed EPA MCL of $20 \mu \mathrm{g} /$.

\section{Nitrogen Isotopes in Borehole R-12}

The main sources of nitrate found in groundwater and surface water at the Laboratory include (1) natural organic nitrogen in soils, (2) dissolved nitric acid discharges, (3) fertilizers, and (4) treated septic/effluent discharges. Of these possible sources, aqueous discharges of both dissociated nitric acid and treated septic/effluent probably exceed naturally- and fertilizer-derived nitrate. 
Water samples were collected from Borehole R-12 and from several other wells, springs, and NPDESpermitted outfalls within Los Alamos Canyon, Pueblo Canyon, Sandia Canyon and at TA-50. Samples were analyzed for ammonium, nitrate, and nitrogen-15/nitrogen-14. Analytical results of nitrogen species and isotopes are presented in Table 4.1-1.

Table 4.1-1. Summary of Nitrogen Chemistry and Nitrogen Isotopes for Several Waters in Sandia Pueblo, Los Alamos Canyon, and TA-50

\begin{tabular}{|c|c|c|c|c|c|}
\hline Location & $\mathrm{NO}_{3}+\mathrm{N}$ & $\mathrm{NH}_{4}-\mathrm{N}$ & Del ${ }^{1514} \mathrm{~N}^{-\mathrm{NO}}$ & Def $15 n N_{N}-N_{4}$ & Water Type \\
\hline$R-12(443 \mathrm{ft})$ & 4.9 & $<0.02$ & $15.2(3)$ & & perched \\
\hline$R-12(464 \mathrm{ft})$ & 0.21 & 13.5 & $21.3(2)$ & $1.3(2)$ & perched \\
\hline $\mathrm{R}-12(495 \mathrm{ft})$ & 5.5 & 0.26 & $20.3(2)$ & & perched \\
\hline$R-12(805 \mathrm{ft})$ & 0.46 & 0.02 & $11.3(2)$ & & regional \\
\hline$R-9(579 \mathrm{ft})$ & 2.4 & 0.07 & $3.0(2)$ & & regional \\
\hline $\begin{array}{l}\text { Stream below Bayo Sewage } \\
\text { Treatment Plant in Pueblo Canyon }\end{array}$ & & & $7.8(2)$ & & effluent \\
\hline TW-1A & $<0.02$ & 0.29 & $24.6(2)$ & & perched \\
\hline$T W-1$ & 5.3 & 0.04 & $17.2(3)$ & & regional \\
\hline Basalt Spring & 4.5 & 0.02 & $34.2(2)$ & & perched \\
\hline LA Spring & 2.8 & $<0.02$ & $2.8(2)$ & & perched \\
\hline TA-50 & 67.3 & 4.73 & $2.1(2)$ & & effluent \\
\hline TA-3 & 1.5 & 0.12 & $32.4(2)$ & & effluent \\
\hline $\mathrm{HNO}_{3}$ Std. $^{c}$ & 5.7 & $<0.02$ & $1.0(4)$ & & acid \\
\hline \multicolumn{6}{|c|}{$\begin{array}{l}\text { a. Concentrations of nitrate and ammonium in units of ppm; isotopes in units per mil or parts per thousand } \\
\text { b. Nitrogen isotopic analyses performed by Coastal Science Laboratories, Inc., Austin, Texas. The number of isotopic } \\
\text { analyses for each sample are given in parentheses. } \\
\text { c. Laboratory HNO, standard prepared at EES-1 }\end{array}$} \\
\hline
\end{tabular}

The isotopic standard for nitrogen-15/nitrogen-14 is nitrogen in air, which has a nitrogen-15/nitrogen-14 value of zero (Clark and Fritz 1997, 59168). Nitrate derived from treated septic effluent is enriched in nitrogen-15 and depleted in nitrogen-14 thereby characterized by positive nitrogen-15/nitrogen-14 ratios ( 7 to $>30$ per mil; Clark and Fritz 1997, 59168). During denitrification, which is the reduction of nitrate to nitrogen gas in the presence of organic carbon, residual nitrate becomes enriched in nitrogen-15. Subsequently, nitrogen-15/nitrogen-14 ratios become increasingly more positive with increasing denitrification.

Groundwater samples collected from borehole R-12 (at 443, 464, 495, and $805 \mathrm{ft}$ ), Basalt Spring, the TA-3 outfall, TW-1A, and TW-1 have nitrogen-15/nitrogen-14 values ranging from 11.3 to 34.2 per mil (Table 4.1-1). Possible sources of nitrate in these waters, based on their nitrogen isotopic analyses, is septic/effluent derived from sewage treatment plants. This is consistent with known sources of treated effluent discharge from the sewage treatment plant(s) in Pueblo Canyon and the TA-3 discharge in upper Sandia Canyon.

Nitric acid is produced by reacting ammonia gas with oxygen gas. Ammonia is oxidized to nitrate through a series of reactions involving nitrous oxide, nitric oxide, and nitric dioxide, which eventually produces nitric acid. Ammonia is initially produced by reacting nitrogen gas, having a nitrogen-15/nitrogen-14 ratio 
of zero per mil, with hydrogen gas. Consequently, the nitrogen-15/nitrogen-14 value for nitric acid is close to zero or is slightly enriched with nitrogen-15. A nitric acid standard prepared by EES-1 personnel has an average nitrogen-15/nitrogen-14 value of 1.0 per mil (Table 4.1-1). The treated effluent sampled at TA-50 contains elevated nitrate concentrations and low nitrogen-15/nitrogen-14 (Table 4.1-1) dominantly derived from nitric acid associated with the TA-55 waste stream.

Organic nitrogen derived from soils is enriched in nitrogen-15 and depleted in nitrogen-14. Accordingly, soils containing organic nitrogen are characterized by positive nitrogen-15/nitrogen-14 ratios that typically range from 3 to 7 per mil (Clark and Fritz 1997, 59168). Samples collected from R-9 (at 579 ft), R-12 (at $805 \mathrm{ft}$ ) and LA Spring have nitrogen-15/nitrogen-14 ratios consistent with those of nitric acid and perhaps soil organic nitrogen (Table 4.1-1).

Ammonium was detected in R-12 groundwater at a depth of $464 \mathrm{ft}$. Ammonium is the thermodynamically stable form of nitrogen under reducing conditions. The nitrogen-15/nitrogen-14 ratio for ammonium in this groundwater sample is 1.3 per mil, which implies a different source (abiological) of ammonium than that found in the samples at depths of 443 and $495 \mathrm{ft}$. The ammonium may be naturally derived from clay minerals through cation exchange or possibly from an industrial source such as laboratory cleaners containing ammonium. More work is required to understand the source(s) of ammonium found at depth in R-12.

\subsubsection{Aggregate 1 Conceptual Model Refinement}

The following bulleted items represent specific refinements to the hydrogeologic conceptual model resulting from extensive data collection in Aggregate 1 during FY98. Figures 4.1-7 and 4.1-8 depict conceptual model elements for upper Los Alamos Canyon and Pueblo Canyon. Specific refinements are as follows:

- The intermediate depth perched groundwater zones present on the eastern portion of the Laboratory are more numerous and have more complex flow paths than previously recognized. Both boreholes R-9 and R-12 encountered perched zones within the vadose zone, suggesting the presence of a large number of potential perching layers in all of the stratigraphic units penetrated. The saturated thicknesses of these zones were variable: some of the zones were thin (a few feet thick) while others showed saturated thicknesses greater than anticipated (more than 70 feet). Additionally, the field observations indicate many of the perched horizons are confined with hydraulic pressures of several tens of feet. The cumulated data suggests that delineating the direction or velocity of groundwater flow for all but the largest saturated zones may prove difficult.

- Based on geologic characterization of R-9 and R-12 cuttings and core, the geologic 3-D stratigraphic model for the northeast part of the Laboratory was modified to reassign tuffaceous rocks to the lower part of the Puye Formation that were previously assigned to top of the Santa Fe Group in PM-1. The top of the Santa Fe Group in the area around boreholes R-9 and R-12 consists of fractured basaltic lava flows rather than sedimentary rocks that are commonly found elsewhere. Groundwater movement through these basalts is expected to occur through fractures and along interflow contacts. 


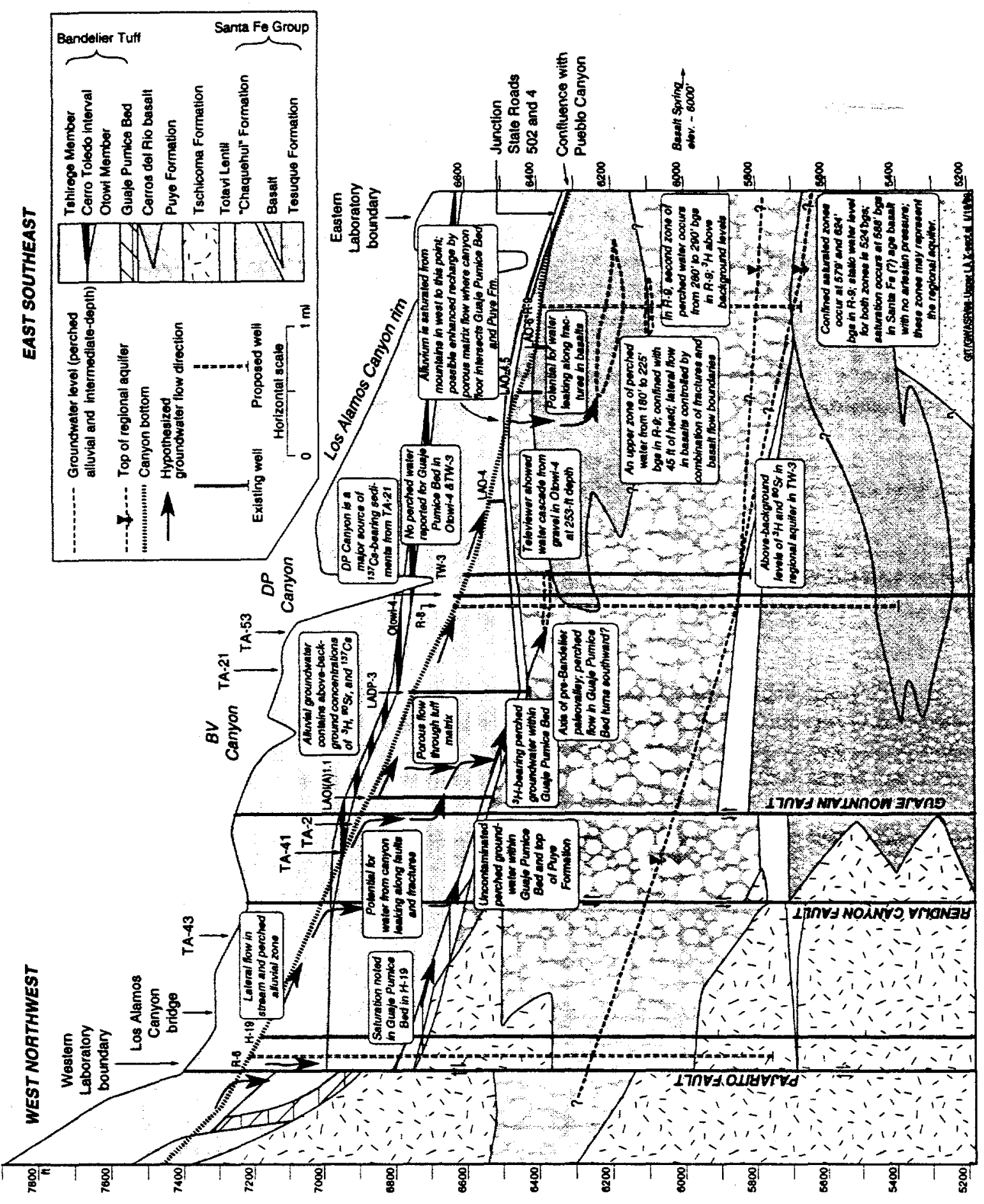

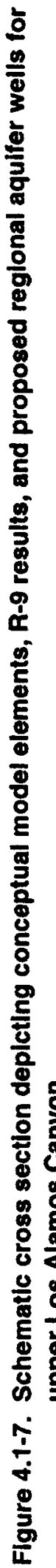




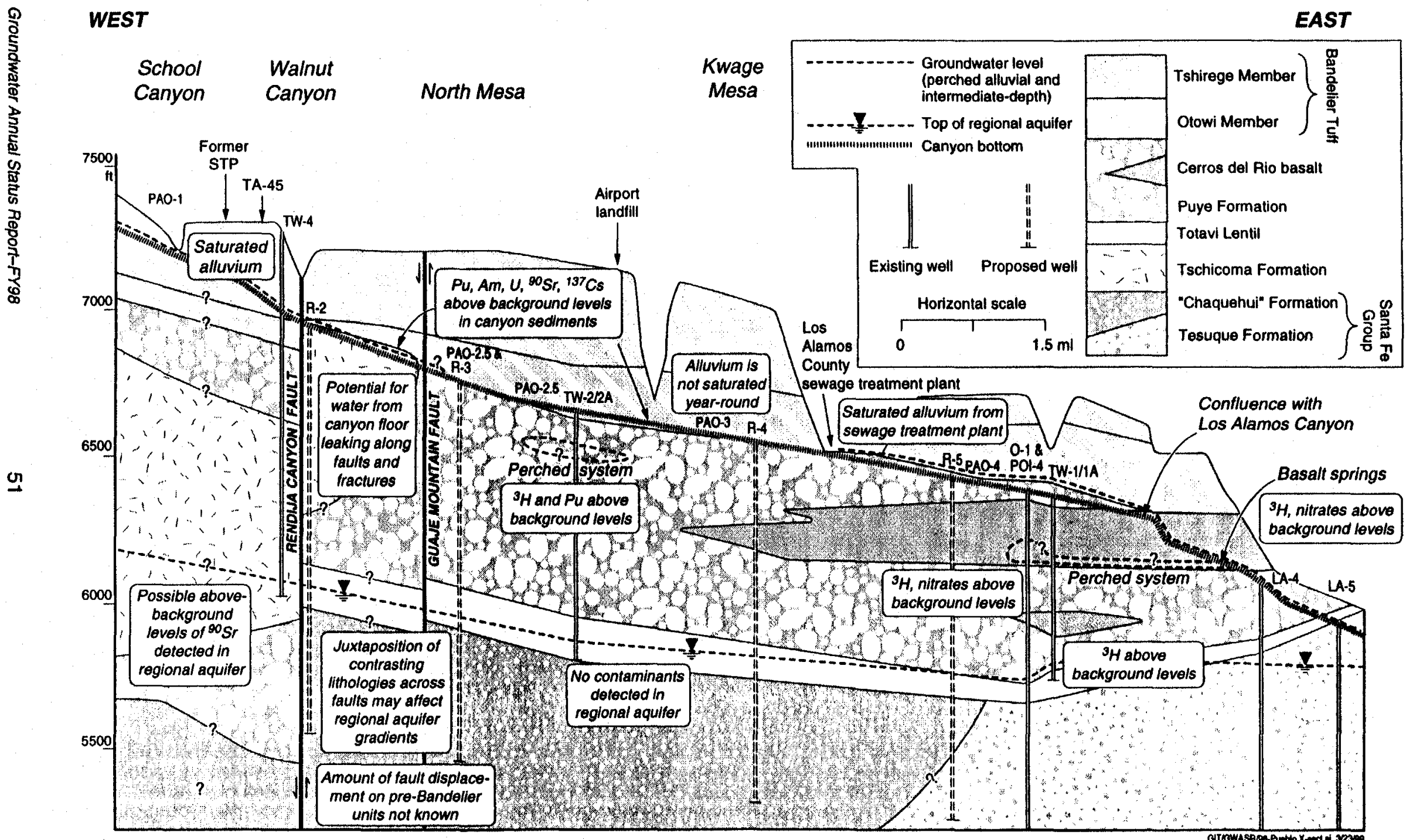

Figure 4.1-8. Schematic cross section depicting conceptual model elements and proposed regional aquifer wells for Pueblo Canyon. 
Based on its lithologic characteristics, the axial facies of the Puye Formation (Totavi Lenti) was expected to be a significant hydrostratigraphic unit that would be highly transmissive of groundwater. These axial Rio Grande deposits were expected to be penetrated at the base of the Puye Formation by boreholes R- 9 and R-12 based on lithologic logs from nearby water supply wells; however, they were not present. This suggests that axial Rio Grande deposits are not a single time-stratigraphic unit that was deposited over a widespread area prior to deposition of the Puye Formation as described by earlier studies. Furthermore, the occurrence of axial Rio Grande deposits high in the Puye Formation at borehole R-12 suggests that these deposits are time transgressive and may form discontinuous units of limited lateral extent throughout the Puye Formation.

- The largest perched groundwater systems encountered in borehole R-9 (Los Alamos Canyon) and R-12 (Sandia Canyon) occurred in basaltic rocks of the Cerros del Rio volcanic field. Similar occurrences of perched groundwater occur in Cerros del Rio basalt in lower Pueblo Canyon. However, the chemistry of groundwater in basalts beneath these three canyons suggests that these perched systems are not laterally connected.

In boreholes R-9 and R-12, the depth of the top of the regional water table is 28 to $99 \mathrm{ft}$ lower than what was predicted based on water levels in nearby water supply wells and water-level maps for the regional aquifer. The higher static water levels in nearby water supply wells are probably due to their long screen lengths, which create a composite hydraulic head for each well. The higher static water levels for the supply wells suggest that a higher hydraulic head occurs at deeper levels of the regional aquifer than those penetrated by R-12 and R-9 and that upward gradients may exist in the regional aquifer in this part of the Pajarito Plateau. If vertical gradients are verified with additional testing, the potential for Laboratory contaminants at the top of the regional aquifer to migrate deeper is much reduced. Upward hydraulic gradients are known to exist in supply wells east of R-12, near the Rio Grande (the old Los Alamos well field). Significant uncertainties exist, however, in our understanding of vertical gradients beneath the Laboratory. Preliminary results from the regional numerical flow modeling indicate minimal vertical gradients (i.e., predominantly horizontal flow) beneath most of the central portion of the Laboratory. The pumping of municipal supply wells may also locally alter the vertical gradients.

The tritium activity in the groundwater of the regional aquifer in boreholes R-9 and R-12 ranges from 14.43 to $46.9 \mathrm{pCil}$. These tritium activities suggest that the regional aquifer contains a component of surface water that is less than $\mathbf{5 0}$ years old. These findings support earlier test results obtained in old monitoring wells scattered across the Laboratory.

Elevated tritium activities and high concentrations of other solutes in perched groundwater in boreholes R-9 and R-12 suggest that these systems contain groundwater that has been impacted by Laboratory operations during the last 50 years. These data provides additional evidence for percolation of Laboratory effluents to significant depths (more than 500 feet) in the vadose zone.

While the tritium data are strong evidence that downward percolation has occurred, other chemical data from the various intermediate perched zones contributes to the growing recognition of complexity of the possible pathways from surface sources. Questions have been raised about possible sources of elevated levels of uranium, oxalate, and nitrate in some of the perched zones. Possible candidates could be Pueblo, Los Alamos, and Mortandad Canyons, but inconsistencies in the data leave numerous questions open at this time. 
A portion of the water moving through the vadose zone may be horizontally displaced for noteworthy distances from the source. Perched water in borehole R-12 may have been impacted by surface sources located on the order of one mile away, based on an initial interpretation of stable nitrogen isotopic analyses. The isotopic data indicates the water contains nitrogen originating from septic sources, most likely sewage effluents. The closest known sewage effluent streams are located approximately three quarters of a mile away in Pueblo Canyon and two miles away in Sandia Canyon.

In Pueblo Canyon, saturated conditions in alluvium upgradient of Bayo Canyon sewage treatment plant are ephemeral and discontinuous based on observed water levels in alluvial wells PAO-2.5 and PAO-3. Saturated conditions in alluvium are continuous and persistent downgradient of the Bayo Canyon Sewage treatment plant based on water level observations in alluvial wells PAO-4 and PAO-5N. The pattem of saturated conditions is complex in lower Pueblo Canyon where alluvium and the Puye Formation are in contact with saturation occurring to varying degrees in both units. The configuration of saturated alluvial sediments in lower Pueblo Canyon is controlled by paleo-terraces developed on the Puye Formation. The depth to the base of the alluvium and the depth to saturation increases to about $35 \mathrm{ft}$ towards the center of the canyon (north of the modern stream channel) based on the results of the PAO-5 transect.

\subsubsection{Aggregate 1 FY99 Planned Activities}

- $\quad$ Temporary well R-9 will be completed in late March or early April of FY99 following completion of DP borehole R-25 at TA-16. Following discussions between the GIT and the NMED, a decision was made to complete R-9 as a single completion well at the top of the regional aquifer. This completion strategy will allow the characterization of water quality at the top of the regional groundwater system at the eastern Laboratory boundary. An additional $60 \mathrm{ft}$ of borehole will be drilled during completion activities to make room for a 40-ft screen located at the top of the regional groundwater system and a 10-ft sump.

- $\quad$ Two alluvial wells, PAO-1 and PAO-2, will be installed in the western part of Pueblo Canyon. PAO-1 will be located west of the confluence and will provide background information. PAO-2 will be located east of the confluence between Pueblo Canyon and Acid Canyon and will provide alluvial water quality data downgradient of contaminant release sites in the headwaters of Acid Canyon.

- The GIT will examine the possibility of installing a west to east transect of three multi-port wells in the upper 500 to $700 \mathrm{ft}$ of the regional aquifer to collect information on the vertical distributions of hydraulic head across the Laboratory. R-12, R-5, R-15, and R-31 are considered candidates for the deep multi-port well in the eastem part of the Laboratory.

- Borehole R-12, located $1 \mathrm{~km}$ south of R-9, currently contains a temporary casing and will not be completed as a monitoring well in FY99 because of funding constraints in the ER Project. In FY99, the GIT will recommend whether to complete R-12 at its current depth of $874 \mathrm{ft}$ at the top of the regional aquifer or to deepen the borehole so that vertical hydraulic gradients can be investigated through installation of a multiport well completion.

\subsection{Aggregate 2}

Aggregate 2 is located in the east-central portion of the Laboratory and encompasses the technical areas where chemical and radioactive waste management are routine operations. The general boundaries of the aggregate are Pajarito Canyon on the south, Cañada del Buey to the north, TA-18 and TA-51 to the west, and the Laboratory boundary along state road NM 4 to the east (Figure 4.2-1). 


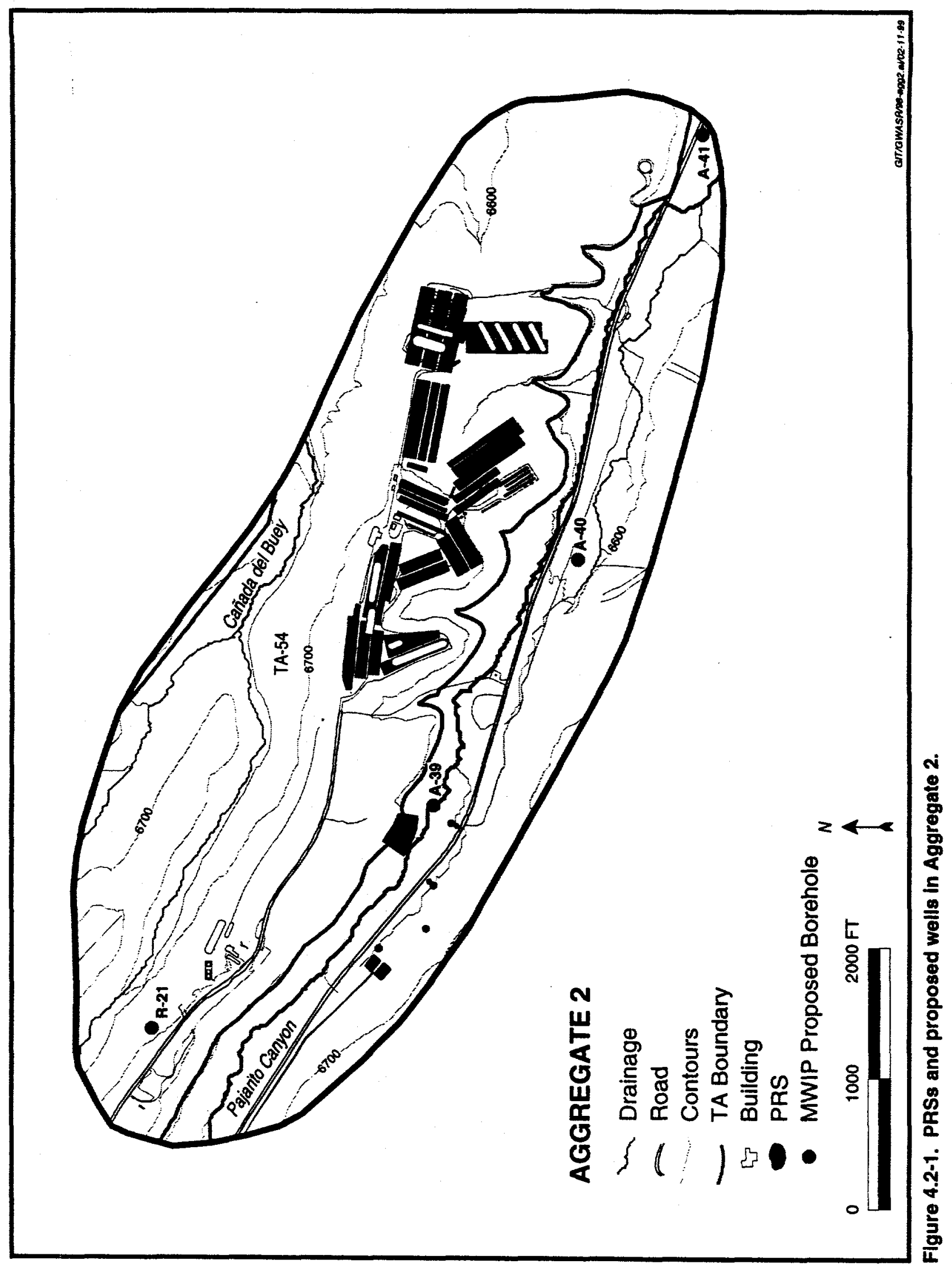




\subsubsection{Aggregate 2 FY98 Investigations}

\section{TA-18}

- Groundwater activities at TA-18 during FY98 included quarterly sampling of alluvial wells for investigating possible VOC contamination near a septic system. Eight quarters of data indicate no detections of VOCs. The tank will be removed as part of a voluntary corrective action (VCA) plan.

- Background alluvial well BG-4 was drilled in Threemile Canyon above TA-18. BG-4 was drilled to a depth of $25 \mathrm{ft}$ and alluvial groundwater was encountered at a depth of $2.5 \mathrm{ft}$. The alluvium was $6.25 \mathrm{ft}$ thick above weathered Bandelier Tuff.

- The water budget planned for Pajarito and Threemile Canyons was postponed. This may be taken up as part of the Work Plan for Pajarito Canyon.

- $\quad$ A Workplan for Pajarito Canyon was prepared during FY98. The plan was approved by DOE in August and sent to NMED in September for review. Development of the work plan was coordinated with TA-18 investigations.

\section{TA-54}

Most of the TA-54 investigations relate to the MDA G Performance Assessment (PA) Maintenance Program. The purpose of the PA Maintenance is three-fold: (1) ensure the continued applicability of the PA to current facility activities, (2) reduce uncertainties in the hydrological modeling and dose assessments in the PA, and (3) conduct performance monitoring of MDA G. Hydrological investigations conducted in the maintenance program address uncertainties related to liquid water infiltration and vapor phase movement. The water and vapor movement, in tum, might lead to radionuclide migration. Monitoring activities satisty PA maintenance requirements and have potential impacts on RCRA permit requirements. Most of these tasks are multi-year activities, and result are not available for all projects.

The current suite of PA Maintenance activities will continue for the next 2 to 4 years, up to the next revision of the PA. The 2 to 4 year timeframe is a timeframe set by DOE to address key items identified in their review of the PA. The maintenance items will probably continue through the lifetime of MDA G, especially the performance monitoring.

- Vegetative cover measurements were made at MDA G to assist in future surface water budget determinations. The vegetative cover project will need at least the remainder of this fiscal year to collect enough data to produce meaningful results.

- Water vapor flux from MDA G into the atmosphere was measured using Lidar (short for light detection and ranging) to quantify spatial variability in evapotranspiration and assist in future surface water budget determinations. Lidar operates by sending a pulsed laser beam into the atmosphere. Gases, aerosols, and particles in the atmosphere reflect the laser light; this return signal is collected by a telescope and focused onto a detector. Lidar measurements are anticipated to continue in FY99. The Lidar project will need at least the remainder of this fiscal year to collect enough data to produce meaningful results.

- The ER Project continued pore gas monitoring at TA-54, MDAs L and G. 
- Waste Management personnel monitored subsurface moisture using neutron probe measurements. Moisture monitoring holes include five vertical holes and two vertical access tubes in pits, which are monitored every other month. Eight additional holes are monitored annually. Three pits now have horizontal holes installed: two holes under pit 15, four holes under pit 38, and three holes under pit 39. These horizontal holes will be monitored in FY99.

The moisture monitoring data has identified subsurface intervals in several boreholes where moisture appears to be increasing (statistically significant). The magnitude of increase is not of immediate concem. The mechanism or reason for the increase is not clear in all locations. At one borehole, which is impacted by runoff from an adjacent asphalt pad, the moisture increase could be attributed to increased infiltration from runoff. The close proximity of the asphalt pad may also have an impact.

Pit moisture data appears fairly static. A moisture plug that was identified in one pit location (due to ponding) several years ago continues to dry out with time: that is, the maximum spike is decreasing and the vertical extent of the plug is increasing. This drying out is increasing the moisture content at depth slightly.

- Waste Management personnel measured subsurface VOC concentrations in four boreholes instrumented with FLUTe (SEAMist) positive pressure sampling membranes. VOC monitoring in Area $\mathrm{G}$ boreholes has identified trichloroethane (TCA) and trichloroethylene (TCE) in the subsurface. The concentrations appear to be greatest near the east end of the mesa (near the oldest pits). A better idea of the nature and extent of subsurface VOCs will develop as additional boreholes throughout the area are instrumented.

- $\quad$ Air pressure data collection continued in order to evaluate how barometric pressure moves through the mesa. This study is directed at evaluating how tritium and VOC migration occurs within the mesa at MDA G. In situ measurement of $\mathrm{CO}_{2}$ also was made within the mesa. Air pressure measurements are still in process, but preliminary data show that atmospheric pressure damps with depth, and that damping is greater below the highly fractured Tshirege Unit 2.

- Measurements continued on the Pilot Extraction Study Plan at MDA L. The purpose is to evaluate the potential for long-term passive vapor extraction within the mesa to remove the VOC plume.

\subsubsection{Aggregate 2 Conceptual Model Refinement}

Conceptual model elements are depicted on Figure 4.2-2.

\section{TA-18}

Activities at TA-18 resulted in no conceptual model refinements.

\section{TA-54}

Activities at TA-54 resulted in no conceptual model refinements. 


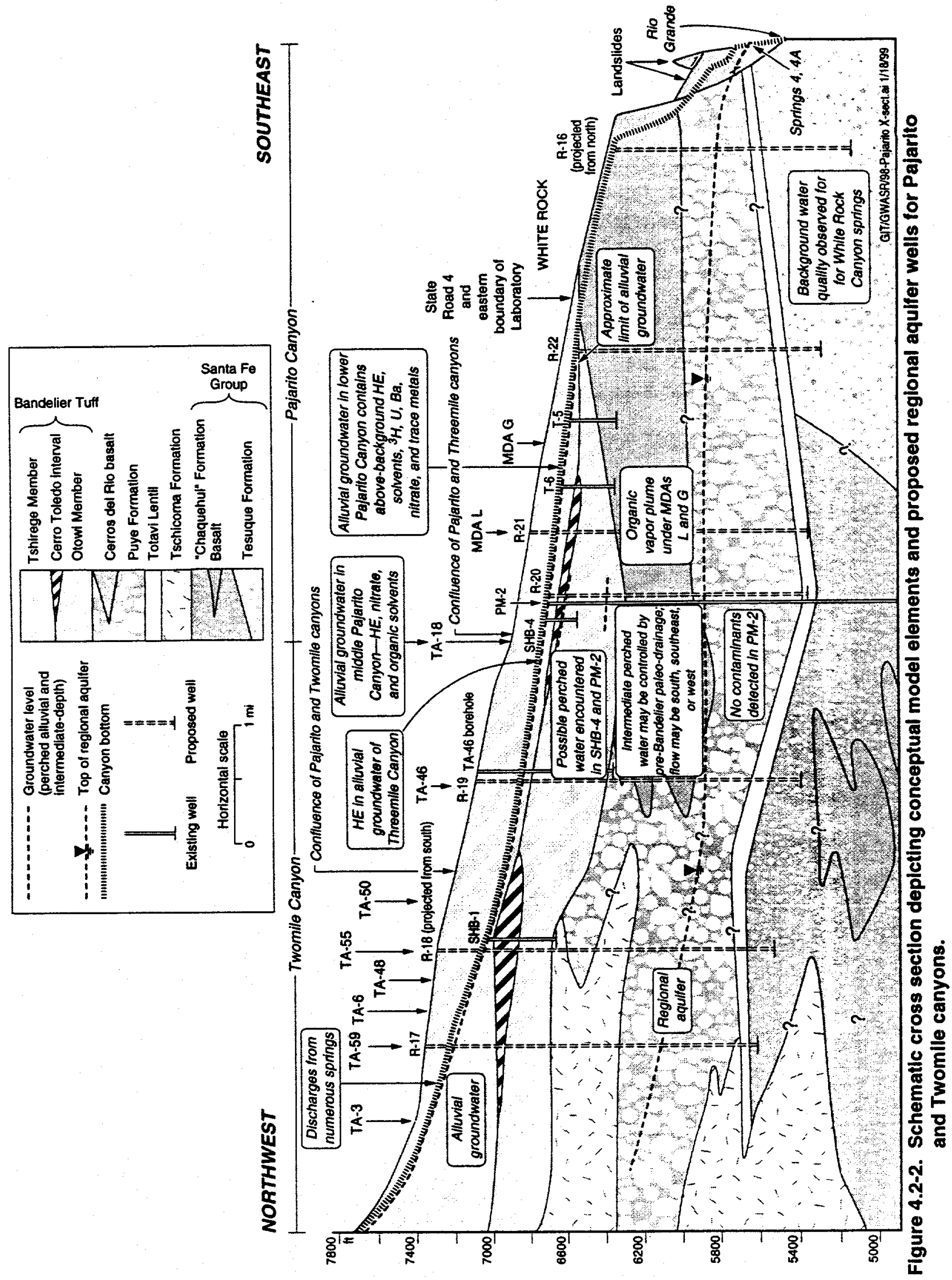




\subsubsection{Aggregate 2 FYgg Planned Activities}

TA-18

- The septic tank will be removed as part of a VCA plan.

\section{TA-54}

- Pore gas monitoring and neutron probe measurements will continue. Some boreholes will be instrumented for moisture monitoring, and for vapor and moisture sample collection. Horizontal holes under pits will be reentered and evaluated.

- Shallow isotope and chemical profiles (stable isotopes and chloride) will be measured to determine patterns of infiltration.

- $\quad$ Further vegetative cover measurements will be made.

- Lidar water vapor flux measurements will continue.

- In order to evaluate effects of asphalt pads on moisture buildup and infiltration, horizontal trenches with neutron access will be installed at a depth of about 1 meter prior to placing an asphalt pad over pit 7 . The trenches will include ports for VOC sampling. Thermocouples will also be installed for temperature measurements.

- $\quad$ Air pressure monitoring will continue.

- Surface gas/vapor flux processes will be investigated utilizing natural tracers $\left(\mathrm{CO}_{2}\right.$, VOCs).

- Modeling and other work for the Pilot Extraction Study Plan will be finalized. A design for a passive vapor extraction system will be prepared. ER cut this task for FY99 due to budget shortfalls; it will be baselined for next year.

\subsection{Aggregate 3}

Aggregate 3 is located in the south central portion of the Laboratory and consists of TA-49 on Frijoles Mesa. Aggregate 3 is bounded by Water Canyon on the north, state road NM 4 on the south, TA-39 is the east boundary, and TA-16 is on the west (Figure 4.3-1).

\subsubsection{Aggregate 3 FY98 Investigations}

- $\quad$ MDA AB, Area 2 has a large subsurface inventory of plutonium as well as other metals. An asphalt pad was placed over Area 2 to improve isolation of surface contamination. The pad caused near-surface moisture contents to rise to saturated or near saturated conditions. To address this problem and dry the site out, a stabilization plan was submitted to NMED for implementing the asphalt pad removal interim measure and best management practices (BMPs). A moisture-monitoring plan for Area 2 was also submitted to NMED for implementation in FY99.

- The asphalt pad at MDA AB, Area 2 was completely removed as described in the stabilization plan. Removal of the pad should eventually improve evapotranspiration conditions at the site. A radiological survey was conducted on the exposed materials, but no material was removed. $A$ clean cover of crushed tuff was applied along with topsoil and gravel mulch. A surface water diversion trench was installed upslope from Area 2 and the site was regraded as part of BMP activities. 


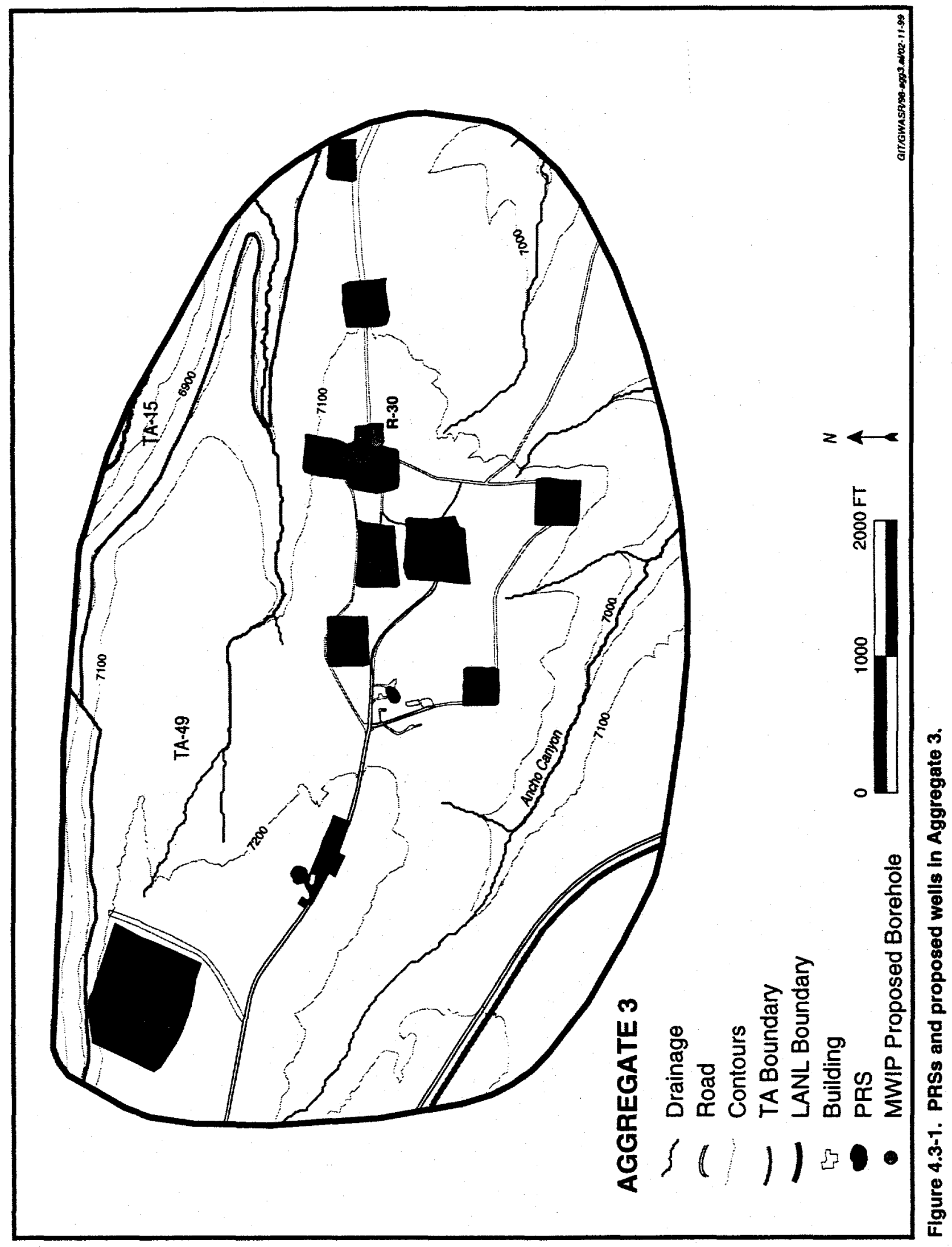


Corehole 2 was logged to $500 \mathrm{ft}$ with a neutron probe for volumetric moisture determination. Other holes in the vicinity of Area 2 were also logged. Preliminary results indicate that the Corehole 2 moisture profile is generally wetter at depth (e.g., $35 \%$ at $180 \mathrm{ft}$ ) than is typical for profiles measured in boreholes away from the asphalt pad. Corehole 2 has had standing water in the past, but it is not clear whether the standing water and elevated moisture content are artifacts of the borehole construction or representative of conditions under the asphalt pad. The hole was permanently plugged after the profile was taken.

\subsubsection{Aggregate 3 Conceptual Model Refinements}

The elevated near-surface moisture content of the tuff associated with the asphalt pad at MDA AB supports the Hydrogeologic Conceptual Model for Mesas that disturbed mesa-top conditions can increase the downward flux of water. Figure 4.3-2 graphically depicts elements of the Hydrogeologic Conceptual Model near TA-49 and MDA AB.

\subsubsection{Aggregate 3 FY99 Planned Activities}

- The objective of FY99 activities is to bound vertical contaminant migration potential. To achieve this objective, a vertical hole will be drilled through an unused shaft and characterized for hydrogeologic properties. In addition, an angled directional borehole will be drilled undemeath Area 2 to examine the current vertical extent of contamination. This hole will also be used for various monitoring activities. Finally, an interflow monitoring trench will be installed to assess the impact that lateral flow might have on contaminant mobility at Area 2.

\subsection{Aggregate 4}

Aggregate 4 includes TA-33, TA-39, Ancho Canyon, Indio Canyon, and Chaquehui Canyon which are located in the southwest part of the Laboratory (Figure 4.4-1). Laboratory facilities and operations occurred on the mesa top at TA-33 and within a canyon setting at TA-39. Ancho and Chaquehui canyons are the principal watershed systems in this aggregate.

\subsubsection{Aggregate 4 FY98 Investigations}

Two rounds of water level measurements were conducted in 5 monitoring wells completed in canyon bottom alluvium near MDA Y located in the northem branch of Ancho Canyon at TA-39. The first round was completed on December 17, 1997 and the second round was completed on June 30, 1998. During the December round of measurements all of the wells were dry. During the June round all of the wells were dry except one (well DM-6) that had approximately $0.15 \mathrm{ft}$ of water.

Water samples from Ancho Spring were collected November 11, 1997 and September 29, 1998 and analyzed for HE residual compounds, amongst other constituents. No HE compounds were detected.

\subsubsection{Aggregate 4 Conceptual Model Refinement}

Conceptual model elements for Aggregate 4 are depicted on Figure 4.4-2. Some refinements to the conceptual model stem from work in 1998. The water level measurements in FY98 demonstrate the general absence of shallow groundwater in the northem branch of Ancho Canyon. Thin zones of saturation apparently develop in the alluvium for limited periods of time, likely after periods of heavy local precipitation or snowmelt. Stream gaging in the main branch of Ancho Canyon near SR-4 (approximately one mile downstream of the TA-39 wells) shows streamflow only a few days per year. The absence of any sustained streamflow or effluent discharges indicates the alluvium throughout Aggregate 4 probably is dry but for a few days or weeks per year. Earlier RFI investigations in this area by the ER Project had raised questions about the presence of a shallow groundwater zone in the canyon floor. 


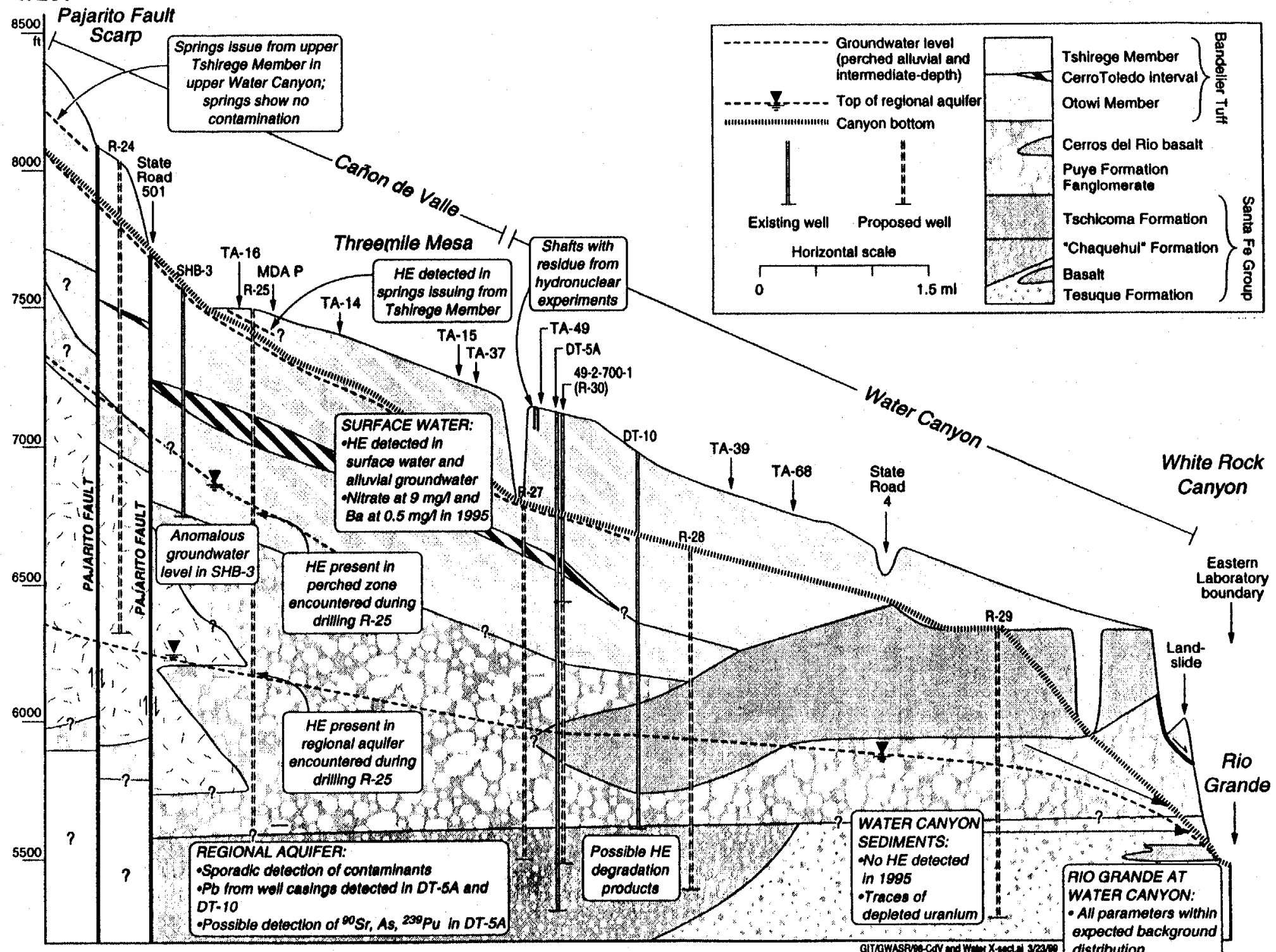

Figure 4.3-2. Schematlc cross section depleting conceptual model elements and proposed regional aquifer wells for Cañon de Valle and Water Canyon. 


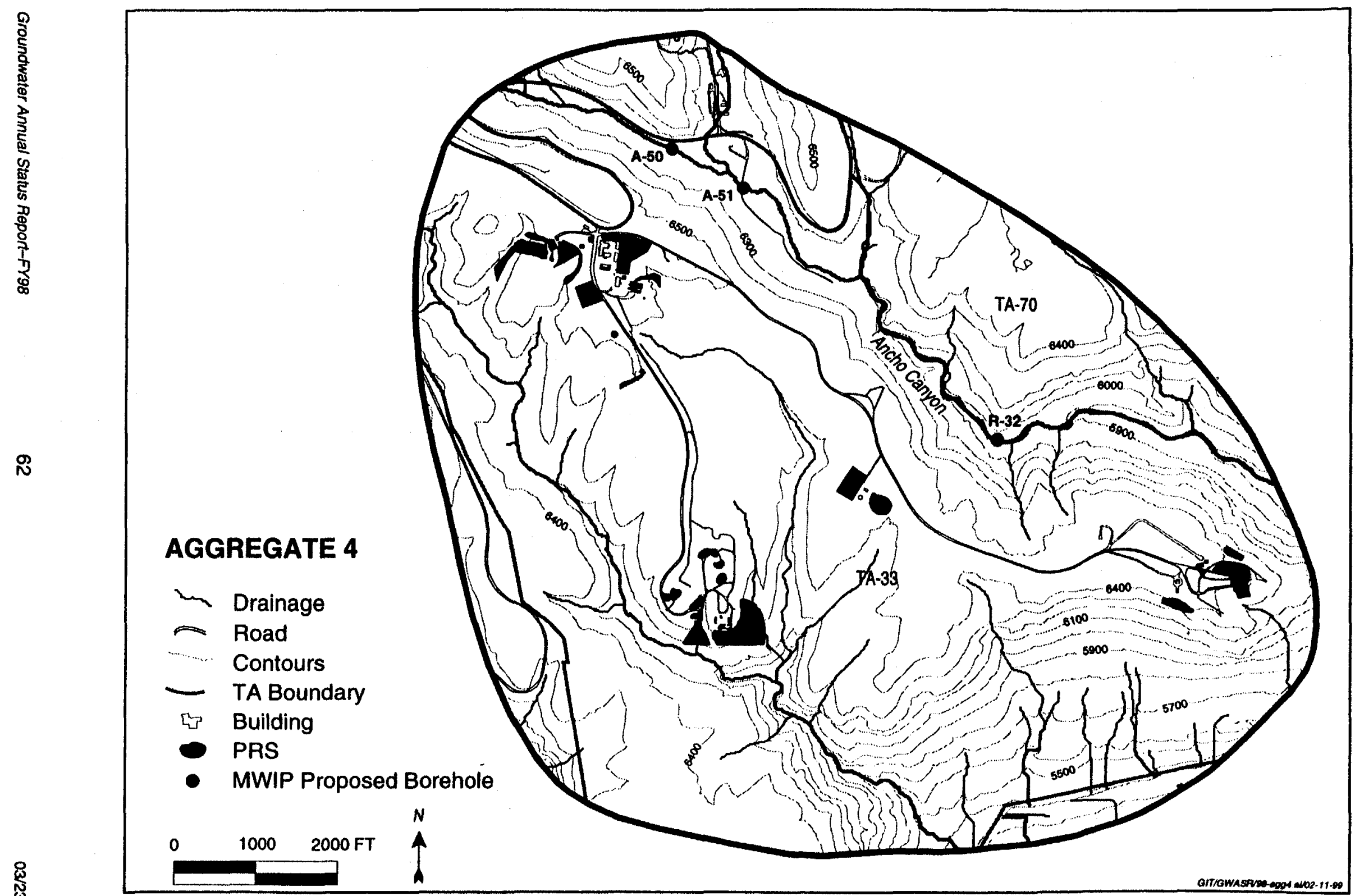

Figure 4.4-1. PRSs and proposed wells in Aggregate 4. 


\section{WEST}

$$
{ }_{200}^{T A-49}
$$

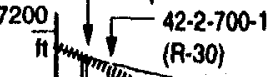

Southern end of

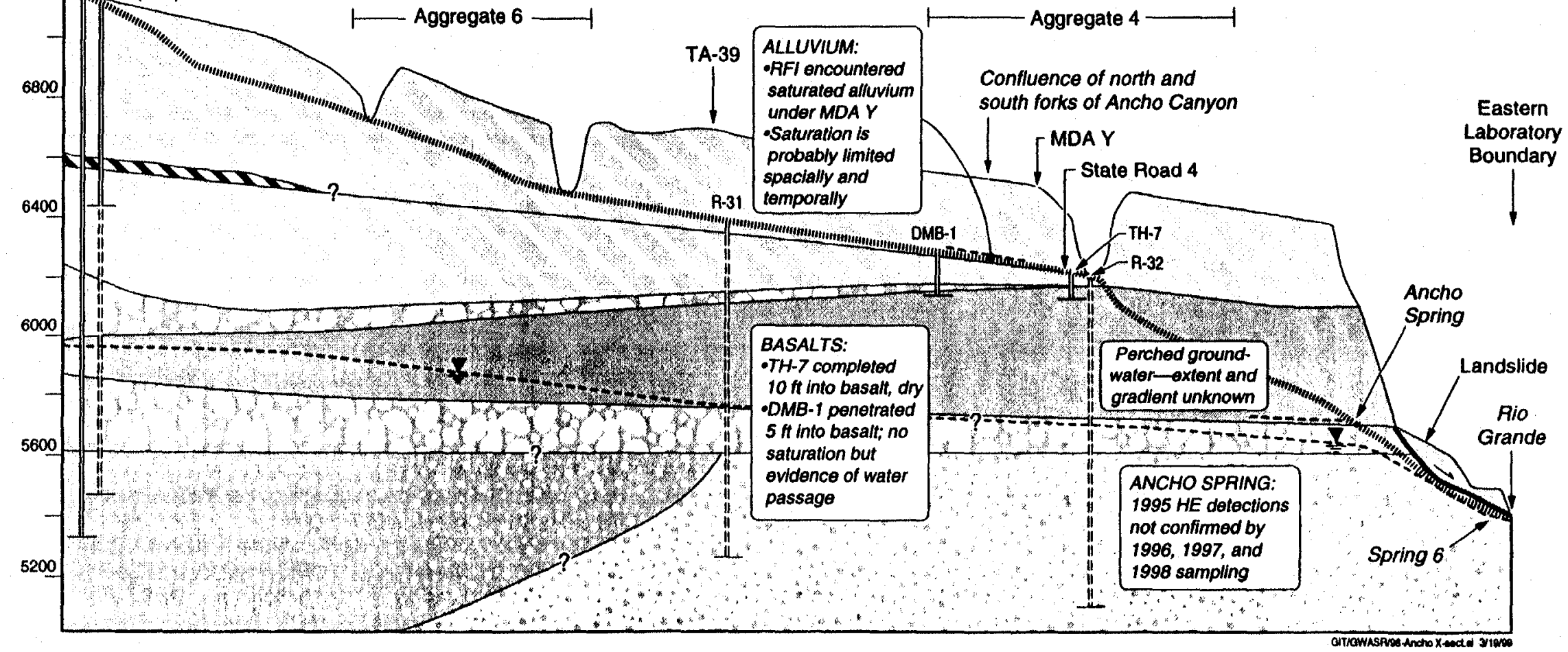

- Groundwater level (perched alluvial and intermediate-depth) _.... T. . ... Top of reglonal aquifer

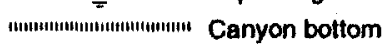

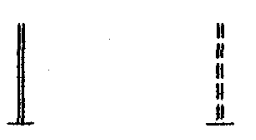

Existing well Proposed well $\overbrace{0}^{\text {Horizontal scale }}$

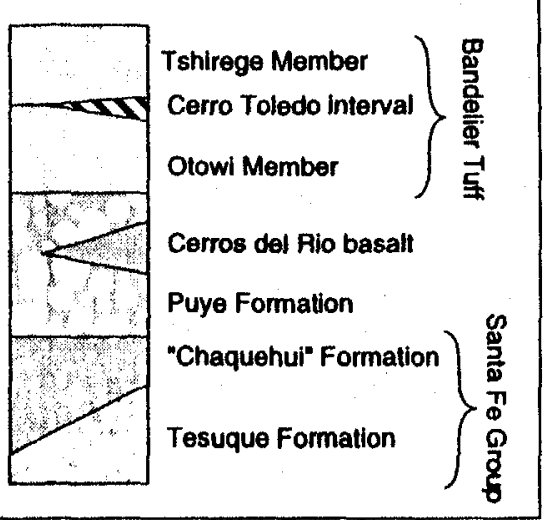

Aggregate $4 \longrightarrow$

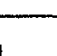

EAST

๕

Figure 4.4-2. Schematic cross section depicting conceptual model elements and proposed regional aquifer wells for Ancho Canyon. 
Analyses in 1996, 1997, and 1998 have failed to confirm earlier detections of HE compounds in Ancho Spring. in 1995, three HE compounds were detected in Environmental Surveillance samples of the spring: RDX (23 $\mu \mathrm{g} / \mathrm{L})$; octahydro-1,3,5,7-tetranitro-1,3,5,7-tetrazine (HMX) (4.9 $\mu \mathrm{g} / \mathrm{L})$; and 2-4dinitrotoluene $(2-4-D N T)(0.18 \mu \mathrm{g} / \mathrm{L})$. The lack of confirmation indicates the HE contamination is limited and variable over time, or the earlier results were due to either sampling or analytical error.

\subsubsection{Aggregate 4 FY99 Planned Activities}

The drilling of DP-funded borehole R-31 in Ancho Canyon will commence in FY99. It will provide site-wide characterization information in an area of the Laboratory that the subsurface is largely unexplored. Among other items, R-31 will provide key information about the presence of a possible perched groundwater system (that ultimately feeds water to Ancho Spring) and its associated water quality.

\subsection{Aggregate 5}

Aggregate 5 is bounded on the south by Water Canyon and on the north by the boundary of TA-9. Cañon de Valle is a tributary to Water Canyon; they join at the east end of TA-16 and form the eastern boundary of Aggregate 5. The western boundary of Aggregate 5 is formed by state road NM 501 (Figure 4.5-1).

\subsubsection{Aggregate 5 FY98 Investigations}

- $\quad$ An RFI report (LANL 1998a) and Corrective Measures Study Plan (LANL 1998b) for the 260 outfall were submitted to NMED. Findings are briefly discussed in Section 4.5 .2 below.

- The bromide tracer test is continuing. Results so far support a hydrologic connection between the 260 outfall and SWSC spring. There may also be a connection to Burning Ground Spring, but the data are not as clear as for SWSC spring.

- Quarterly sampling for contaminants and major cations and anions in the springs and alluvial aquifer, and water level measurements in the Cañon de Valle wells were performed. The sampling indicates substantial and temporal variation in contaminant chemistry (HE and barium) in Cañon de Valle, and temporal variation in the springs.

- Water level measurements in Cañon de Valle show seasonal changes, and the data will be used as part of upcoming determinations of water balance. Monitoring of spring flow shows a complicated response to precipitation and snowmelt events. For some monsoon events, initial response of spring flow occurs in less than two hours, while other impacts on spring flow occur on much longer time scales. The varying characteristic times on spring flow changes from monsoon events indicate multiple flowpaths are probably impacting the springs. 


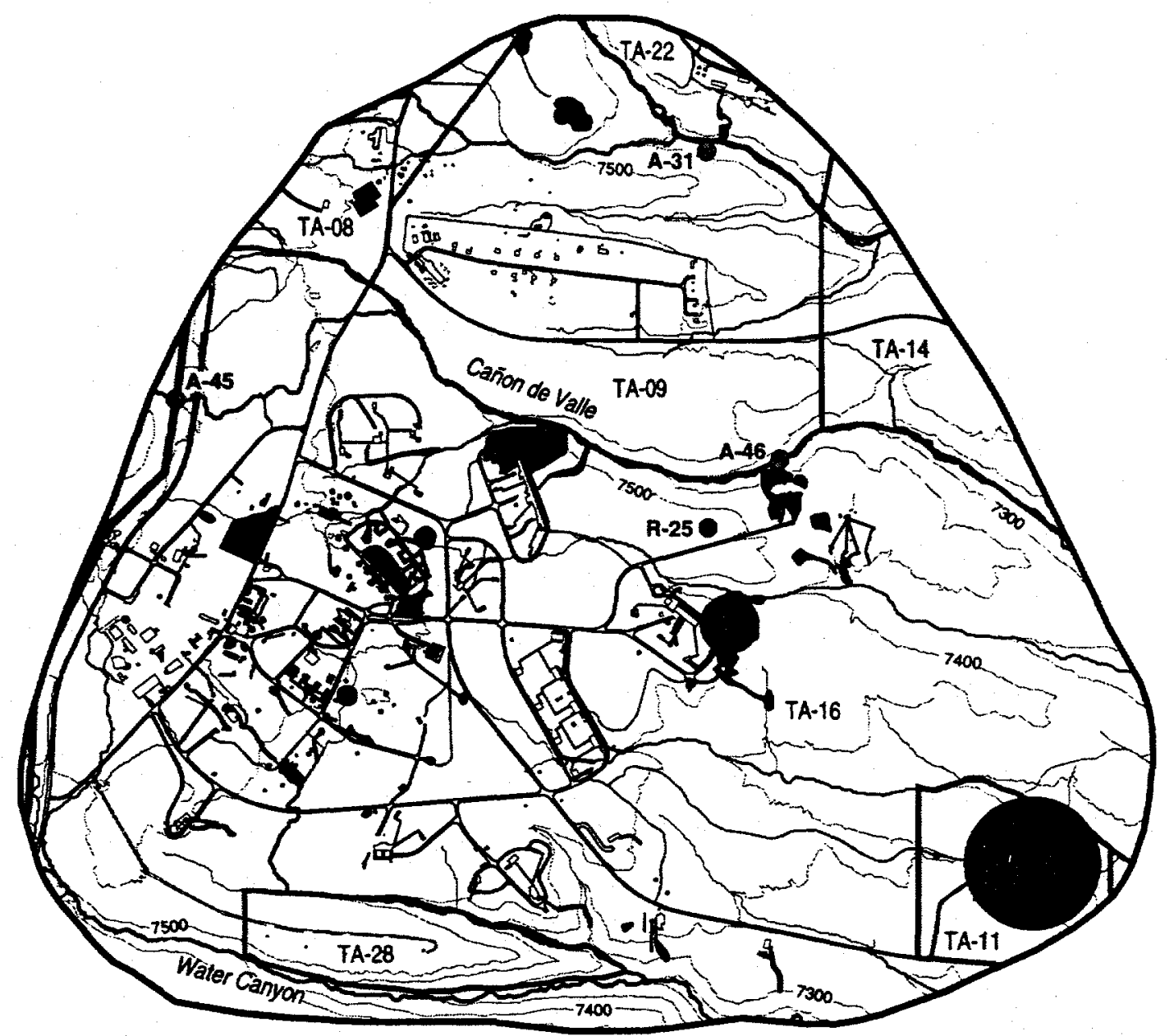

AGGREGATE 5

$$
\begin{array}{ll} 
& \text { Drainage } \\
\text { Road } \\
& \text { Contours } \\
& \text { TA Boundary } \\
& \text { LANL Boundary } \\
& \text { Building } \\
\quad \text { PRS } \\
\text { MWIP Proposed Borehole }
\end{array}
$$

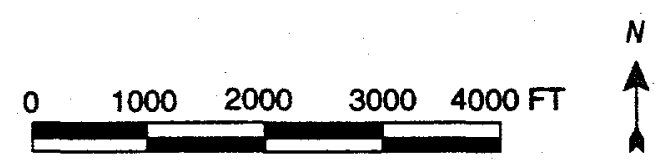

Figure 4.5-1. PRSs and proposed wells in Aggregate 5. 
- Borehole R-25 is located in the Laboratory's TA-16 on the south rim of Cañon de Valle. TA-16 operations include HE research, development, testing, and manufacturing activities. R-25 is designed to provide information about hydrologic and geologic conditions beneath the relatively unstudied southwest part of the Laboratory and to characterize potential Laboratory impacts on groundwater in the area. R-25 was drilled to a depth of $1942 \mathrm{ft}$ and encountered two major zones of saturation. The upper zone of saturation was encountered from depths of $747 \mathrm{ft}$ to $1132 \mathrm{ft}$ in the lower part of the Otowi Member of the Bandelier Tuff and the upper part of the Puye Formation (Figure 4.5-2). From $1132 \mathrm{ft}$ to $1286 \mathrm{ft}$, the borehole penetrated alternating zones of wet and dry rock in the Puye Formation. It can not yet be determined whether the 385-ft-thick upper groundwater zone is perched or part of the regional aquifer. Continuous saturation was again encountered from depths of $1286 \mathrm{ft}$ to the total depth of $1942 \mathrm{ft}$ and is almost certainly associated with the regional aquifer. High explosives and chemicals associated with their breakdown were present throughout the upper zone of saturation and in all but the lower $200 \mathrm{ft}$ of the regional aquifer penetrated by the borehole. High explosive contaminants found include RDX; HMX; TNT; 4-amino-2,6 DNT (4-A-DNT); 2-amino-4,6 DNT (2-A-DNT); and 1,3,5-trinitrobenzene. Concentrations of RDX and TNT exceed EPA Health Advisory Guidance Values for drinking water (Figure 4.5-2). As a result of the findings at borehole R-25, the nearest six water supply production wells on Laboratory property were tested for the presence of HE. Samples from these wells contained no HE or HE degradation products.

- Quarterly sampling for contaminants and major cations and anions in the springs and alluvial aquifer, and water level measurements in the Cañon de Valle wells were performed.

- Geochemical modeling results using PHREEQC suggesting barite supersaturation in Cañon de Valle springs and alluvial waters were confirmed by the presence of barite $\left(\mathrm{BaSO}_{4}\right)$ in sediment samples. In addition, the PHREEQC results and sediment analyses suggest that witherite $\left(\mathrm{BaCO}_{3}\right)$ precipitation and dissolution may control some of the temporal and spatial variability in dissolved barium concentrations in Cañon de Valle alluvial waters.

- Four boreholes were drilled to $100-200 \mathrm{ft}$ depths on the TA-16 mesa to look for contaminants and the saturated systems that feed the springs (see Figure 4.5-3). Transient saturated zones were encountered in borehole 2669 (near the 90 s line pond) and 2665 (near Martin spring). No permanent saturation was encountered. These boreholes were completed as monitoring wells. The other two dry holes were cased with PVC without screens to be used as neutron probe moisture holes.

\subsubsection{Aggregate 5 Conceptual Model Refinements}

Conceptual model elements for Aggregate 5 are depicted on Figure 4.3-2. Conceptual model elements specific to TA-16 are depicted on Figure 4.5-4.

- Data collection continues to support the conceptual model described in the RFI report. Namely, that thin perennial saturated ribbons in the mesa feed the three springs. In addition, transient saturated zones may also recharge the springs and transport contaminants. The importance of transient saturation in the tuff and soil zone is indicated by the bromide tracer results, the presence of transient saturation in four boreholes (the two mentioned above and two of the holes in the 260 outfall drainage) and by the presence of interflow at the new burn pad. The disappearance of the Cañon de Valle alluvial groundwater downstream from MDA P suggests that this groundwater may recharge a deeper groundwater system. This is consistent with the observation of HE in the Otowi-Puye saturated zone in borehole R-25. 


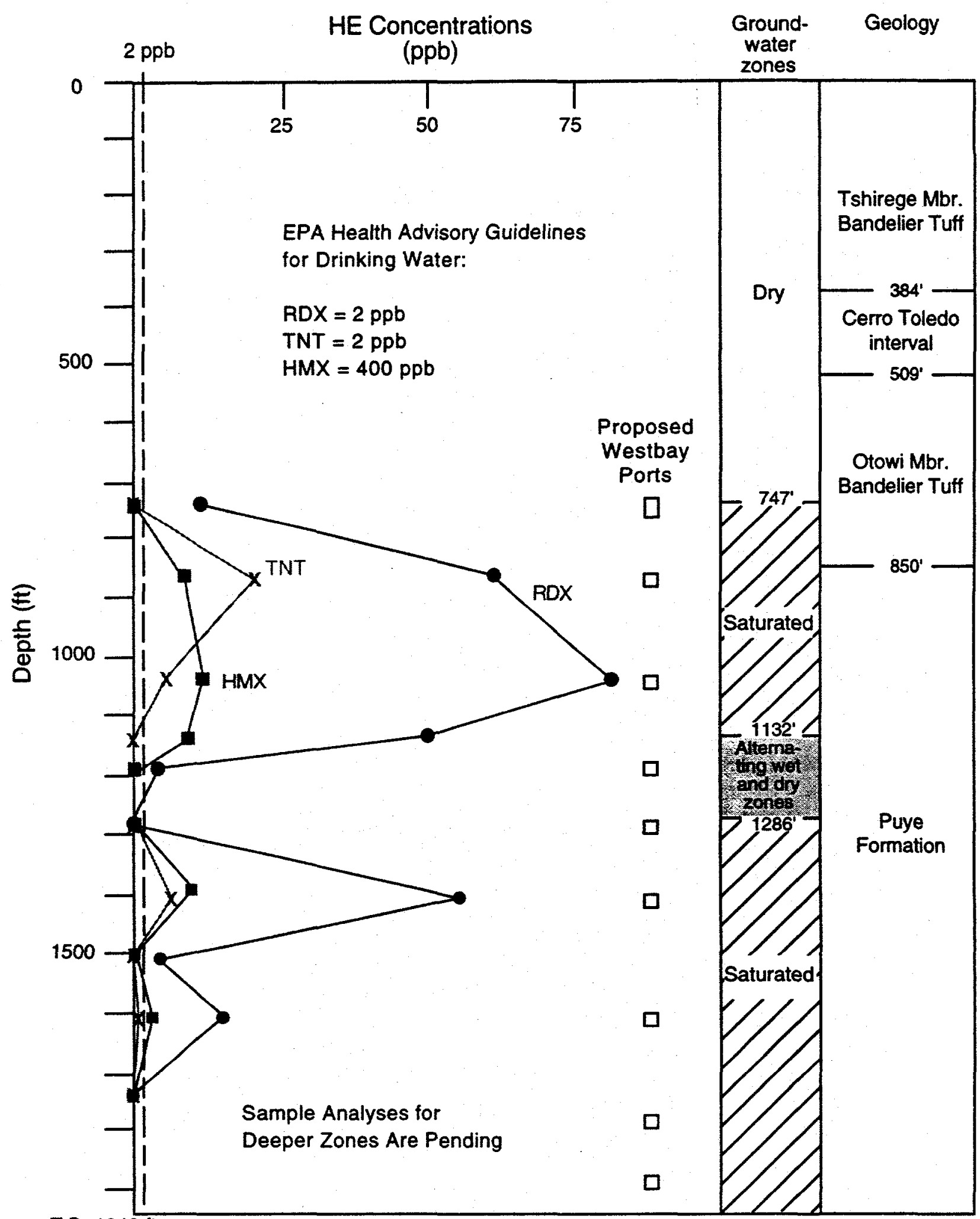

T.D. $1940 \mathrm{ft}$

Figure 4.5-2. Plot showing geologic units, groundwater zones, proposed monitoring zones and distribution of key HE constituents in borehole R-25. 


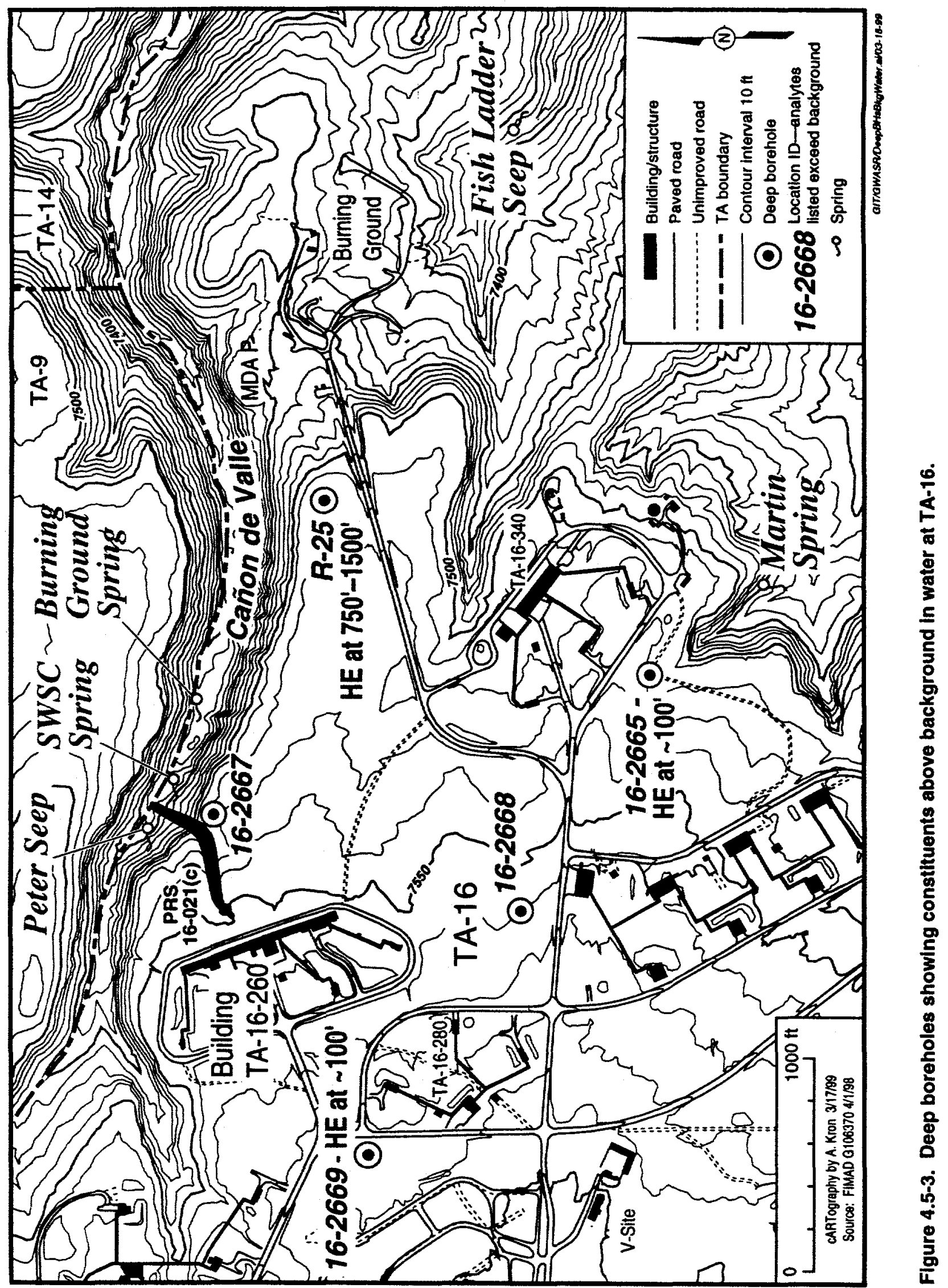




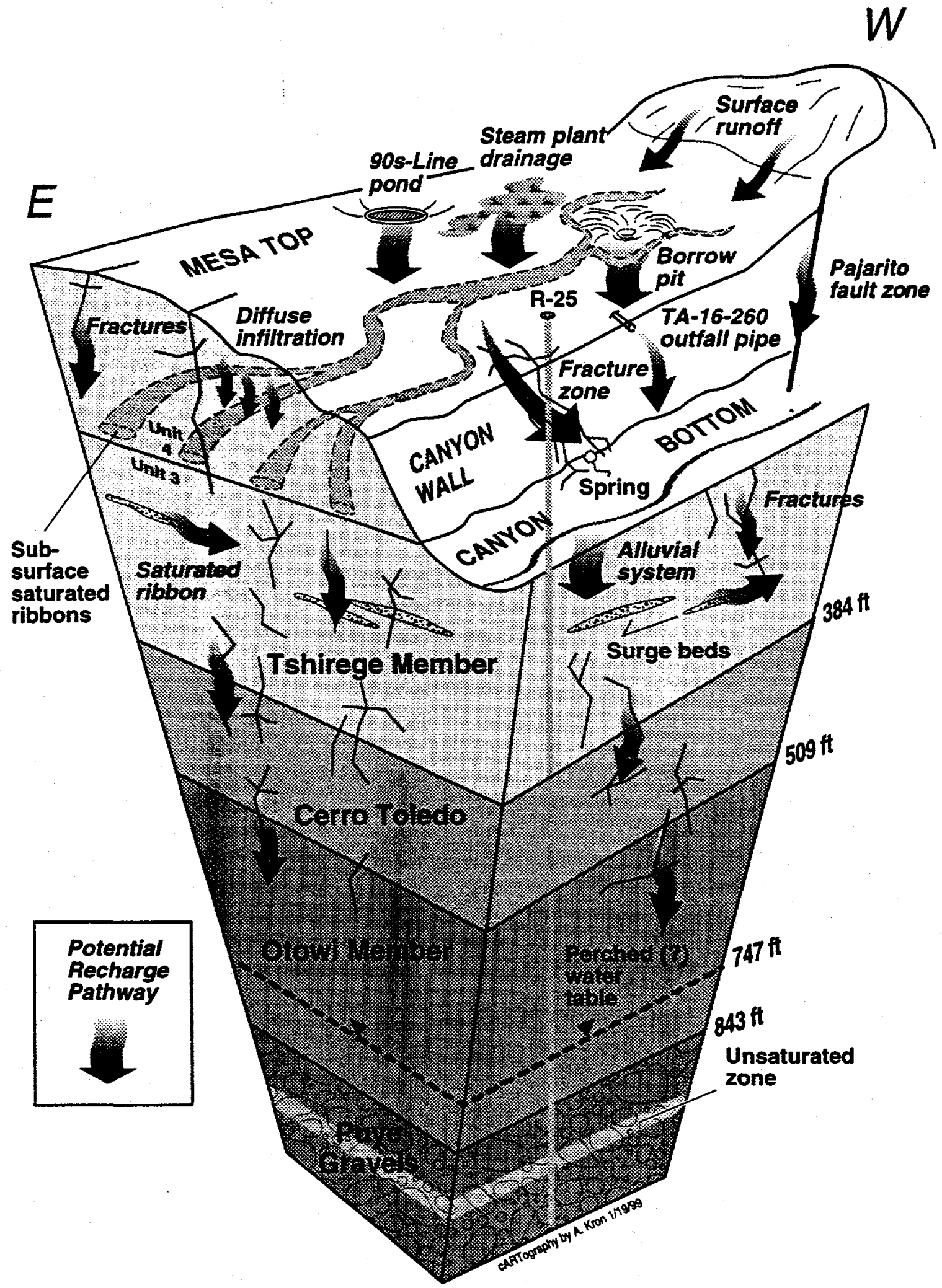

GITGWASACOnCthetrollodwT-16.003-18.99

Figure 4.5-4. Conceptual model elements at TA-16. 
Differences in the geochemistry and flow rate data between Martin and the Cañon de Valle springs suggest there may be an additional contaminant source (other than the 260 outfall) that feeds the Martin spring system. This source (or sources) has not been identified. In addition, the presence of barium and $\mathrm{HE}$ in the alluvial groundwater up-canyon from the 260 drainage suggest that additional contaminant sources may exist upstream from 260 . Possible candidates include MDA $R$ and the former silver outfall.

- Examination of detailed hydrographs for the springs at TA-16 provides insights into recharge at the springs, and hence into the subsurface hydrogeologic conceptual model for the near-surface western portion of the Laboratory. In addition, tracer studies at TA-16 indicate relatively direct connections of effluent sources with pathways to these springs. The data suggest that groundwater flow in this area is structurally controlled by surge beds and/or fractured intervals (LANL 1998a; LANL 1998b). Spring discharge and groundwater flow at shallower depths (less than $200 \mathrm{ft}$ ) evidently occurs as a result of highly channelized flow along discrete zones rather than as discharge from a larger porous media volume. Groundwater flow through fractures has long been recognized at the Water Canyon Gallery, located west of the Laboratory along the flank of the Sierra de los Valles. These analyses suggest the phenomenon extends further east beyond the Pajarito Fault Zone, onto the west side of the Laboratory. Contaminant transport through these systems thus may be rapid and seasonally variable.

- Detailed review of existing data raises the question of whether springs high on the flanks of the Sierra de los Valles may be fed largely or partially by an old source of groundwater as opposed to the presumption that they are sustained by contemporary precipitation.

The principal source of HE in the deep groundwater zones at borehole R-25 is believed to be the 260 outfall. The HE probably infiltrated along vertical pathways at the ponded area on the floor of the drainage fed by the 260 outfall as well as by a line source of recharge in the 260 drainage and along Canyon de Valle downstream of the outfall. Water level measurements taken during drilling of R-25 are consistent with downward vertical gradients in deep groundwater systems in this part of the Laboratory. The presence of HE in groundwater at R-25 indicates that deep groundwater is connected to the surface by relatively rapid groundwater pathways. The presence of the alternating saturated and nonsaturated rocks from 1132 to $1286 \mathrm{ft}$ suggests that the upper saturated zone is perched and that the lower zone of saturation represents the upper part of the regional aquifer. The upper zone of saturation at R-25 is probably the same as the groundwater zone encountered in SHB-3, located about $2 \mathrm{~km}$ to the southwest, suggesting an laterally extensive perched zone may occur throughout this part of the Laboratory.

The presence of barite and witherite in Cañon de Valle indicates that the residence time of barium in the canyon may be longer than for HE. Barium sorption is larger than HE, which will also increase residence times. The transport of barium minerals as sediment will also affect the residence time of barium in the canyon. In addition, the apparent dissolution/precipitation characteristics of witherite may play a role in temporal changes in dissolved barium concentrations.

The mesa conceptual model described in the Hydrologic Workplan suggests that mesa hydrology in the western part of the laboratory may be different than the better-characterized eastern portion. The results from Aggregate 5 indicate that the western mesas do have a different hydrologic character, one that is generally wetter and more heterogeneous. 


\subsubsection{Aggregate 5 FY99 Planned Activities}

- Borehole R-25 will be completed as a multi-port well with nine sampling ports. Locations of the proposed sampling ports are shown in Figure 4.5-5.

- A data collection effort in Cañon de Valle will be implemented to evaluate water and contaminant mass balance. This activity will provide information on contaminant inventory, help to define possible remediation options, and may explain the presence of HE that was found in R-25 early in FY99.

- A stable isotope $\left(\delta^{18} \mathrm{O}, \delta \mathrm{D}\right)$ tracer study will examine residence times of spring waters.

- A nitrogen isotope $\left(\delta^{15} \mathrm{~N}\right)$ sampling program will examine nitrogen sources in the springs and Cañon de Valle, and may provide information on biodegradation.

- Additional investigation of Martin Canyon hydrology will include drilling of at least one alluvial well.

- Finally, an interim measure will be implemented to remove highly contaminated material around the 260 outfall drainage. As part of the implementation plan, soils and tuff will be monitored for the bromide tracer. This will provide useful information for interpreting tracer behavior at TA-16.

\subsection{Aggregate 6}

Aggregate 6 is located in the south-central portion of the Laboratory and encompasses the technical areas where testing with HE and open detonation/open burning are part of routine operations. The general boundaries of the aggregate are Water Canyon on the south, Potrillo Canyon on the north, the Rio Grande to the east, and the Laboratory boundary along the Sierra de los Valles to the west (Figure 4.5-5).

\subsubsection{Aggregate 6 FY98 Investigations}

No studies were planned for or conducted in TA-15, TA-36 or TA-39 during FY98. However, numerous investigations were carried out at TA-16, in conjunction with the Phase II RFI study for the 260 Outfall (Anonymous, 1998). Activities included soil borings in the outfall and drainage areas, installation of wells in the alluvium of Cañon de Valle, sampling and tracer studies of area springs, sampling of water and sediment in Cañon de Valle and construction of 200-ft-deep mesa-top wells to intersect saturation that feeds the springs.

\subsubsection{Aggregate 6 Conceptual Model Refinement}

Figure 4.3-2 depicts general hydrogeologic conceptual model elements for aggregate 6. The Phase II RCRA investigations associated with the 260 Outfall confirm the existing conceptual model in general, but show it to be very complex in detail. Contaminant transport in the Bandelier Tuff is strongly controlled by fractures and the presence of surge beds between units. Thus, there is much uncertainty regarding the location and extent of perched saturated zones.

\subsubsection{Aggregate 6 FY99 Planned Activities}

There are no planned activities in Aggregate 6 for FY99. Plans call for drilling regional boreholes R-27 and R-28 in FYOO. Borehole R-27 is scheduled ahead of R-28. 


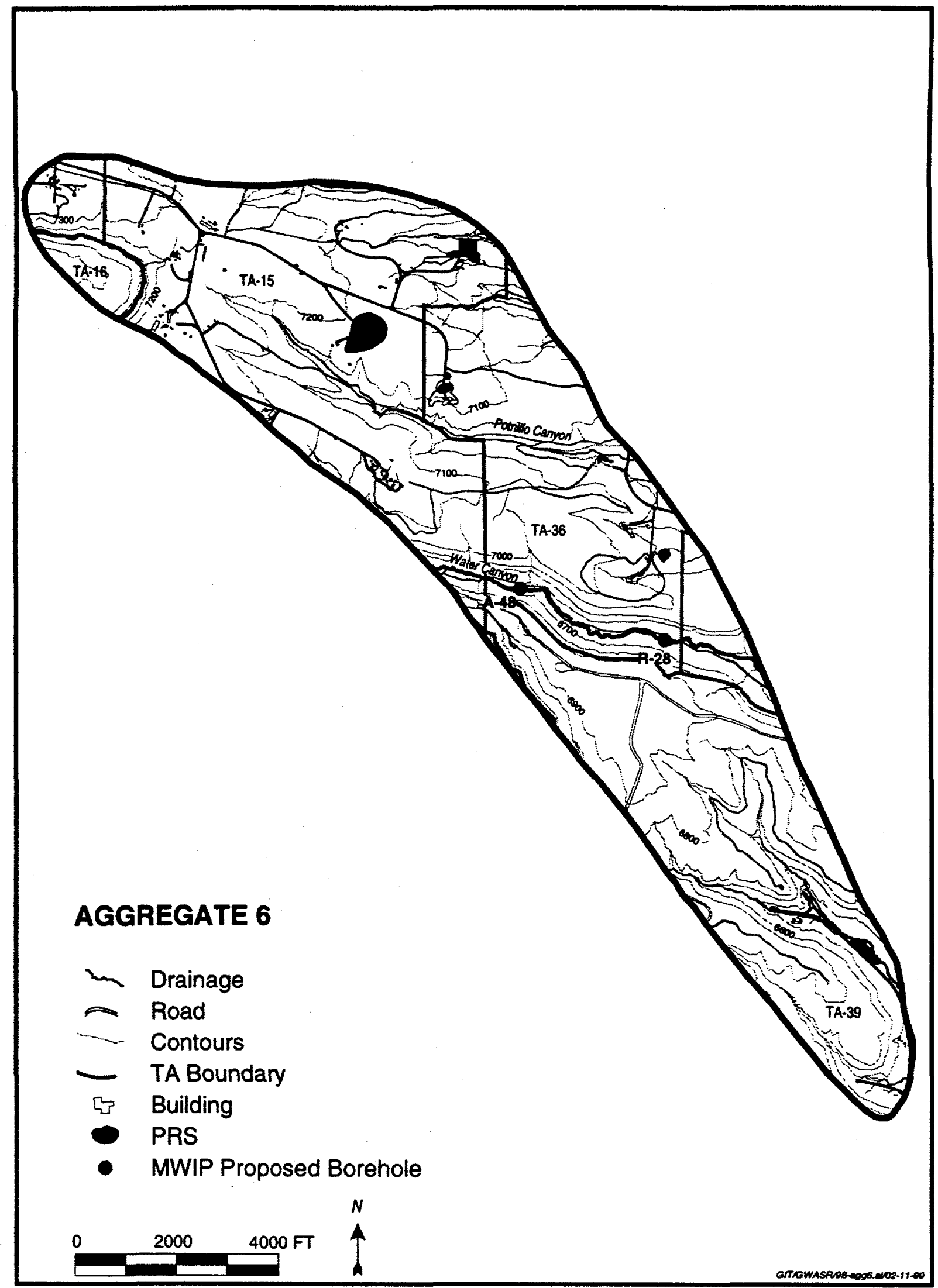

Figure 4.5-5. PRSs and proposed wells in Aggregate 6. 


\subsection{Aggregate 7}

Aggregate 7 is located in the central part of the Laboratory and contains both canyon-bottom and mesatop waste disposal sites. The aggregate includes portions of TA-35, TA-48, TA-50 and TA-55 on Pajarito Mesa as well as the adjacent Mortandad Canyon and its major tributary, Ten Site Canyon (Figure 4.7-1).

\subsubsection{Aggregate 7 FY98 Investigations}

The main ground-water investigation in FY98 was that associated with regional borehole R-15. Plans called for installing R-15 in two phases: (1) drilling by hollow-stem auger through the Cerro Toledo interval in FY98 and (2) completing the well by air-rotary methods in FY99. Phase 1 was successfully completed in FY98. The 8-in. hole not only penetrated the Cerro Toledo, but extended well into the Otowi Member of the Bandelier Tuff to a depth of $420 \mathrm{ft}$, an impressive achievement for augering. The lower part of the hole was then backfilled and the upper part reamed to a 20 -in. diameter so that 16 -in. surface casing could be set to a depth of $125 \mathrm{ft}$.

Borehole R-15 was continuously cored over the 420-ft length, except in the alluvium. Geologic units penetrated in Phase 1 drilling operations include, in descending order, alluvium, Qbt $1 \mathrm{~g}$ of the Tshirege Member of the Bandelier Tuff, volcaniclastic sediments and tephras of the Cerro Toledo interval, and the Otowi Member of the Bandelier Tuff (Table 4.7-1).

Table 4.7-1. Geologic Units Penetrated in Phase 1 at Borehole R-15

\begin{tabular}{|l|c|c|l|}
\hline \multicolumn{1}{|c|}{$\begin{array}{c}\text { Geologic } \\
\text { Unit }\end{array}$} & $\begin{array}{c}\text { Predicted Depth } \\
\text { of Basal Contact } \\
\text { (ft) }\end{array}$ & $\begin{array}{c}\text { Actual Depth } \\
\text { of Basal Contact } \\
\text { (ft) }\end{array}$ & \multicolumn{1}{|c|}{ Description } \\
\hline Alluvium & 20 & 16.5 & Fine silt and sand \\
\hline $\begin{array}{l}\text { Tshirege Member, } \\
\text { Bandelier Tuff }\end{array}$ & 57 & 65 & Nonwelded vitric ignimbrite \\
\hline Tsankawi Pumice Bed & 60 & 68 & Stratified pumice fall deposited \\
\hline Cerro Toledo interval & 130 & 120 & $\begin{array}{l}\text { Stratified sands and gravels to 105 } \mathrm{ft} \text {, sitt and fine sand } \\
\text { below }\end{array}$ \\
\hline $\begin{array}{l}\text { Otowi Member, } \\
\text { Bandelier Tuff }\end{array}$ & 410 & $420+$ & $\begin{array}{l}\text { Nonwelded vitric ignimbrite; distinctive pink oxidation at } \\
\text { top of unit (120 to 140 ft depth), gray to white below. }\end{array}$ \\
\hline Guaje Pumice Bed & 490 & Not drilled yet & $\begin{array}{l}\text { Phase 1 drilling ended at a depth of 420 ft in the Otowi } \\
\text { Member. }\end{array}$ \\
\hline
\end{tabular}

Subsamples of the core were taken for analysis of moisture content, hydraulic properties and chemistry. More specifically, 86 samples were taken for moisture content determination, 60 samples were preserved for hydraulic-property measurement and $\mathbf{4 7}$ samples were collected for geochemical analysis during Phase 1 at borehole R-15. 


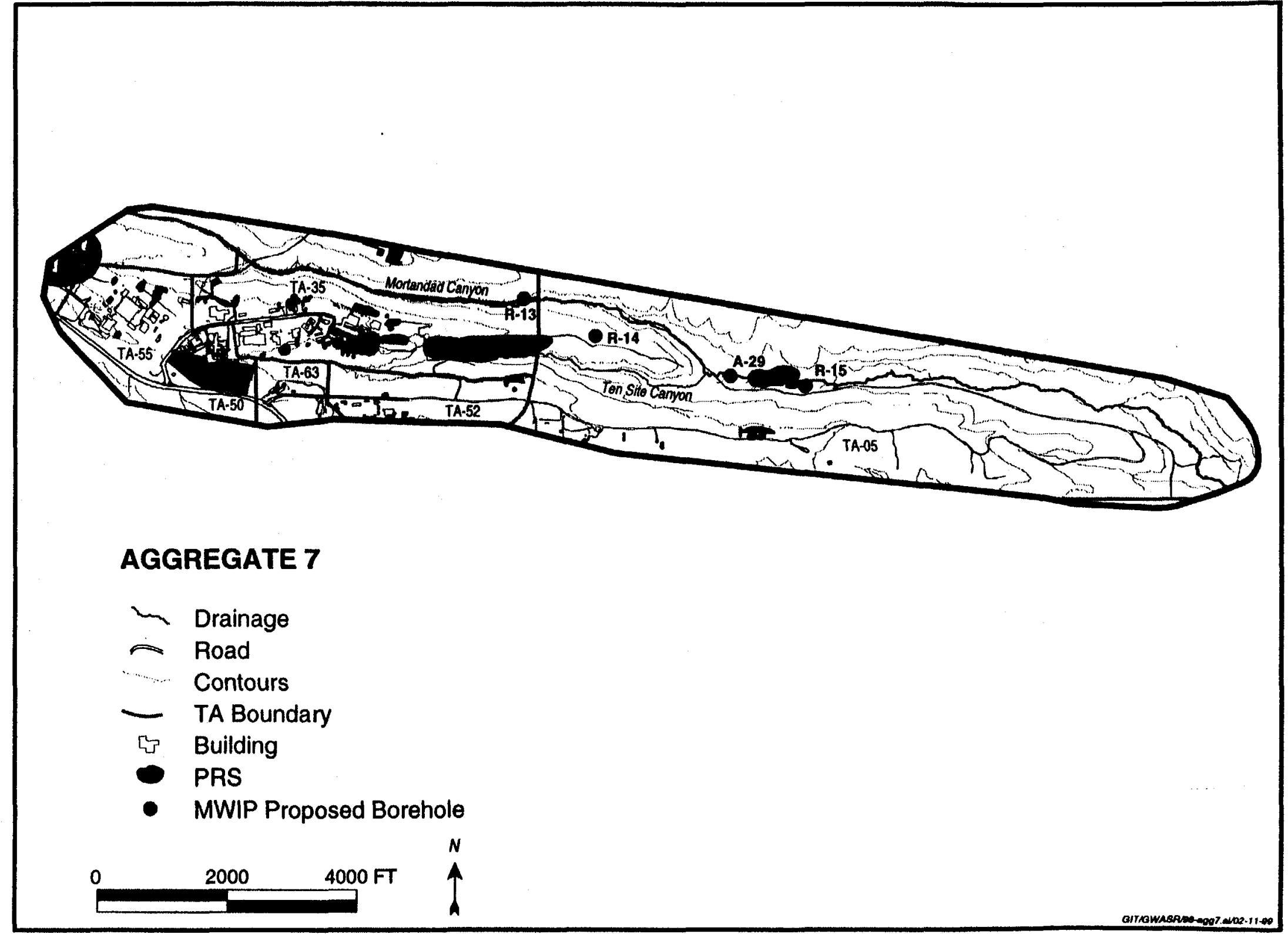

Flgure 4.7-1. PRSs and proposed wells in Aggregate 7. 
Twenty-three samples of core from R-15 were submitted for chemical and radiochemical analysis. These include one sample of the alluvium, five samples of unit $1 \mathrm{~g}$ of the Tshirege Member of the Bandelier Tuff, two samples of the Tsankawi Pumice Bed, seven samples of the Cerro Toledo interval and eight samples of the Otowi Member of the Bandelier Tuff. Analytes for the chemical analyses include RCRA metals, anions and percent organic carbon. Samples taken for radiochemistry are being analyzed for strontium-90, cesium-137, uranium isotopes, plutonium isotopes, americium-241, gross alpha, gross beta and gross gamma. Ten samples of soil water extracted from core will be analyzed for stable isotopes of oxygen and hydrogen and fourteen soil-water samples will be analyzed for tritium content. Results of these various analyses are not yet available.

\subsubsection{Aggregate 7 Conceptual Model Refinement}

Figure 4.7-2 depicts the general hydrogeologic conceptual model elements for aggregate 7 . Soil-water modeling and Phase 1 drilling at borehole R-15 contributed some interesting refinements to this conceptual model.

Simulations from a numerical modeling study of unsaturated groundwater movement beneath Mortandad Canyon showed water from the shallow perched water table could reach the regional aquifer in approximately ten to one hundred years, depending upon the assumed recharge rate used in the simulations (Dander 1998). Flow in the unsaturated zone may be predominantly downward; however, this conclusion is very dependent on the permeability contrast between lithologic units, the recharge rates assumed, and the continuity of the units.

As shown in Table 4.7-1, drilling at borehole R-15 essentially confirmed the existing geologic conceptual model. That is, not only are the expected stratigraphic units present, but their depths and thicknesses are more or less as predicted.

Observations at borehole R-15 provide another hydrologic refinement of the conceptual model. Perched water was expected in the Cerro Toledo interval. Although no saturation was encountered in that or any other unit during Phase 1 drilling, elevated moisture content was observed in two intervals. Whereas measured values average $10-20 \%$ in most of the bore, moisture content was determined to be $40 \%$ at the base of unit $1 \mathrm{~g}$ of the Tshirege Member of the Bandelier Tuff and $50 \%$ in the middle of the Cerro Toledo interval. These intervals may have been previously saturated but later drained to the observed moisture contents. Alternatively, the elevated moisture values may merely represent a slug of downwardmoving water from some recharge event that did not result in saturation. These observations suggest that, although the Cerro Toledo is in an optimal position for recharge at R-15, saturation is ephemeral and short-lived, occurring only after sufficient recharge events.

\subsubsection{Aggregate 7 FY99 Planned Activities}

Phase 2 of the borehole R-15 drilling and well installation will occur in FY99. This will involve drilling with the Barber rig, which will be moved in when operations at borehole R-25 permit. During this phase, saturation and hydrochemistry of the deeper units will be investigated.

Two alluvial wells, MCO 0.6 and MCO 7.2, are scheduled for installation in Mortandad Canyon to provide further information on alluvial groundwater. MCO-0.6 is scheduled for installation near the head of Mortandad Canyon. MCO 7.2 was installed below the sediment traps in early FY99. 


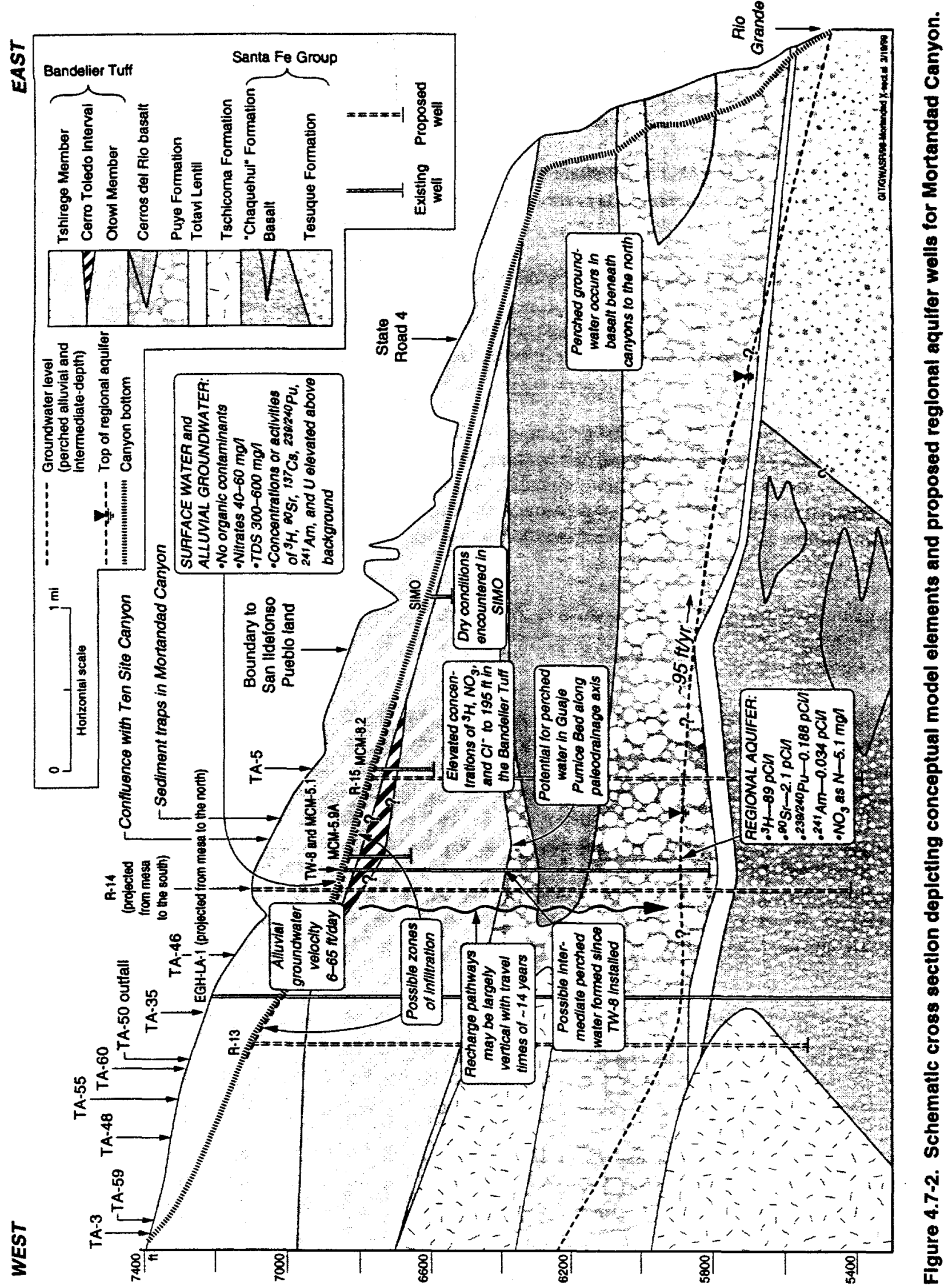




\subsection{Aggregate 8}

Aggregate 8 encompasses the area north of Pueblo Canyon and includes Bayo Canyon, Barrancas Canyon, Rendija Canyon, and Guaje Canyon (Figure 4.8-1). These canyons are relatively little affected by Laboratory operations, but may be sources of recharge for groundwater in the northern portion of the Laboratory. Aggregate 8 includes former TA-10 and parts of TA-74 in Bayo Canyon and Barrancas Canyon, respectively. There are also PRSs on Los Alamos County land in Rendija Canyon.

\subsubsection{Aggregate 8 FY97 and FY98 Investigations}

Between September 1997 and March 1998, four new municipal water supply wells were drilled and completed in Guaje Canyon as part of the Guaje Well Replacement Project. These new wells, named GR-1, GR-2, GR-3, and GR-4, are located adjacent to existing wells in the Guaje well field. This well field is on US Forest Service land in Guaje Canyon near the Rendija Canyon confluence. These new wells will replace seven aging wells that were placed into service between 1950 and 1964 . Five of these old wells will be plugged and abandoned in accordance with New Mexico State Engineer Office rules and regulations during FY99. The sixth well, G-1A, will be retained as a backup municipal water supply well. The seventh well has been transferred to ESH-18 for use as an observation well. All of the four new wells were drilled to $2,000 \mathrm{ft}$ below land surface and completed similarty. This completion includes 16-in.diameter production casings and screens fabricated from 304-stainless steel. The louvered, RoscoeMoss production screens have 0.375 -in. thick walls and 0.050 -in. slot openings. The annular spacing in the 26 -in.-diameter boreholes are filled with spherical, $98 \%$ pure quartz sand filter packs.

A great deal of new data has been collected during the construction of these replacement wells. These data include sample drill cuttings collected every ten feet, a complete suite of geophysical logs, constant rate and step-drawdown pump tests utilizing fully penetrating observation wells, spinner logs, and zonal water quality sampling. These data will be analyzed during FY99 and a special Guaje well field report will be issued summarizing important information.

Ownership of the water supply system, including all production wells, distribution lines, storage tanks, pump stations, chlorination units, and most of the water rights, was transferred to Los Alamos County by DOE during the summer of 1998.

\subsubsection{Aggregate 8 Conceptual Model Refinement}

All of the new Guaje replacement wells penetrate portions of the Puye Formation before encountering the underlying Santa Fe Group sediments. Spinner log tests confirm that the upper portions of the regional aquifer (i.e., the Chaquehui formation and interbedded basalts) account for more than $95 \%$ of well yields, while the lower Tesuque Formation accounts for less than $5 \%$ of yields. Although pump tests will not provide hydraulic conductivity values for individual water-bearing zones within the Santa Fe Group sediments, they do provide a qualitative interpretation for the vertical distribution of hydraulic conductivities. Preliminary analyses confirm that the Chaquehui formation has an important influence on flow and recharge in the regional aquifer. Preliminary analysis of the geological logs also shows the stratigraphy is similar to the original Guaje wells. 


\section{AGGREGATE 8}

in Drainage

$\approx$ Road

-...... Contours

- TA Boundary

- LANL Boundary

is Building

- PRS

- MWIP Proposed Borehole 


\subsubsection{Aggregate 8 FY99 Planned Activities}

Project activities remaining to be completed include the following: (1) completion of all pump test data and spinner log analyses; (2) completion of summary report; and (3) conversion of well G-3 to an observation well. Final project tasks include installation of pumps in new wells, construction of well houses, and abandonment of existing wells.

A recommendation was presented to FSS- 6 and Los Alamos County by ESH-18 for the development of an optimization and management model for operation of Guaje well field. This task is currently unfunded and unassigned. 


\subsection{SUMMARY OF FY99 PLANNED ACTIVITIES}

This section summarizes the planned activities for FY99 that are discussed in Section 4.0. The activities are described as either non-field or field activities.

\subsection{Non-Field Activities}

Non-field activities fall into one of three categories: project management, information management, and modeling. The planned activities for each category are listed below.

\subsubsection{Project Management}

- Hold GIT meetings on a biweekly basis, or as often as necessary to respond to program activities.

- Collect stakeholder input and regulatory direction in four quarterly meetings with DOE and NMED representatives.

- Ensure external program review by the EEG in two meetings and review of documents as necessary.

- Implement EEG recommendations as described in the EEG Action Plan (Nylander, 1999).

- Based on EEG recommendations, make efforts to reach consensus with NMED on two issues in FY99: (1) approach for continued investigations when contamination is detected in a regional aquifer well and (2) establishing the basis for groundwater quality limits. Initial discussions of proposed approaches for both of these issues will be discussed at the Quarterly Meeting (February 9, 1999).

\subsubsection{Information Management}

- Development and formalization of the "end state vision" by the HWPDB Project Leader.

- Development of a "Data and Records Management Plan" for the HWPDB by the HWPDB Project Leader.

- Consensus will be sought by the HWPDB Project Leader on the priorities for loading various data sets.

- A data repository will be created and loading or linking of existing data and new data will begin in FY99.

\subsubsection{Modeling}

- Continued calibration of the Los Alamos regional aquifer model will be accomplished by simulating transients in the aquifer.

- A high resolution sub-model of the regional model with transport capabilities for the Pajarito Plateau will be developed. 
- Continued development of the lower Los Alamos Canyon hydrologic model will be accomplished by incorporating newly generated data.

- Integration of hydrologic data into Stratamodel by utilizing geostatistics and other methods of parameter estimation to extend and qualify the data support and assist in developing a geohydrologic atlas.

- Migrate the current 3-D geologic model to Stratamodel and create FY99 3-D stratigraphic model by updating model with new data and completing the incorporation of basalt and Tshicoma flow units and the Chaquehui Formation into the model.

- Extend, refine, or create new grids in Stratamodel for specific applications such as detailed studies at MDAs or stream channels.

- Work with the New Mexico Bureau of Mines to produce the Frijoles Geologic Quadrangle from the existing 3-D database.

- Continued geochemical modeling of Los Alamos, Sandia, and Mortandad Canyons.

- Geochemical modeling of Cañon de Valle perched zones and regional aquifer.

- Additional geochemical modeling of barium speciation and solubility with water quality data from TA-16.

\subsection{Field Activities}

FY99 field activities are summarized by aggregate.

\subsubsection{Site-Wide (Aggregate 9) FY99 Planned Activities}

- Continued monitoring and data collection activities for near-surface hydrologic cycle components and groundwater levels at various depths.

- A water balance study in Los Alamos Canyon.

- Installation of gaging stations at canyon confluences and the Laboratory boundaries. This planned activity will provide water balance information for the hydrogeologic conceptual model, but will be funded through the Watershed Management Program.

\subsubsection{Aggregate 1 FY99 Planned Activities}

- Borehole R-9 will be completed as a single completion well at the top of the regional aquifer.

- Two alluvial wells, PAO-1 and PAO-2, will be installed in the western part of Pueblo Canyon.

- The GIT will examine the possibility of completing boreholes R-12, R-5, R-15, or R-31 in a west to east transect of three multi-port wells in the upper 500 to $700 \mathrm{ft}$ of the regional aquifer.

\subsubsection{Aggregate 2 FY99 Planned Activities}

- The TA-18 septic tank will be removed as part of a VCA plan. 
- TA-54 pore gas monitoring and neutron probe measurements will continue.

- Shallow isotope and chemical profiles (stable isotopes and chloride) will be measured to determine pattems of infiltration at TA-54.

- $\quad$ Further vegetative cover measurements will be made at TA-54.

- Lidar water vapor flux measurements will continue at TA-54.

- Neutron access tubes will be installed at a depth of about 1 meter prior to placing an asphalt pad over pit 7 at TA-54.

- $\quad$ Air pressure monitoring will continue in TA-54.

- Modeling and other work for the TA-54 Pilot Extraction Study Plan will be finalized. A design for a passive vapor extraction system will be prepared.

\subsubsection{Aggregate 3 FY9g Planned Activities}

- Area 2 investigations include drilling a vertical hole through an unused shaft, drilling an angled directional borehole undemeath Area 2, and installing an interflow monitoring trench in order to define the extent of vertical contamination.

\subsubsection{Aggregate 4 FY99 Planned Activities}

- Drill borehole R-31 in Ancho Canyon.

\subsubsection{Aggregate 5 FY99 Planned Activities}

- Complete of borehole R-25 as a multi-port well.

- Conduct a water and contaminant mass balance data collection effort in Cañon de Valle.

- $\quad$ Conduct a stable isotope $\left(\delta^{18} \mathrm{O}, \delta \mathrm{D}\right)$ tracer study to examine residence times of spring waters.

- Drill at least one alluvial well in Martin Canyon to investigate the hydrology.

- Implement an interim measure to remove highly contaminated material around the $\mathbf{2 6 0}$ outfall drainage.

\subsubsection{Aggregate 6 FY99 Planned Activities}

- There are no planned activities for FY99. Plans call for drilling boreholes R-27 and R-28 in FY00. Borehole R-27 is scheduled ahead of R-28.

\subsubsection{Aggregate 7 FY99 Planned Activities}

- Complete phase 2 of borehole R-15 drilling and well installation involving drilling with the Barber rig to investigate saturation and hydrochemistry of the deeper units.

- Install two alluvial wells, MCO 0.6 and MCO 7.2, in Mortandad Canyon. 


\subsubsection{Aggregate 8 FY99 Planned Activities}

- $\quad$ Complete Guaje water supply wells pump test and spinner log analyses.

- Complete Guaje water supply wells summary report.

- Develop an optimization and management model for operation of the Guaje well field.

- Convert well G-3 to an observation well.

\subsection{MWIP Borehole Status}

The priority and a summary of the MWIP borehole installation activities and well completion status is provided here in tabular form to consolidate the information provided throughout this report. Table 5.3-1 provides a list of boreholes ordered by priority of installation. Table 5.3-2 captures FY98 changes in installation scheduling as published in the Hydrogeologic Workplan (LANL 1998) and provides the status of drilling activities and decisions on well completion. Figure 4-1 shows the location and completion status of the proposed regional aquifer boreholes. Figure 5.3-1 provides a Gantt chart of the well completion schedule. 
Table 5.3-1. MWIP Proposed Regional Aquifer Boreholes Priority and Start Dates

\begin{tabular}{|c|c|c|c|}
\hline Priority & Borehole & $\begin{array}{l}\text { Funding } \\
\text { Source }\end{array}$ & $\begin{array}{c}\text { Current } \\
\text { Start Date }\end{array}$ \\
\hline 1. & $R-9$ & ER & Sep FY98 \\
\hline 2. & $R-12$ & ER & Mar FY98 \\
\hline 3. & R-25 & NWT & Jul FY98 \\
\hline 4. & $R-15$ & ER & Aug FY98 \\
\hline 5. & R-31 & NWT & Aug FY99 \\
\hline 6. & R-27 & ER & Nov FYOO \\
\hline 7. & $R-19$ & ER & Feb FY00 \\
\hline 8. & R-5 & NWT & May FYOO \\
\hline 9. & $R-28$ & NWT & Aug FYOO \\
\hline 10. & R-22 & ER & Nov FY01 \\
\hline 11. & $R-32$ & $\mathrm{NWT}$ & Feb FY01 \\
\hline 12. & R-7 & ER & May FY01 \\
\hline 13. & $R-1$ & NWT & Aug FY01 \\
\hline 14. & $R-18$ & ER & Nov FY02 \\
\hline 15. & $R-8$ & NWT & Feb FY02 \\
\hline 16. & $R-10$ & ER & May FYO2 \\
\hline 17. & $R-2$ & NWT & Aug FY02 \\
\hline 18. & R-3 & ER & Nov FYO3 \\
\hline 19. & R-20 & NWT & Feb FY03 \\
\hline 20. & $R-4$ & ER & May FY03 \\
\hline 21. & $R-14$ & NWT & Aug FY03 \\
\hline 22. & R-13 & ER & Nov FYO4 \\
\hline 23. & R-11 & NWT & Feb FYO4 \\
\hline 24. & R-17 & ER & May FY04 \\
\hline 25. & R-6 & NWT & Aug FY04 \\
\hline 26. & R-23 & ER & Nov FY05 \\
\hline 27. & R-29 & NWT & Feb FY05 \\
\hline 28. & $R-16$ & NWT & Feb FY05 \\
\hline 29. & R-21 & ER & May FY05 \\
\hline 30. & R-26 & NWT & May FY05 \\
\hline 31. & $R-24$ & NWT & Aug FYOS \\
\hline 32. & R-30 & ER & Aug FY05 \\
\hline
\end{tabular}


Table 5.3-2. Status of MWIP Proposed Reglonal Aqulfer Boreholes

\begin{tabular}{|c|c|c|c|c|c|}
\hline Borehole & $\begin{array}{l}\text { Original } \\
\text { Stant Date }\end{array}$ & $\begin{array}{c}\text { Current } \\
\text { Start Date }\end{array}$ & $\begin{array}{l}\text { FY98 } \\
\text { Stutus }\end{array}$ & $\begin{array}{l}\text { Funding } \\
\text { Source }\end{array}$ & Status of Installed Boreholes/Aationale of Proposed Boreholes \\
\hline R-9 & FY98 & FY98 & $\begin{array}{l}\text { Borehole drilled, } \\
\text { well completion } \\
\text { scheduled in } \\
\text { FY99 }\end{array}$ & ER & $\begin{array}{l}\text { Borehole R-9 has been installed at the eastern Laboratory boundary in Los Alamos Canyon, but not yet completed } \\
\text { as a single-completion monitoring well. It was designed to provide water-quality and water-level data for potential } \\
\text { intermedlate perched zones and for the regional aquifer downgradient of Aggregate } 1 \text {. Borehole R-9 encountered } \\
\text { two perched intermediate saturated zones at } 180 \text { and } 275 \mathrm{fl} \text {. Addltionally, three separate saturated zones (579, } \\
615 \text {, and } 624 \mathrm{t} \text { ) were encountered above the reglonal aquiter (688 fi). The stratigraphlc, hydrologlc, and } \\
\text { geochemical description of } A-9 \text { is included in Section } 4.1 .1 \text {. }\end{array}$ \\
\hline R-12 & FY98 & FY98 & $\begin{array}{l}\text { Borehole drilled, } \\
\text { well completion } \\
\text { scheduled in } \\
\text { FYo0 }\end{array}$ & EA & 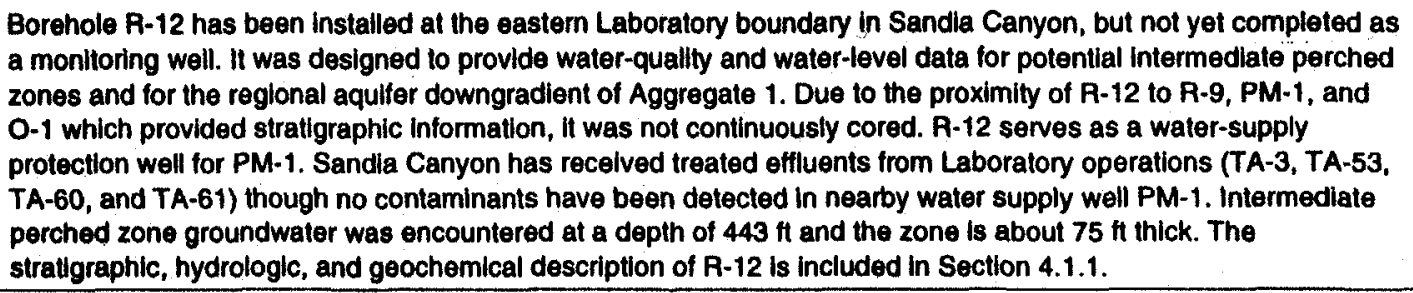 \\
\hline R-25 & FY98 & FY98 & $\begin{array}{l}\text { Borehole started } \\
\text { in FY98, well } \\
\text { completion } \\
\text { scheduled in } \\
\text { FY99 }\end{array}$ & NWT & $\begin{array}{l}\text { Borehole R-25 has been partlally Installed as a multipurpose borehole located adjacent to MDA P in Aggregate } 5 . \\
\text { Core collected from this borehole will support slte-wide studles of the hydrogeologic framework because it is } \\
\text { located in a largely uncharacterized area in the southwest part of the Laboratory. It was not continuously cored. } \\
\text { Thls hole will provide critical information about the depth to the regional aquiler for Itis area. R-25 will also provide } \\
\text { water quality data for Intermedlate perched zones and the reglonal aquifer downgradient from MDA P and from } \\
\text { other release sites further west in the Cañon de Valle watershed. Springs issuing from the upper Bandelier Tutf in } \\
\text { this area are contaminated with HE, nitrate, and barium. R-25 is part of a southeasterly traverse of reference wells } \\
\text { that includes R-2B and R-32 and a north-south traverse that includes R-6. }\end{array}$ \\
\hline R-15 & FYOO & FY98 & $\begin{array}{l}\text { Started with } \\
\text { hollow-stem } \\
\text { auger in late } \\
\text { FY98, completion } \\
\text { with Barber drill } \\
\text { rig in Spring. } \\
1999, \text { after } \\
\text { completion of } \\
\text { R-25 } \\
\end{array}$ & ER & $\begin{array}{l}\text { Borehole R-15 has been partlally installed in Mortandad Canyon downstream from active and inactive outfalls at } \\
\text { TA-5, TA-35, TA-48, TA-50, TA-52, TA-55, and TA-60. The presence of intermediate perched zones within } \\
\text { Aggregate } 7 \text { will be Investigated and, if present, characterized. Characterization data from R-15 are critical for } \\
\text { supporting the TA-50 Discharge Plan and for addressing cltizens concerns about releases in Mortandad Canyon. } \\
\text { R-15 may replace TW-8 completed in } 1960 \text {. The locatlon of R-15 is described in the ER Work Plan for Mortendad } \\
\text { Canyon (LANL, 1997). }\end{array}$ \\
\hline R-31 & FY01 & FY99 & $\begin{array}{l}\text { Planned lo start } \\
\text { after completion } \\
\text { of R-15 }\end{array}$ & NWT & $\begin{array}{l}\text { Site-wide characterization borehole A-31 is planned for installation downgradient of open burning/open delonation } \\
\text { sltes in Aggregate } 6 \text { and upgradient of firing sites in Aggregate } 4 \text {. The primary objective of this borehole is to } \\
\text { provide water quality data for potential intermediate perched zones and for the regional aquifer. This is a part of } \\
\text { the Laboratory with no well control, and data from this borehole is critical to the modeling actlvities. This borehole } \\
\text { will contribute to the optimizallon of long-term monitoring wells for Aggregates } 4 \text { and } 6 \text { by placing better } \\
\text { constraints on the geometry of the regional aquifer in this area. }\end{array}$ \\
\hline
\end{tabular}


Table 5.3-2. Status of MWIP Proposed Boreholes (continued)

\begin{tabular}{|c|c|c|c|c|c|}
\hline Borehole & $\begin{array}{l}\text { Original } \\
\text { Start Date }\end{array}$ & $\begin{array}{c}\text { Current } \\
\text { Start Date }\end{array}$ & $\begin{array}{l}\text { FY98 } \\
\text { Status }\end{array}$ & $\begin{array}{l}\text { Funding } \\
\text { Source }\end{array}$ & Status of Installed Boreholea/Ratlonale of Proposed Boreholes \\
\hline R-27 & FYOO & FYOO & $\begin{array}{l}\text { Suggested re- } \\
\text { prloritization by } \\
\text { NMED }\end{array}$ & ER & 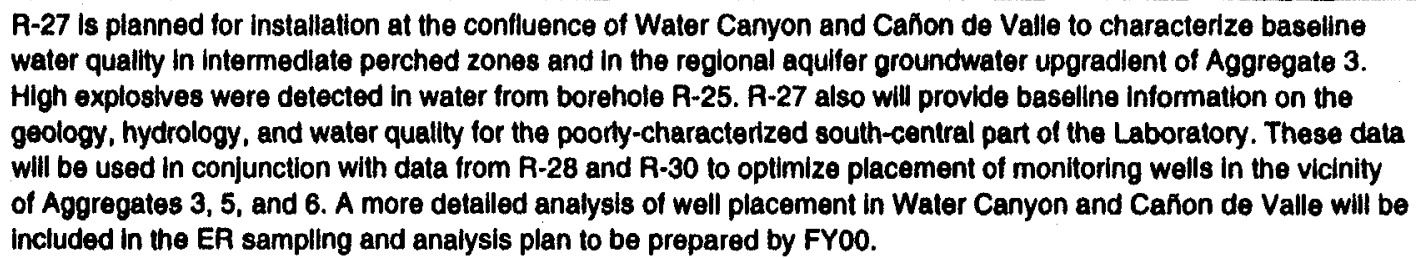 \\
\hline R-19 & FY01 & FYOO & Planned & ER & $\begin{array}{l}\text { R-18 is planned tor installation to provide information about intermediale perched zone groundwater, depth to the } \\
\text { reglonal aquifer, and water quality in the poorly-characterized central part of the Laboratory. R-19 provides } \\
\text { downgradient water quallty data for release sites in upper Pajarito Canyon and upgradlent data for TA-18. R-19 } \\
\text { will help constraln the locallon of the axis of the south-draining pre-Bandeller paleo-drainage which trends through } \\
\text { thls area. }\end{array}$ \\
\hline R-5 & FYOO & FYOO & Planned & NWT & 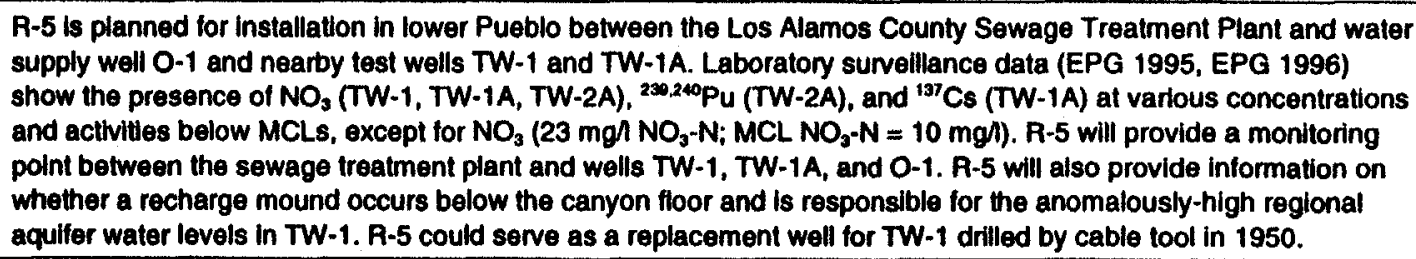 \\
\hline R-28 & FY01 & FYoO & Planned & NWT & $\begin{array}{l}\text { R-28 is planned for installation as a multipurpose borehole in the middle reach of Water Canyon. This borehole will } \\
\text { provide water-quality information for potential intermedlate perched zones and for the regional aquifer beneath } \\
\text { PRSs in Aggregale 6, and It will provide information for optimizing the placement of monitoring wells in this part of } \\
\text { the Laboratory. R-28 is presently scheduled to be completed as a Type } 3 \text { well, but the option is preserved to } \\
\text { advance these boreholes to a total depth of } 4000 \text { th and to include multiple completions of the well if funding } \\
\text { agencles decide further characterization of reglonal aqulfer groundwater resources is required. }\end{array}$ \\
\hline R-22 & FY98 & FY01 & Funding delay & ER & $\begin{array}{l}\text { R-22 is planned for Installation near the southeastern Laboratory boundary in Pajarito Canyon to provide water- } \\
\text { qually and water-level data for potential intermediate perched zones and for the reglonal aquifer downgradient of } \\
\text { Aggregate 2. Aggregate } 2 \text { includes MDA L and MDA G. In addition, this location is downgradient of numerous } \\
\text { other Laboratory lechnical areas which released HE, radionuclides, organic solvents, and inorganic solutes. Large } \\
\text { springs (e.g. Pajarito Spring) discharge from basalts in lower Pajarito Canyon into White Rock Canyon. Water- } \\
\text { quality characteristics will be compared for R-22 and the springs to evaluate whether these groundwater-bearing } \\
\text { zones are hydrologically connected. }\end{array}$ \\
\hline R.32 & FY01 & FY01 & Planned & NWT & $\begin{array}{l}\text { R-32 ls planned for Installation west of Ancho Spring in lower Ancho Canyon. This borehole is designed to provide } \\
\text { baseline information on the geology, hydrology, and water qually for the poorly studled southeastern boundary of } \\
\text { the Laboratory. II is located within Aggregate } 4 \text { and will provide water-quality and water-level data for intermediale } \\
\text { perched zones and the reglonal aquiler in thls area. Waler quality data for R-32 will be compared to similar dala } \\
\text { for springs in White Rock Canyon lo Identify potential groundwater flow paths near the Rio Grande. Waler samples } \\
\text { from Ancho Spring contain HE and depleted U which probably originated from firing sites in Aggregates } 4 \text { or } 6 \text {. }\end{array}$ \\
\hline
\end{tabular}


Table 5.3-2. Status of MWIP Proposed Boreholes (continued)

\begin{tabular}{|c|c|c|c|c|c|}
\hline Borehole & $\begin{array}{l}\text { Original } \\
\text { Start Date }\end{array}$ & $\begin{array}{c}\text { Current } \\
\text { Start Date }\end{array}$ & $\begin{array}{l}\text { FY98 } \\
\text { Status }\end{array}$ & $\begin{array}{l}\text { Funding } \\
\text { Source }\end{array}$ & Status of Installed Boreholes/Aationale of Proposed Boreholes \\
\hline R-7 & FY98 & FY01 & $\begin{array}{l}\text { Delayed due to } \\
\text { NMED requested } \\
\text { acceleration of } \\
\text { R-15 }\end{array}$ & ER & $\begin{array}{l}\text { R-7 is planned for installation in upper Los Alamos Canyon to provide water-quality and water-level measurements } \\
\text { for the intermedlate perched zones and the regional aquifer in an area of Los Alamos Canyon that is in close } \\
\text { proximity to release sites of contaminated effluent (TA-2 and TA-21). R-7 is located between existing boreholes } \\
\text { LADP-3 and LAOI(A)1.1 in Los Alamos Canyon. These existing boreholes, and H-19 located west of Los Alamos } \\
\text { Canyon brige, penetrated a 5- } 1022-\text {-tt thick perched intermedlate zone. The water quallty data suggest that the } \\
\text { perched zone is recharged both by inflitration from overlying alluvium and by recharge sources in the mountains to } \\
\text { the west. R-7 is sited in this area of suspected recharge and will provide information about stratigraphic and } \\
\text { structural controls on infiltration. Also, R-7 will penetrate the full extent of saturation at the top of the Puye } \\
\text { Formation and identify deeper intermediate perched zones benealh Los Alamos Canyon. Hydrologic and geologic } \\
\text { propertles of pre-Bandeller units in R-7 will be used for ER Project assessments of mesa-top sites at TA-21, } \\
\text { TA-53, and TA-73. }\end{array}$ \\
\hline R-1 & FY01 & FY01 & Planned & NWT & $\begin{array}{l}\text { R-1 is planned for installatlon as a multipurpose borehole located north of Aggregate } 1 \text { in Rendija Canyon. R-1 is } \\
\text { slied along the northward projectlon of Purtymun's (1995) mid-Mlocene high-permeablity zone at the lop of the } \\
\text { Santa Fe Group, and this borehole could signiflcantly extend the known northern limit of this important water- } \\
\text { supply feature. This borehole is presently scheduled to be completed as a Type } 3 \text { well, but the option is preserved } \\
\text { to advance the boreholes for these wells to a total depth of } 4000 \text { ft and to include multiple complelions of the wells } \\
\text { If funding agencies decide further characterlzatlon of reglonal aqulfer groundwater resources is required. Water- } \\
\text { level and water quality data from this borehole will be used to test hypotheses concerning possible recharge to the } \\
\text { regional aquifer from the north. R-1 is part of a north-south traverse of reference wells that includes R-14 and } \\
\text { R-28. }\end{array}$ \\
\hline R-18 & FY99 & FY02 & Funding delay & ER & $\begin{array}{l}\text { R-18 is planned for installatlon above the confluence of Pajarlto and Twomile Canyons to provide information } \\
\text { about intermediate perched zone groundwater, depth to the regional aquifer, and water quality of perched zones } \\
\text { and the regional aquifer in the poorly-characterized west-central part of the Laboratory. It is located downstream } \\
\text { from Laboratory release sites at TA-8, TA-9, TA-14, TA-22, TA-40, and TA-69, but is in an area that has not been } \\
\text { characterized for either groundwater or contaminants. The occurrence of surface flow through most of the year } \\
\text { indicates perched alluvial groundwater is present in this part of the canyon. }\end{array}$ \\
\hline R-8 & FYOO & FY02 & Planned & NWT & 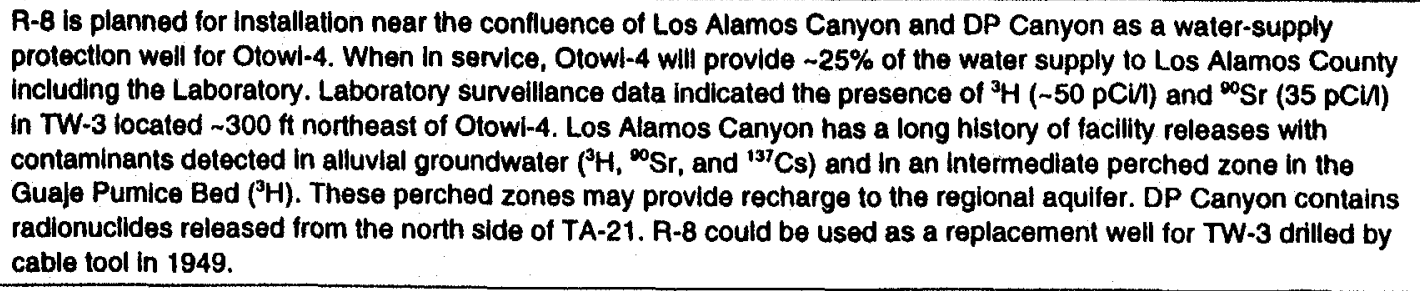 \\
\hline
\end{tabular}


Table 5.3-2. Status of MWIP Proposed Boreholes (contlnued)

\begin{tabular}{|c|c|c|c|c|c|}
\hline Borehole & $\begin{array}{c}\text { Orlginal } \\
\text { Start Date }\end{array}$ & $\begin{array}{c}\text { Current } \\
\text { Start Date }\end{array}$ & $\begin{array}{l}\text { FY98 } \\
\text { Status }\end{array}$ & $\begin{array}{l}\text { Funding } \\
\text { Source }\end{array}$ & Status of Installed Boreholea/Ratlonale of Proposed Boreholes \\
\hline R-10 & FYOO & FY02 & Planned & ER & $\begin{array}{l}\text { A-10 is planned for Installation in upper Sandla Canyon to provide water-quality information for a potential } \\
\text { intermediate perched zone in the Guaje Pumlce Bed. The large intermedlate perched zone in Los Alamos Canyon } \\
\text { is located in this horlzon and contains significant }{ }^{3} \mathrm{H} \text {. This perched zone appears to be largely confined to the area } \\
\text { beneath Los Alamos Canyon west of TA-21 (the Guaje Pumice Bed was not saturated in boreholes } 21-2523 \text { and } \\
\text { LADP-4 north of Los Alamos Canyon), but structure contour maps (Broxton and Reneau 1996; Davis et al. 1996) } \\
\text { suggest that the gradient of the perching layer changes in the vicinity of R-7 and R-10, and water perched in this } \\
\text { zone will move southward along the axis of a large pre-Bandeller paleo-drainage. R-10 is designed to investigate } \\
\text { the southward extension of this perched system from the Los Alamos Canyon area. }\end{array}$ \\
\hline R-2 & FYOO & FY02 & Planned & NWT & 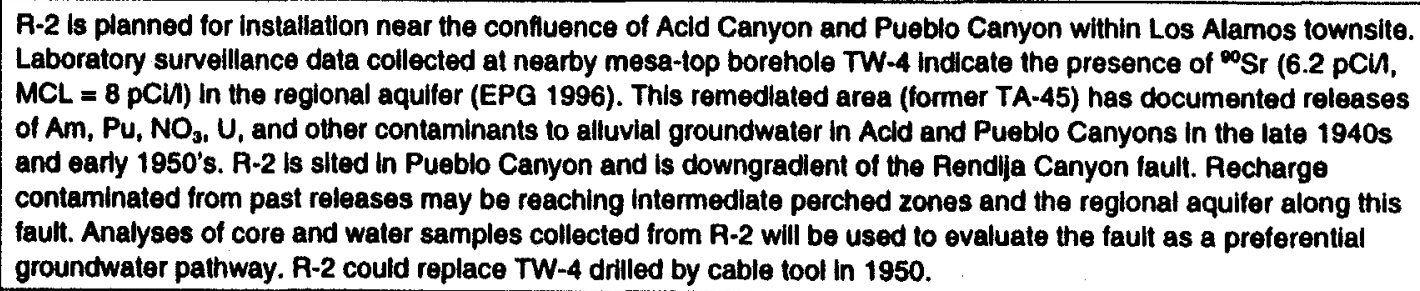 \\
\hline R-3 & FY99 & FY03 & Funding delay & EA & 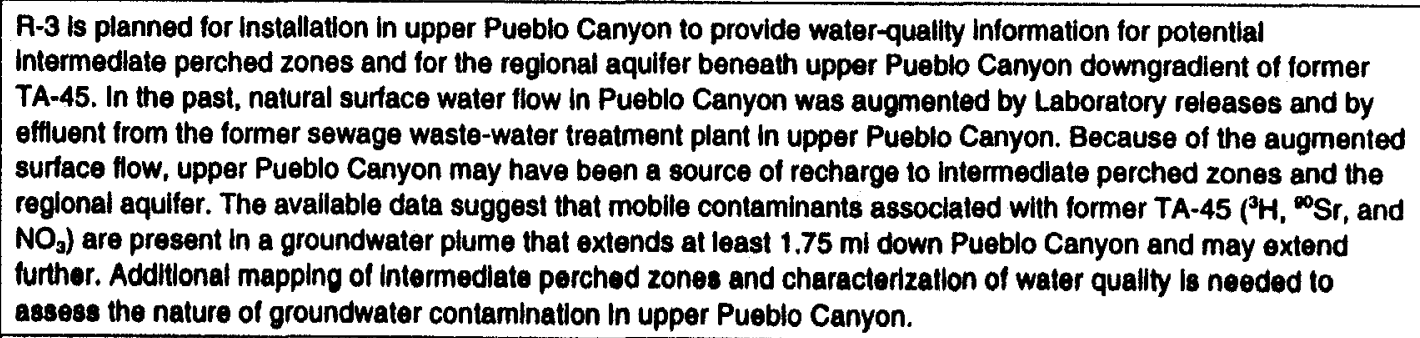 \\
\hline R-20 & FY02 & FY03 & Planned & NWT & 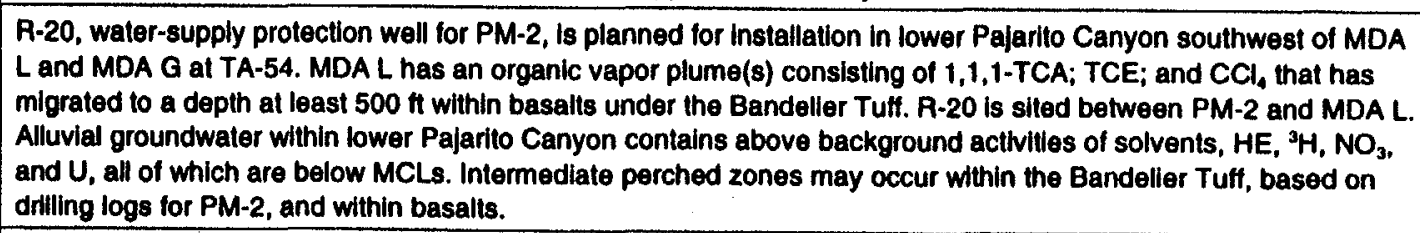 \\
\hline A-4 & FY01 & FY03 & Planned & ER & $\begin{array}{l}\text { R-4 is planned for installation to provide water-quality and water-level iniormation for potential intermediate } \\
\text { perched zones and for the reglonal aquifer beneath middie Pueblo Canyon. R-4 will provide information about the } \\
\text { downgradlent extent of groundwater contaminatlon from former TA-45. This borehole is located between TW-1A } \\
\text { and TW-2A, both of which were completed in intermedlate perched zones containing contaminant levels that are } \\
\text { above background levels. R-4 will place constraints on the lateral extent of the perched zone(s) and ldentify } \\
\text { deeper perched zones within the Puye Formation and basalts in mlddle Pueblo Canyon near the northem } \\
\text { Laboratory boundary. R-4 will also characterize groundwater water quality upgradlent of the county's Bayo } \\
\text { Sewage Treatment Plant. }\end{array}$ \\
\hline
\end{tabular}


Table 5.3-2. Status of MWIP Proposed Boreholes (continued)

\begin{tabular}{|c|c|c|c|c|c|}
\hline Borehole & $\begin{array}{c}\text { Original } \\
\text { Start Date }\end{array}$ & $\begin{array}{c}\text { Current } \\
\text { Start Date }\end{array}$ & $\begin{array}{l}\text { FY98 } \\
\text { Status }\end{array}$ & $\begin{array}{l}\text { Funding } \\
\text { Source }\end{array}$ & Status of Installed Boreholes/Rationale of Proposed Boreholes \\
\hline R-14 & FY02 & FY03 & Planned & NWT & 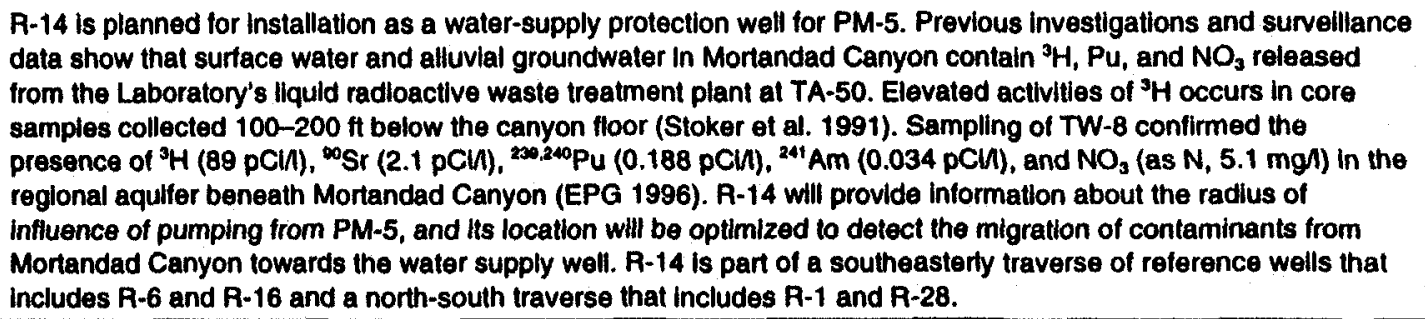 \\
\hline$R-13$ & FYo1 & FY04 & Planned & ER & $\begin{array}{l}\text { R-13 is planned for installation to provide water-quality and water-level data for potential intermediate perched } \\
\text { zones and for the regional aquiler within Aggregate } 7 \text {. Laboratory surveillance dala collected in Mortandad Canyon } \\
\text { show elevated concentrations or acilvities of } \mathrm{NO}_{3},{ }^{3} \mathrm{H},{ }^{00} \mathrm{Sr},{ }^{137} \mathrm{Cs},{ }^{230,240} \mathrm{Pu},{ }^{241} \mathrm{Am} \text {, and } \mathrm{U} \text { in ephemeral surface } \\
\text { water and in alluvial groundwater. Vertical migration of }{ }^{3 \mathrm{H}} \text { beneath the canyon floor has been documented by } \\
\text { Stoker et al. (1991). }\end{array}$ \\
\hline A-11 & FY03 & FY04 & Planned & NWT & $\begin{array}{l}\text { A-11, planned for installation as a water-supply protectlon well for PM-3, is located in middle Sandia Canyon east } \\
\text { of the TA-72 firing range. PM-3 is downgradient from source terms with a long history of releases at TA-53 and } \\
\text { TA-21. R-11 is located between PM-3 and the potentlal release sites. R-11 will also provide information about } \\
\text { groundwater gradients near PM-3, whlch has water levels that are anomalously high compared to elevations } \\
\text { expected from regional water level maps. }\end{array}$ \\
\hline R-17 & FYO2 & FY04 & Planned & ER & $\begin{array}{l}\text { A-17 is planned for installation in Twomlle Canyon, a major tributary to Pajarito Canyon, to provide information } \\
\text { about intermedlate perched zones, depth to the reglonal aquifer, and water quality of intermediate perched zones } \\
\text { and the reglonal aqulfer in the poorly-characterized northwest part of the Laboratory. It is located downstream from } \\
\text { Laboratory release sltes at TA-3, TA-6, TA-58, TA-59, TA-62, and TA-69, but is in an area that has not been } \\
\text { characterized for elther groundwater or contaminants. R-17 will also provide upgradient water-quality information } \\
\text { for Aggregate 7. }\end{array}$ \\
\hline R-6 & FY03 & FY04 & Planned & NWT & $\begin{array}{l}\text { R-6, planned for installation in upper Los Alamos Canyon, is designed to provide baseline information about the } \\
\text { geology, hydrology, and water quallty for the western boundary of the Laboratory. Thls borehole will delermine } \\
\text { background water quality for intermediate perched zones and the regional aquiler upgradient of Aggregate } 1 \text {. It } \\
\text { also will provide information about the depth to the reglonal aquifer for the western part of the Laboratory, and } \\
\text { contribute to the constructlon of accurate groundwater maps for placing monitoring wells in this part of the } \\
\text { Laboratory. R-6 is part of a southeasterly traverse of reference wells that includes R-14 and R-16 and a north- } \\
\text { south traverse that Includes R-25. }\end{array}$ \\
\hline R-23 & FYO2 & FY05 & Planned & ER & $\begin{array}{l}\text { R-23, located near the southeastem Laboratory boundary, is planned for installation to provide water-quality and } \\
\text { water-level data for potential intermedlate perched zones and for the regional aquifer downgradient of active firing } \\
\text { slies in Potrillo Canyon. R-23 is sited within a hydrological sink, a broad area of infiltration on the canyon floor that } \\
\text { typically marks the easternmost occurrence of surface water flow in this canyon. R-23 will evaluate the } \\
\text { hydrological sink as a possible recharge zone for perched groundwater and for the regional aquiler. }\end{array}$ \\
\hline
\end{tabular}


Table 5.3-2. Status of MWIP Proposed Boreholes (continued)

\begin{tabular}{|c|c|c|c|c|c|}
\hline Borehole & $\begin{array}{c}\text { Original } \\
\text { Start Dato }\end{array}$ & $\begin{array}{c}\text { Current } \\
\text { Start Date }\end{array}$ & $\begin{array}{l}\text { FY98 } \\
\text { Status }\end{array}$ & $\begin{array}{l}\text { Funding } \\
\text { Source }\end{array}$ & Stutus of Installed Boreholea/Retlonale of Proposed Boreholes \\
\hline A-29 & FY03 & FY05 & Planned & NWT & $\begin{array}{l}\text { R-29 is planned for installation in lower Water Canyon. II will provide information aboul the depth to the regional } \\
\text { aquifer in a poorly-characterized area, and the water-level data will be used to optimize the placement of } \\
\text { downgradlent monltoring wells along the eastern Laboratory boundary. Water quality data from perched and } \\
\text { regional groundwaters in R-29 will be compared to simllar data for springs in White Rock Canyon to identity } \\
\text { potentlal groundwater flow paths near the Rlo Grande. }\end{array}$ \\
\hline R-16 & FY03 & FY05 & Planned & NWT & 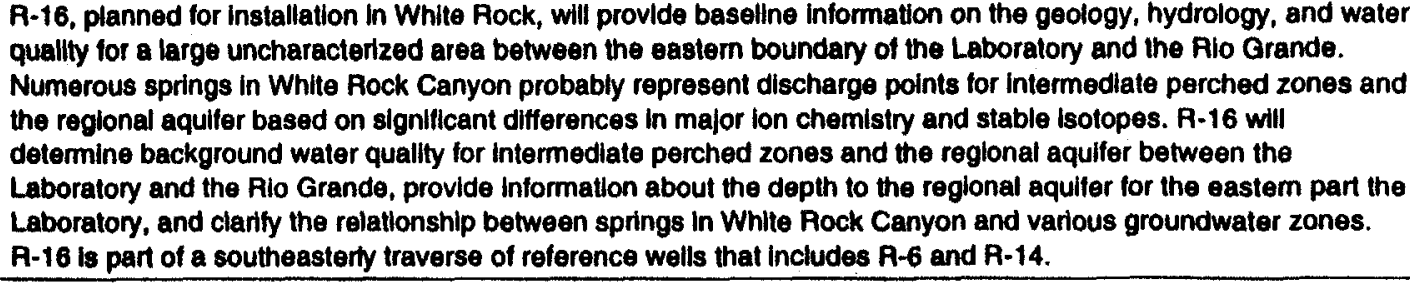 \\
\hline R-21 & FY02 & FY05 & Planned & ER & $\begin{array}{l}\text { R-21 is planned for installation to evaluate and monitor hydrologic and geochemical conditlons in the reglonal } \\
\text { aquiler beneath MDA L. The ER Project has delected dense non-aqueous phase vapors beneath MDA L: these } \\
\text { organic vapors have migrated through fractures in the Bandeller Tuff and the underlying basalts to a depth of } 500 \\
\text { it. }\end{array}$ \\
\hline R-26 & FY02 & FY05 & Planned & NWT & $\begin{array}{l}\text { R-26 is planned for Installation near the trace of the Pajarito fault system near the southwest comer of the } \\
\text { Laboratory. Thls borehole will provide water-quality and water-level dala for perched systems and the regional } \\
\text { aquifer on the downthrown block of the Pajarlto fault system. Numerous springs, including the large Water Canyon } \\
\text { Gallery, lseue from the Bandelier Tult in Water Canyon. The locatlon and occurrence of perched water and water } \\
\text { level data for the reglonal aquiler, when compared with similar data from R-24 and R-25 on the downthrown and } \\
\text { upthrown blocks, respectlvely, will be used to evaluate the influence of the Pajarito fault system on the reglonal } \\
\text { plezometric surface and provide information about its role as a recharge zone. Water quality data from } \\
\text { intermedlate perched zone and regional groundwater In R-26 will define background conditions in a large wet } \\
\text { canyon upgradlent from the Laboralory, and in particular for Aggregate 5. These background geochemical data } \\
\text { will be used to define potentlal impacts on groundwater from Laboratory facilities and to provide input data for } \\
\text { geochemlcal and hydrological modeling of dilferent groundwater systems. }\end{array}$ \\
\hline R-24 & FY02 & FY05 & Planned & NWT & $\begin{array}{l}\text { R-24 is planned for Installatlon near the trace of the Pajarito fault system west of Aggregate 5. This borehole will } \\
\text { provide water-quality and water-level data for Intermedlate perched zones and the reglonal aquifer on the } \\
\text { upthrown block of a major spray of the Pajarlto fault system. The location and occurrence of perched water and } \\
\text { water level data for the reglonal aquifer, when compared with simllar data from R-25 and R-26 on the downthrown } \\
\text { block, will be used to evaluale the influence of the Pajerito fault system on the regional plezometric surface and } \\
\text { provide information about its role as a recharge zone. R-24 will be used to establish boundary conditions on the } \\
\text { western side of the Laboratory for numerical models of groundwater flow. Water quality data from intermediate } \\
\text { perched zone and regional groundwater in R-24 will define background conditions upgradient from the Laboratory, } \\
\text { and in particular for Aggregate 5. These background geochemical dala will be used to define potential impacts on } \\
\text { groundwater from Laboratory laclitles and to provide inpul data for geochemical and hydrological modeling of } \\
\text { different groundwater systems. }\end{array}$ \\
\hline
\end{tabular}


Table 5.3-2. Status of MWIP Proposed Boreholes (continued)

\begin{tabular}{|l|l|l|l|l|l|}
\hline Borehole & $\begin{array}{c}\text { Original } \\
\text { Start Date }\end{array}$ & $\begin{array}{c}\text { Current } \\
\text { Stant Date }\end{array}$ & $\begin{array}{c}\text { FY98 } \\
\text { Status }\end{array}$ & $\begin{array}{c}\text { Funding } \\
\text { Source }\end{array}$ & Status of Inatalled Boreholes/Rationale of Proposed Boreholes \\
\hline R-30 & FY02 & FY05 & Planned & ER & $\begin{array}{l}\text { R-30 is planned to deepen borehole 49-2-700-1 in Aggregale } 3 \text { from the current depth of 700 ft to approximately } \\
1600 \mathrm{ft} \text {. This borehole will determine water qually in intermediale perched zones and in the regional aquifer } \\
\text { beneath MDA AB, which was used for underground hydronuclear experiments. }\end{array}$ \\
\hline
\end{tabular}




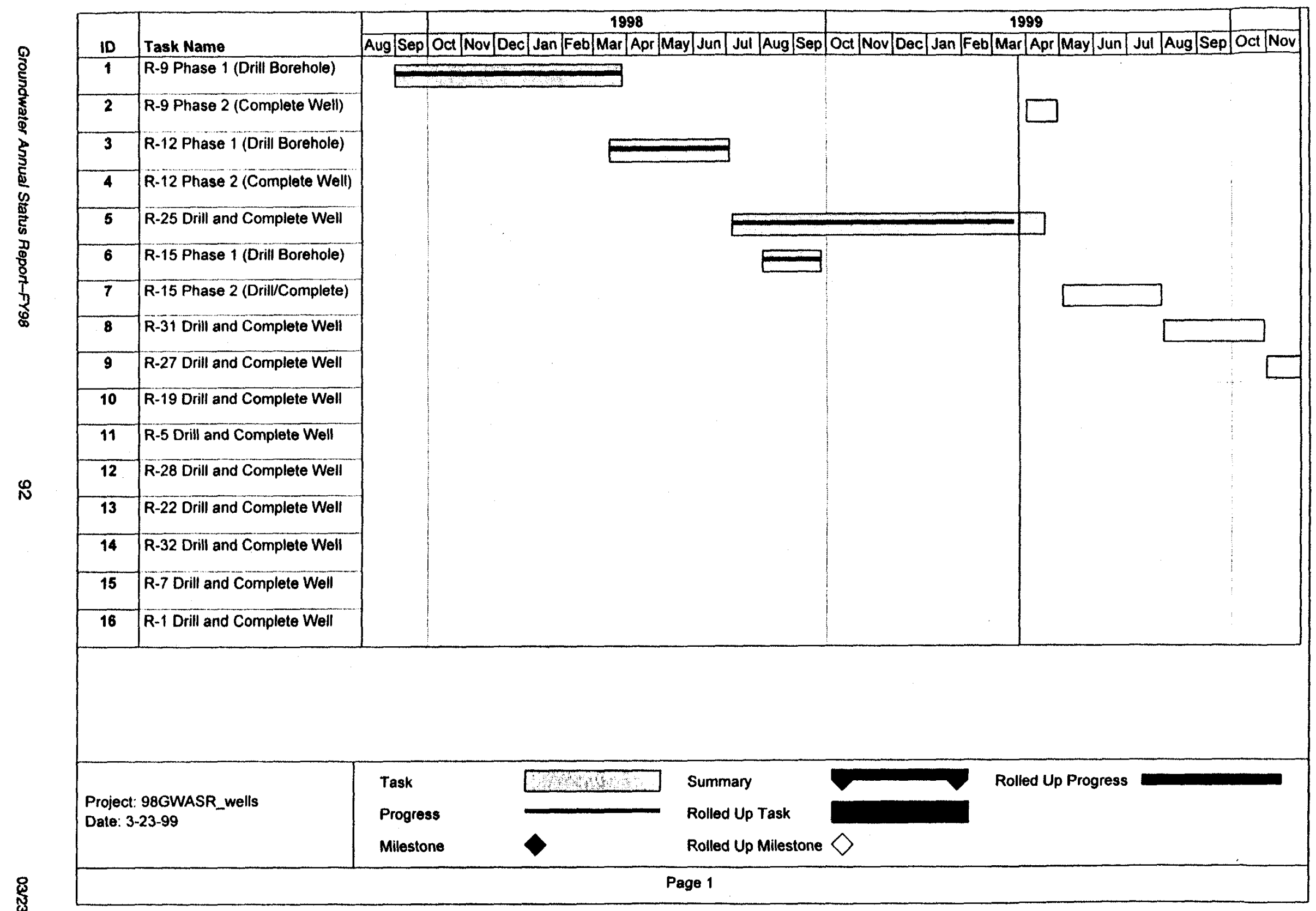

Figure 5.3-1. MWIP well completion schedule. 


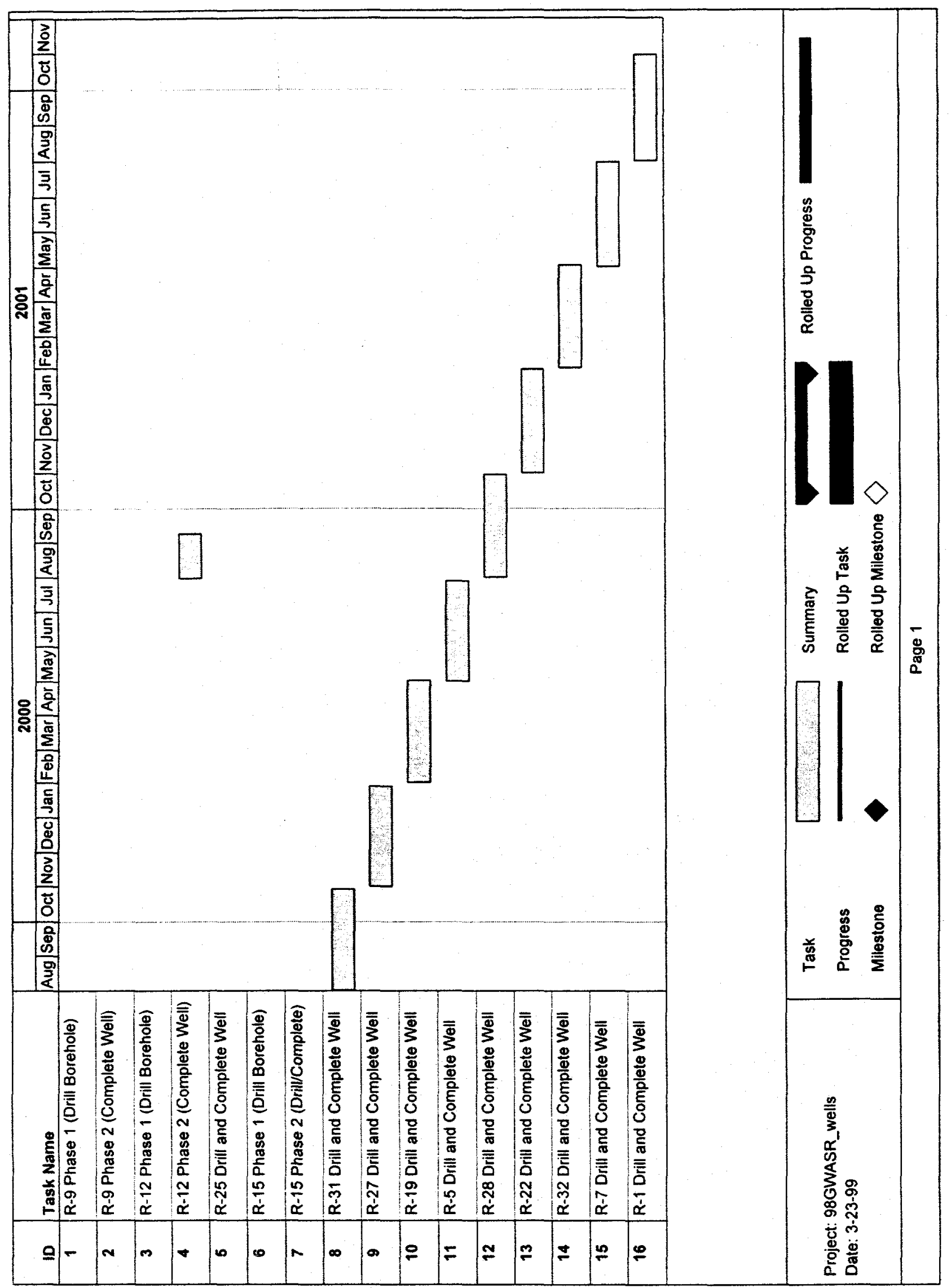

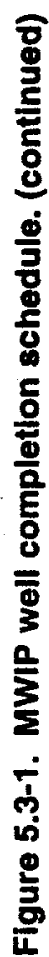




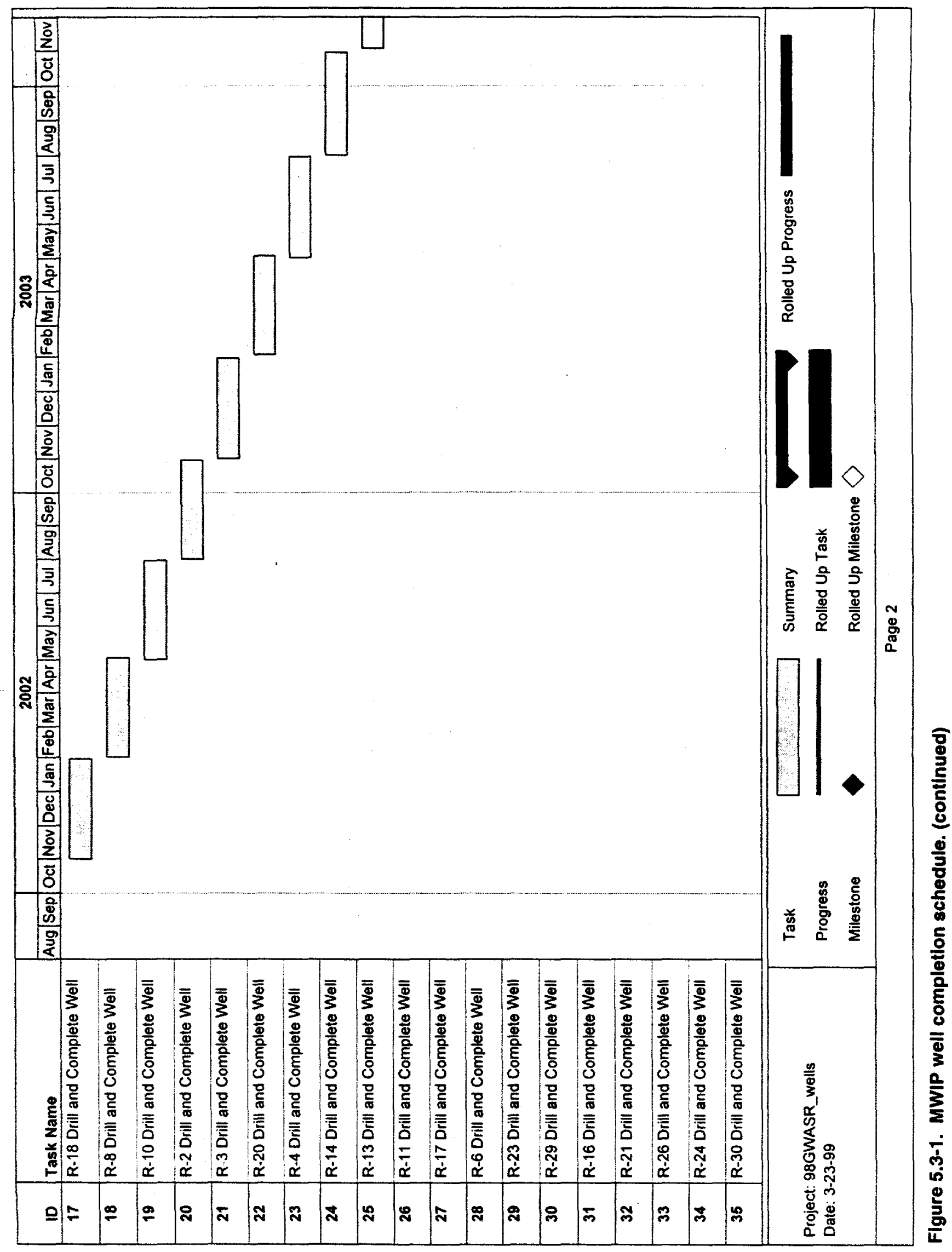




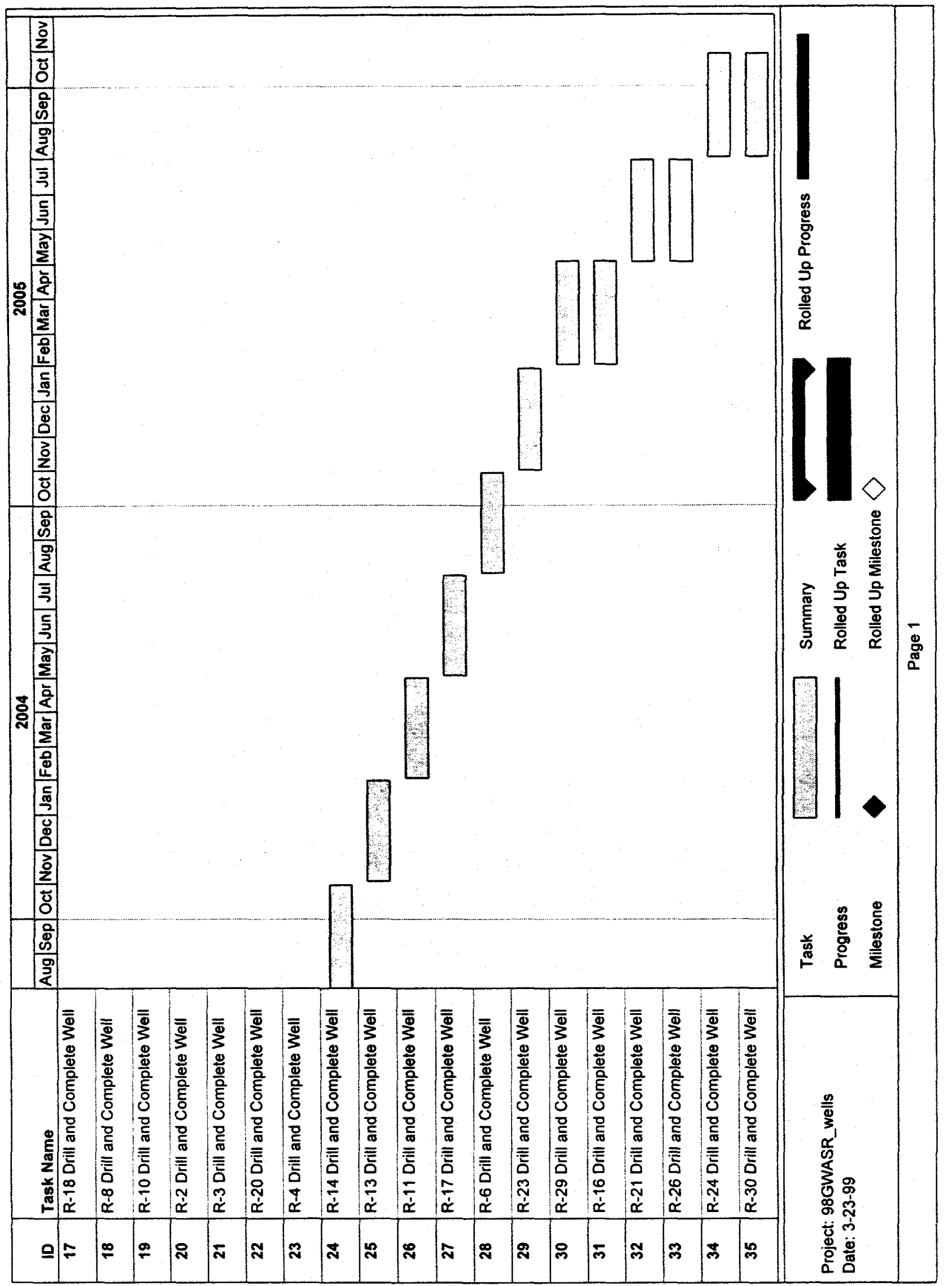

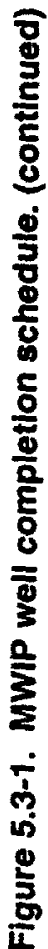




\subsection{REFERENCES}

Allison, J. D., D. S. Brown, and K. J. Novo-Gradac. 1991. "MINTEQA2/PRODEFA2, A Geochemical Assessment Model for Environmental Systems: Version 3.0 User's Manual." EPA600/3-91/021, Office of Research and Development, Athens, Georgia.

Broxton, D. E., R. Gilkeson, P. Longmire, J. Marin, R. Warren, A. Crowder, B. Newman, B. Lowry, D. Daymon, and D. Wycoft. 1998. "Interim Completion Report for Characterization Well R-9." Los Alamos National Laboratory Report LA-UR-98-3569. Los Alamos, New Mexico.

Broxton, D. E., R. Warren, A. Crowder, M. Everett, R. Gilkeson, P. Longmire, J. Marin. 1998a. "Interim Completion Report for Characterization Well R-12." Los Alamos National Laboratory Report LA-UR-98-3976. Los Alamos, New Mexico.

Cromack, K., Jr., P. Sollins, R. L. Todd, W. M. Fender, M. E. Crossley, and D. A. Crossley, Jr. 1977. "The role of oxalic acid and bicarbonate in calcium cycling by fungi and bacteria: Some possible implications for soil animals." Ecol. Bull. v. 25. pp. 246-252.

Dander, D. C. 1998. "Unsaturated Groundwater flow beneath Upper Mortandad Canyon, Los Alamos, New Mexico." Los Alamos National Laboratory Report LA-UR-98-4759. Los Alamos, New Mexico.

Dash, Z. V., B. A. Robinson, and G. A. Zyvoloski. 1997. "Software Requirements, Design, and Verification and Validation for the FEHM Application - A Finite Element Heat-and Mass-Transfer code." Los Alamos National Laboratory Report LA-13305-MS. Los Alamos, New Mexico.

Dethier, D. 1997. Geologic Map of the White Rock Quadrangle, Los Alamos and Santa Fe Counties, New Mexico. Map 73. Socorro: Bureau of Mines and Mineral Resources.

Drever, J. I. 1988. The Geochemistry of Natural Waters, 2nd Ed. New Jersey: Prentice Hall.

Fox, T. R. and Comerford N. B. 1990. "Low-Molecular-Weight Organic Acids in Selected Forest Soils of the Southeastem USA." Soil Sci. Soc. Am. v. 54. pp. 1139-1144.

Gray, R.N. 1998. "Report on Alluvial Well Completions 1996-1998." Los Alamos National Laboratory Report LA-UR-98-4047. Los Alamos, New Mexico.

Gray, R.N. 1997. "Hydrologic Budget Analysis and Numerical Simulations of Groundwater Flow in Los Alamos Canyon near Los Alamos, New Mexico." Master's Thesis, University of New Mexico.

Graustein, W. C., K. Cromack, Jr., and P. Sollins. 1977. "Calcium Oxalate: Occurrence in Soils and Effects on Nutrient and Geochemical Cycles." Science. v. 198. pp. 1252-1254.

Keating, E., G. Zyvoloski, C. Gable, M. Witkowski, K. Bower, and K. Manley. 1998. "A Steady-state Regional Flow Model for the Saturated Zone in the Española Basin." Los Alamos National Laboratory Report (In preparation).

Langmuir, D. 1997. Aqueous Environmental Geochemistry. New Jersey: Prentice Hall. 
LANL (Los Alamos National Laboratory). May 1998. "Hydrogeologic Workplan." Los Alamos, New Mexico.

LANL (Los Alamos National Laboratory). September 1998a. "RFI Report for Potential Release Site 16-021(c)." Los Alamos National Laboratory Report LA-UR-98-4101. Los Alamos, New Mexico.

LANL (Los Alamos National Laboratory). September 1998b. "CMS Plan for Potential Release Site 16-021 (c)." Los Alamos National Laboratory Report LA-UR-98-3918. Los Alamos, New Mexico.

LANL Los Alamos National Laboratory). September 1997. "Work Plan for Mortandad Canyon." Los Alamos National Laboratory Report LA-UR-97-3291. Los Alamos, New Mexico.

LANL (Los Alamos National Laboratory). January 1996. "Groundwater Protection Management Program Plan." Rev. 0.0. Los Alamos, New Mexico.

LANL (Los Alamos National Laboratory). 1947. "Chemistry of Uranium and Plutonium." Los Alamos National Laboratory Report LA-1100. Los Alamos, New Mexico.

LANL EEG (External Evaluation Group). 1998. "Semi-Annual Report, Groundwater Integration Team." Los Alamos, New Mexico.

MCDonald, M. G., and A. W. Harbaugh. 1988. "A Modular Three-dimensional Finite-difference Groundwater Flow Model. In: Techniques of Water-resources Investigations of the United States Geologic Survey. Book 6, Chapter A1: U.S. Geological Survey.

Newman, B. D. 1999. "Analytical Resuits and Data Interpretation for Oxalate and Other Anions from Vadose Zone Core Samples From TA-54, TA-21, and TA-49." Unpublished data. Los Alamos National Laboratory. Los Alamos, New Mexico.

Newman, B. D., A. R. Campbell, D. I. Norman, and D. B. Ringelberg. 1997. "A Model for Microbially Induced Precipitation of Vadose-zone Calcites in Fractures at Los Alamos, New Mexico, USA." Geochim. et Cosmo. Acta. v. 61, no. 9. pp. 1783-1792.

Newman, B. D. 1996. "Vadose Zone Water Movement at Area G, Los Alamos National Laboratory, TA-54: Interpretations Based on Chloride and Stable Isotope Profiles." Los Alamos National Laboratory Report LA-UR-96-4682. Los Alamos, New Mexico.

Newman, B. D., R. Gilkeson, and B. Gallaher. 1997. "Vadose Zone Water Movement at TA-49, Los Alamos National Laboratory: Interpretations Based on Chloride and Stable Isotope Profiles." Los Alamos National Laboratory Report LA-UR-97-3924. Los Alamos, New Mexico.

Nylander, C. L. 1999. "EEG Action Plan." Los Alamos National Laboratory. Los Alamos, New Mexico.

Reneau, S. L., and D. T. Vaniman. 1998. "Fracture Characteristics in a Disposal Pit on Mesita del Buey, Los Alamos National Laboratory." Los Alamos National Laboratory Report LA-13539-MS. Los Alamos, New Mexico.

Stauffer, P. H., and K. H. Birdsell. 1998. "Air Flow in a Fractured Mesa, Testing the Dry Barrier Hypothesis." Los Alamos National Laboratory Report (In preparation). Los Alamos, New Mexico. 
Thurman, E. M. 1985. Organic Geochemistry of Natural Waters. Dordrecht (Netherlands): Martinus Nijhoff/Dr W. Junk.

Trease, H., D. George, C. W. Gable, J. Fowler, A. Kuprat, and A. Khamyaseh. 1996. "The X3D Grid Generation System." In Numerical Grid Generation System in Computational Fluid Dynamics and Related Fields, B. K. Soni, J. F. Thompson, H. Hausser and P. R. Eiseman, eds. Boca Raton, Florida: CRC Press.

Zyvoloski, G. A., B. A. Robinson, Z. V. Dash, and L. L. Trease. 1996. Models and Methods Summary for the FEHM Application. Los Alamos National Laboratory YMP document FEHM MMS, ECD-22. 


\subsection{ANNUAL MEETING MINUTES AND ACTION ITEMS}

This section is provided as a placeholder for the meeting minutes and action items resulting from the annual stakeholder meeting scheduled in March of each year. These items will be distributed during the week following the annual meeting. 